\author{
UNIVERSIDADE DE SÃO PAULO \\ ESCOLA DE COMUNICAÇÃO E ARTES \\ Mestrado em Música
}

\title{
ASCENDÊNCIA RETÓRICA DAS FORMAS MUSICAIS
}

SÉRGIO EDUARDO MARTINELI DE ASSUMPÇÃO

SÃO PAULO

2007 


\section{UNIVERSIDADE DE SÃO PAULO \\ ESCOLA DE COMUNICAÇÃO E ARTES \\ Mestrado em Música}

\section{ASCENDÊNCIA RETÓRICA DAS FORMAS MUSICAIS}

SÉRGIO EDUARDO MARTINELI DE ASSUMPÇÃO

Dissertação apresentada junto ao Departamento de Música da Escola de Comunicações e Artes da Universidade de São Paulo, como exigência parcial para obtenção do grau de Mestre em Música, sob a orientação do Prof. Dr. Eduardo Henrique Soares Monteiro.

SÃO PAULO

2007 
Sérgio Eduardo Martineli de Assumpção

\section{ASCENDÊNCIA RETÓRICA DAS FORMAS MUSICAIS}

Banca Julgadora:

Prof. Dr. Eduardo Henrique Soares Monteiro 
A meus pais,

Deise e Augusto Caio,

fundamentais (em duplo sentido)

À Cláudia,

querida.

Aos professores que me formaram (em duplo sentido):

Orlando Marcos e

Aylton Escobar

A Ricardo Rizek, onipresença ausente, eternamente velado. 


\section{Agradecimentos}

Ao meu orientador, Prof. Dr. Eduardo Henrique Soares Monteiro, pela amizade, por acreditar neste trabalho e por torná-lo possível, sob todos os aspectos.

À Prof ${ }^{a}$ Dra. Mônica Isabel Lucas, pela disponibilidade e inestimável contribuição técnica e crítica.

À Prof ${ }^{a}$ Dra. Flávia Camargo Toni, pelo grande entusiasmo e pela contribuição metodológica.

Ao Prof.. Orlando Marcos Martins Mancini, pela amizade e ajuda incondicionais.

À Prof ${ }^{a}$ Deise Aparecida Martineli de Assumpção, pela revisão ortográfica e sugestões críticas.

Aos alunos com quem convivi nos últimos 12 anos e com os quais sempre aprendo admiravelmente mais. 


\section{CREDO UT INTELLIGAM}

(ANSELMO - TEÓLOGO MEDIEVAL) 


\section{RESUMO}

Esta pesquisa tem como objetivo investigar as influências e traços da retórica na gênese das formas musicais. Parte-se do pressuposto de que, a partir do desenvolvimento de uma música instrumental autônoma, emancipada da palavra, a herança retórica contribuiu para a disposição formal do material sonoro, bem como para harmonizar coerentemente as relações entre forma e conteúdo. O estudo propõe uma visão da retórica grega e latina contraposta à abordagem tradicionalmente sistemática das formas musicais. Ambas são, então, relacionadas por meio dos conceitos retóricomusicais, estabelecidos e codificados preponderantemente no século XVIII, em consonância com a fundamentação aristotélica. Esta intersecção permite uma reavaliação das práticas analíticas, enriquecendo-as a partir da introdução da metáfora da oração e da função persuasiva que integram o processo composicional. Vislumbra-se, por tais procedimentos, a reavaliação das possibilidades semânticas ocultas pela codificação sintática.

Palavras-chave: música, retórica, formas musicais, análise musical, filosofia. 


\begin{abstract}
This research aims to investigate the influences and traces of rhetoric in the genesis of the musical forms. It is based on the assumption that, starting from the development of an autonomous instrumental music, emancipated from the word, the rhetoric inheritance contributed for the formal disposition of sonorous material, as well to harmonize coherently the relation between structure and content. The study proposes a vision of Greek and Latin rhetoric as compared to the traditionally systematic approach of the musical forms. Both are, then, related through rhetoric-musical concepts, established and codified predominantly in the eighteenth century, in consonance with the Aristotelic bases. This intersection permits a re-evaluation of the analytical practices, enriching them with the introduction of the metaphor of the oration and by the persuasive function that integrates the compositional process. One gains a glimpse, that through such procedures, of the re-evaluation of the semantical possibilities hidden by the syntactic codification.
\end{abstract}

Keywords: music, rhetoric, musical forms, musical analysis, philosophy. 


\section{SUMÁRIO}

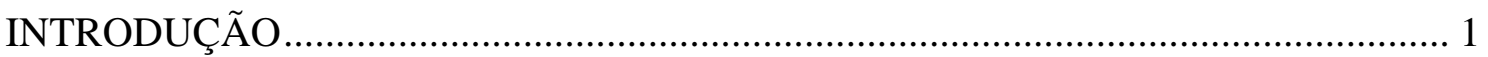

CAPÍTULO 1 - RETÓRICA ….......................................................................... 4

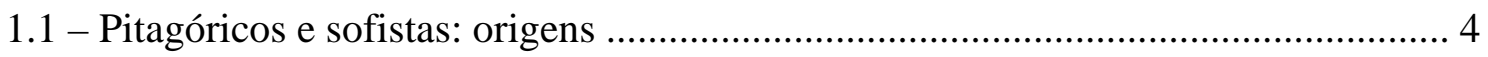

1.1.1 - A retórica do verossímil e a corrente psicagógica ........................................ 4

1.1.2 - Uma pitada pitagórica ......................................................................... 5

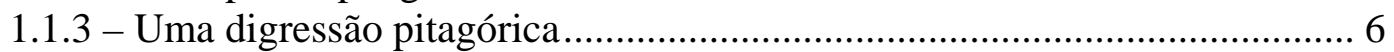

1.1.4 - Sofistas: Protágoras e Górgias ............................................................. 7

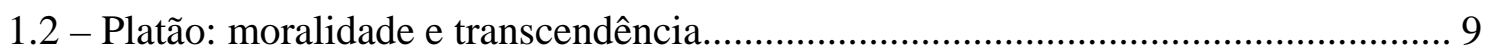

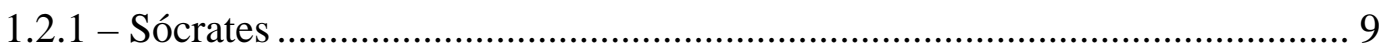

1.2.2 - A retórica como empeiria: implicações morais ........................................ 10

1.2 .3 - A depuração dialética .......................................................................... 12

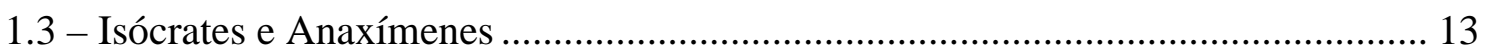

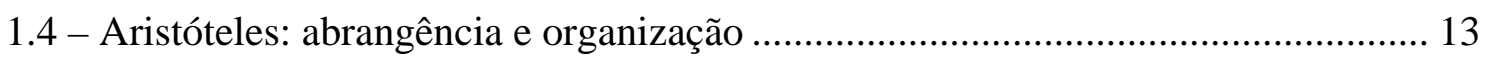

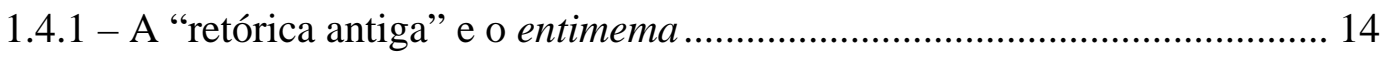

1.4.2 - A "retórica recente" e o papel das paixões .............................................. 15

1.4.3 - Os tópoi ou "lugares” retóricos ..................................................................... 17

1.4.4 - O estilo e as divisões do discurso............................................................. 18

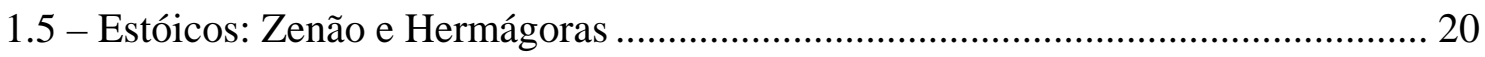

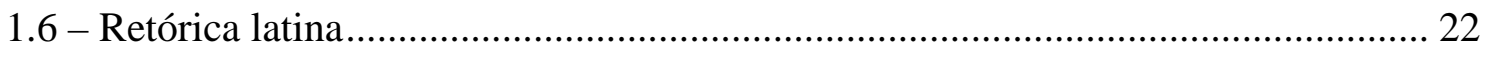

1.6.1 - A Rhetorica ad Herennium .................................................................... 22

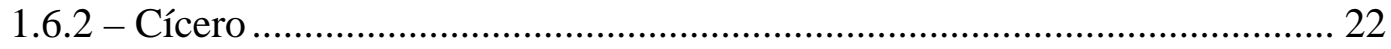

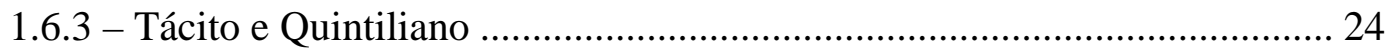

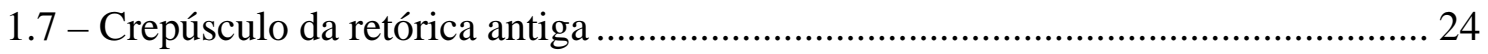

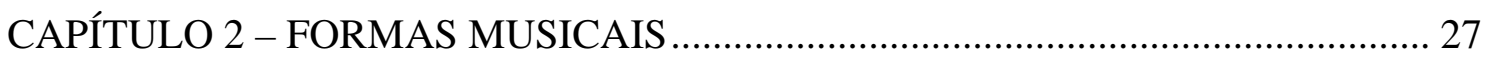

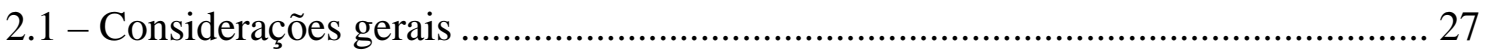

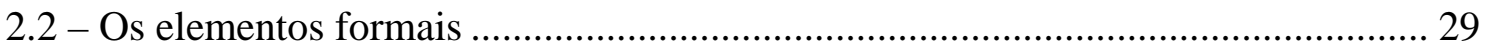




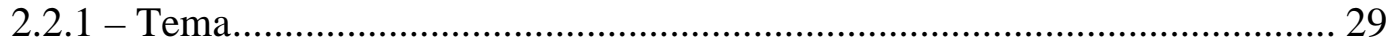

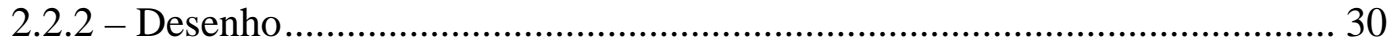

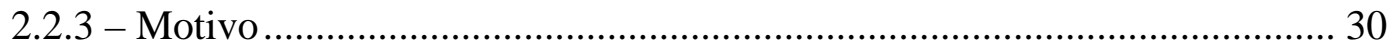

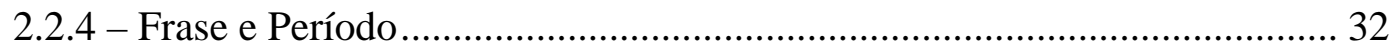

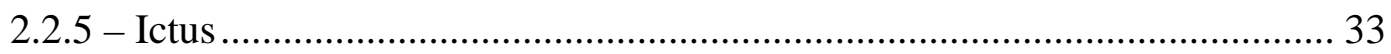

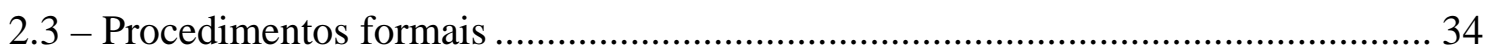

2.3.1 - Considerações harmônicas ................................................................. 34

2.3.2 - Considerações fraseológicas ............................................................. 35

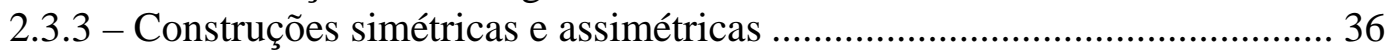

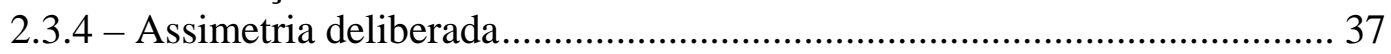

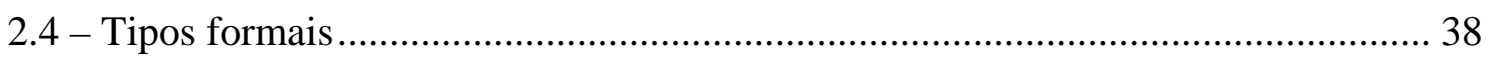

2.4.1 - Formas binária simples e ternária simples ................................................ 39

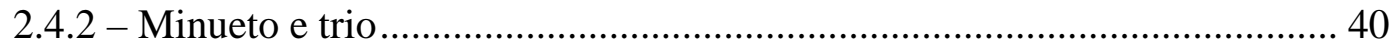

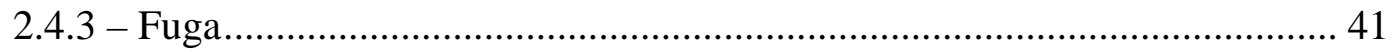

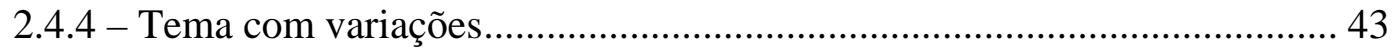

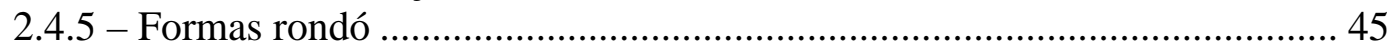

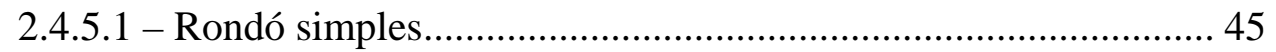

2.4.5.2 - Forma lied ................................................................................ 46

2.4.5.3 - Rondó sonata........................................................................... 47

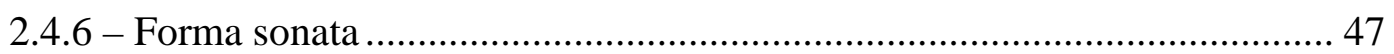

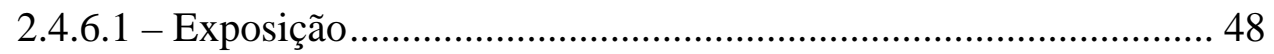

2.4.6.2 - Elaboração ou desenvolvimento ............................................. 49

2.4.6.3 - Reexposição ou recapitulação.................................................. 50

CAPÍTULO 3 - RETÓRICA MUSICAL .................................................................... 52

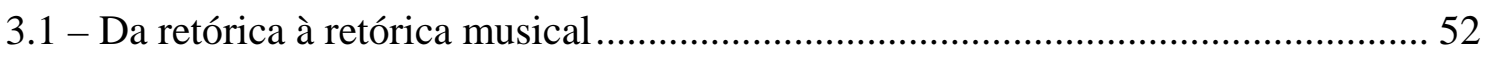

3.2 - As septem artes liberales: trivium e quadrivium .............................................. 54

3.3 - Música poética e os tratados: ars compositionis ............................................... 56

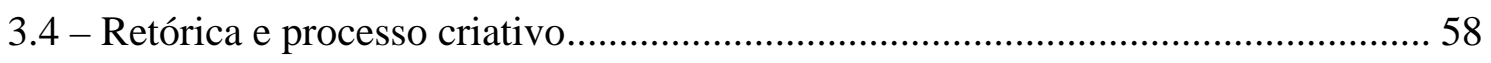

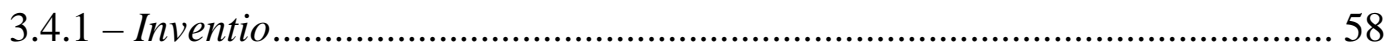

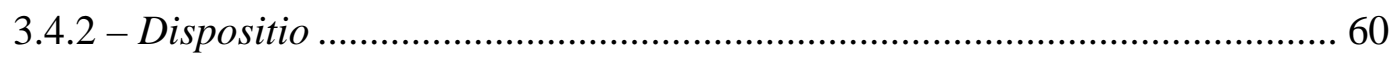

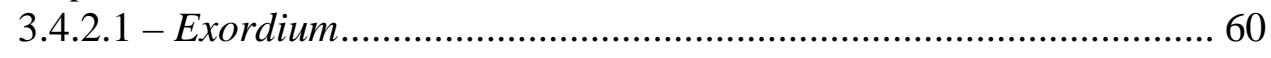

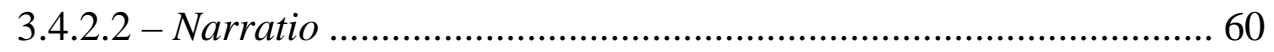

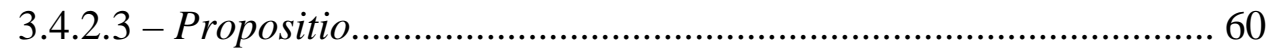

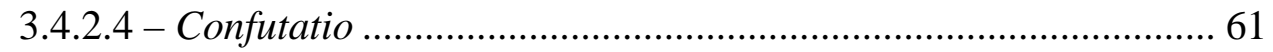

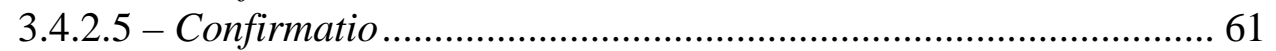

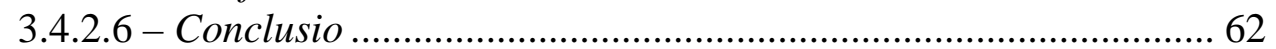

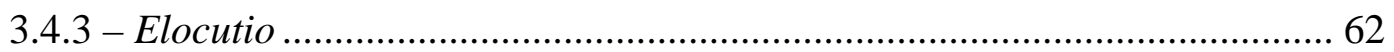

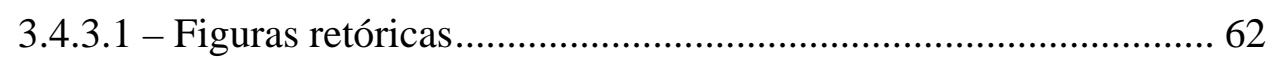

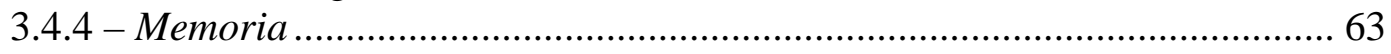

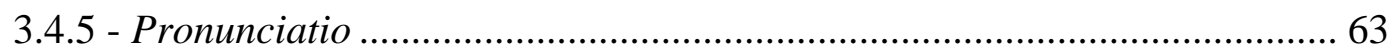


3.5 - Forma Musical e Retórica

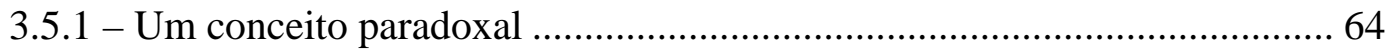

3.5.2 - Sonata como forma e como procedimento ................................................. 68

3.5.3 - Plano harmônico e plano temático na forma sonata .................................. 70

3.5.4 - Bipartição e tripartição na forma sonata ................................................ 72

3.5.5 - Orientação pragmática e orientação expressiva ..................................... 74

3.5.6 - Música instrumental: oração sem palavras ............................................. 77

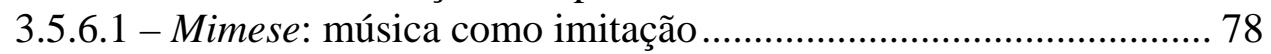

3.5.7 - Gramática musical e retórica: limites....................................................... 84

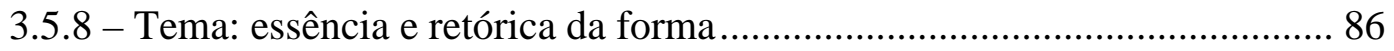

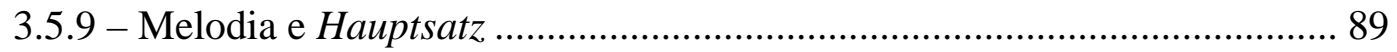

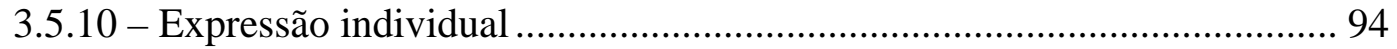

3.5.11 - A metáfora do organismo e o declínio da retórica .................................. 95

3.6 - Análise do $1^{\circ}$ movimento da Sonata nº 8 em dó menor, opus 13, - “Patética” - L.

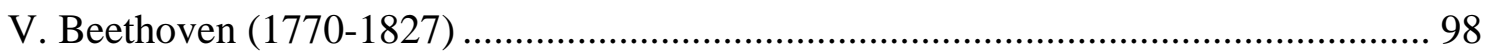

3.6.1 - Introdução (exordium): compassos 1-10 ................................................ 98

3.6.2 - Exposição (propositio): compassos 11-132 .............................................. 100

3.6.3 - Introdução (exordium) intercalada: compassos 133-136 ....................... 105

3.6.4 - Desenvolvimento ou elaboração (confutatio): compassos 137-194........ 105

3.6.5 - Reexposição (confirmatio): compassos 195-310 ….................................. 109

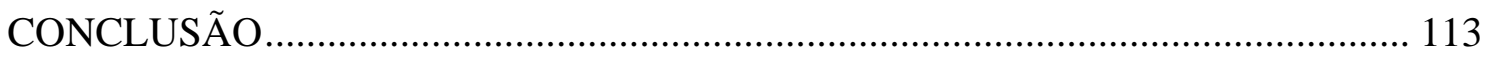

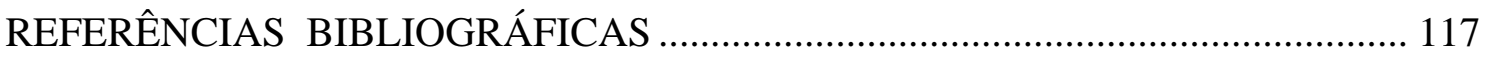

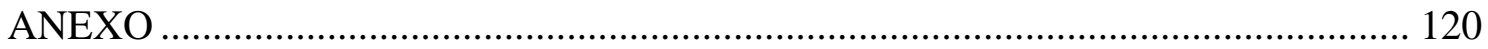




\section{ÍNDICE DE FIGURAS}

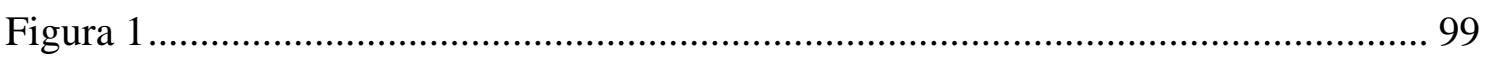

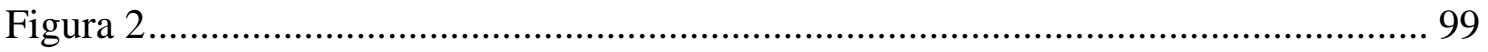

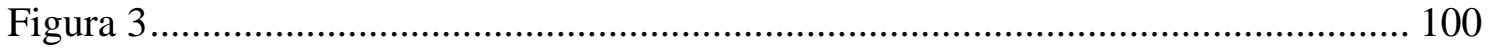

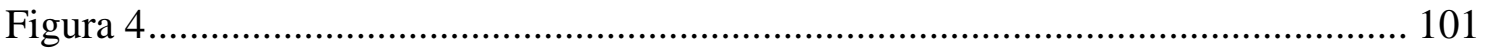

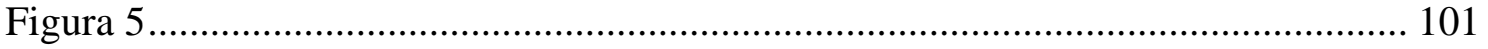

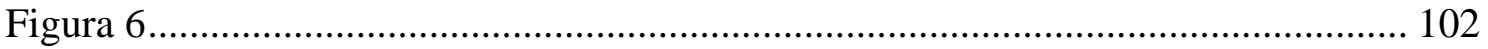

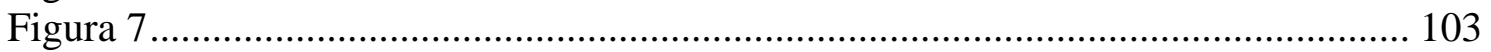

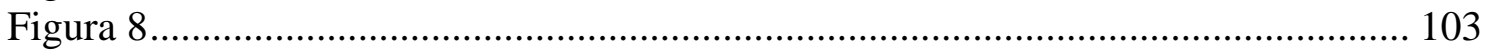

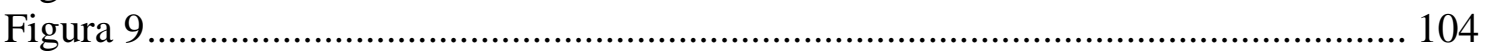

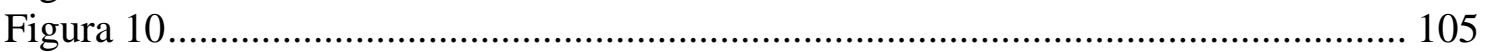

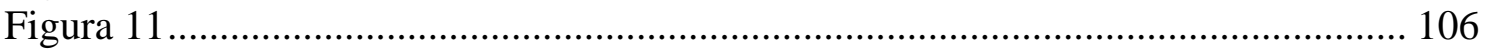

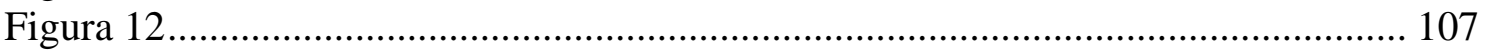

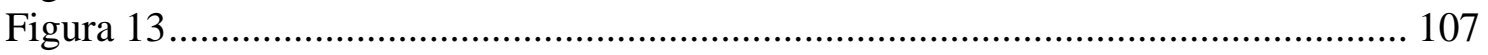

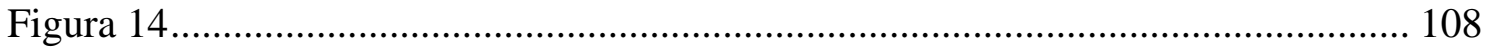

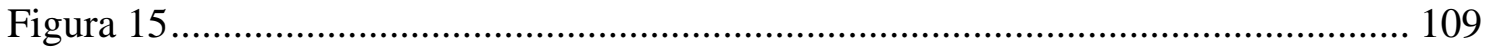

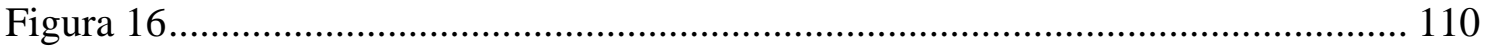

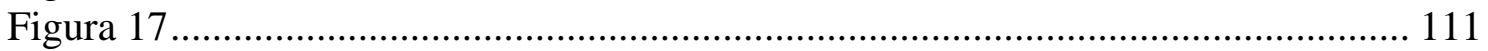

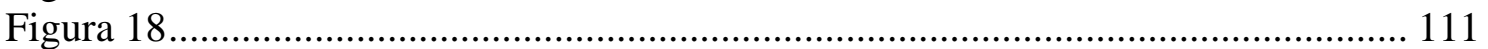

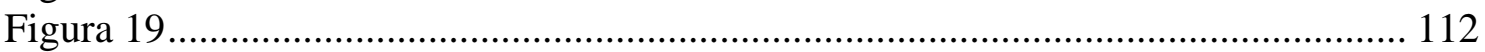




\section{Introdução}

O estudo da teoria musical tem, como pressuposto, a aceitação tácita da necessidade do conhecimento e reconhecimento da gramática para a correta utilização da linguagem musical. As auspiciosas especulações que este estudo adicionalmente pode fomentar, contudo, não poucas vezes são tidas como extrínsecas ao processo musical em si, especialmente quando talhadas à luz da filosofia e da estética; e, uma vez apartadas da música, tais especulações tendem a ser desvalorizadas pelo próprio músico.

Assim, o estudo da harmonia, do contraponto e das formas musicais, enquanto subsídio para a composição, a interpretação e a análise musical, geralmente assume duas formas: ou é compreendido como parte integrante da formação musical, qualquer que seja a área de atuação pretendida, ou é tido como um estudo preliminar, deveras entediante, que deve logo ser transposto.

Na gênese da opção (ainda que inconsciente) por uma das vias acima delineadas, figuram a maneira como a tradição gramatical musical nos foi apresentada, as intersecções que se fizeram entre esta tradição e a "prática” musical, e ainda certa inclinação particular para com a especulação filosófica, provavelmente devida à bagagem educacional e intelectual presente em nossa formação. Em outras palavras, são necessários uma boa semente, um bom jardineiro e uma boa terra.

O conhecimento não se faz apenas de especificidades, mas também de conexões virtuosas entre especificidades. É do eterno ciclo de alternâncias entre a necessária aderência “cega” a uma especificidade e seu confrontamento com a totalidade já adquirida que o conhecimento frutifica. Assim como a matemática e a música estão virtualmente unidas, também a filosofia e a música o estão, mas enquanto a primeira união goza de prestígio quase unânime, a segunda eventualmente é palco de suspeita.

Nobres e elevados pensamentos, expressos em linguagem verbal (grafada ou não), especialmente quando traduzem certa ânsia metafísica, são atribuídos a filósofos. Não menos nobres e elevados, os pensamentos musicais, cujas qualidades transcendentes estão isentas de dissensões, são emanados do compositor. Aceita a metáfora da linguagem, a música habita a intersecção entre poesia, prosa e filosofia. Sobre elas, por elas e com elas, impõe suas especificidades. 
O século XVIII, ao enfrentar o problema da organização formal de uma música puramente instrumental em plena ascensão, recorreu à filosofia grega, mais especificamente à retórica, para alicerçar critérios. Não tendo mais a palavra a orientar seu discurso musical, apoiou-se sobre a organização discursiva que a própria palavra houvera construído. Com a emancipação da música da palavra, o material musical requereu para si a prerrogativa de uma organização própria, vale dizer, a partir de suas especificidades.

Os protótipos formais nascidos desta emancipação percorreram toda a tradição tonal a partir de meados do século XVIII, cruzando inclusive as fronteiras do século XX, e impondo-se como parâmetros até para os materiais vanguardistas.

As abordagens retóricas em música, entretanto, destacam-se por guardarem um segredo: veicular uma semântica que supostamente seria adjacente à sintaxe musical, com especial atenção ao papel das figuras retóricas. Também a interpretação musical tem se nutrido em fontes retóricas, especialmente para melhor entender (e interpretar) a música do barroco e do classicismo.

Curiosamente, os tratados de formas musicais (pelo menos até meados do século XX) são econômicos em citar o termo "retórica” ao orientar suas premissas, embora todo o vocabulário utilizado seja derivado da metáfora lingüística: período, frase, motivo, sujeito, tema, sentença e outros. Com raras exceções, esse "esquecimento" se verifica, e deve-se provavelmente ao preconceito que permeou a segunda metade do século XIX e a primeira do século XX, preconceito segundo o qual citar a metáfora da linguagem seria remeter-se a algo historicamente superado, relíquia de um passado distante e atrasado.

Ao observarmos, entretanto, o processo de criação e elaboração do discurso que a oratória depurou ao longo do tempo, imediatas transposições remetem-nos à criação musical e sua organização formal. Paralelos entre as partes da dispositio e a forma sonata são por demais evidentes para serem desprezados, e foram citados nas fontes do século XVIII. Com o declínio da retórica, tais elos se perderam ou foram omitidos.

A retórica, contudo, possui mais a oferecer além das reminiscências semânticas ocultas nas figuras retóricas ou de um preceituário formal sob o qual as idéias devam dispor-se. Retórica é disciplina privilegiada para especulações sobre as relações entre forma e conteúdo, fornecendo preciosos instrumentos para uma conceituação mais abrangente. 
O aprofundamento das discussões entre forma e conteúdo que a retórica promove é valioso àqueles que se dedicam à composição e à análise musical, e tais debates vêm se constituindo em recorrente assunto da estética do século XX, não apenas no que se refere à música. Para toda a arte, bem como para toda abordagem didática que a arte prescreve, tal debate tem sua validade insistentemente reiterada.

Nosso estudo parte de um pressuposto: o de que a criação dos tipos formais musicais originou-se e foi assentada sobre bases retóricas, mesmo quando posteriormente ratificamos a organização dos materiais musicais a partir de suas próprias especificidades. Não se trata de ocultar as especificidades da música, nem de advogar a favor de uma dependência da música ou da teoria das formas musicais para com a retórica. O que vislumbramos aqui e pretendemos revelar é a gênese retórica das formas musicais, historicamente amparada pelas reminiscências que tal ancestralidade providencialmente registrou no próprio material musical.

Iniciaremos com o estudo da retórica, codificando a cronologia de seu desenvolvimento e delimitando os maiores desafios por ela enfrentados: um platônico debate ético acerca de sua natureza e sua aristotélica codificação num corpo de preceitos conseqüentemente coordenados.

Abruptamente abandonaremos a retórica para mergulharmos no estudo das formas musicais, a partir de quatro autores reconhecidos como grandes autoridades no assunto: Hugo Riemann, Joaquin Zamacois, Giulio Bas e Arnold Schoenberg. Com esta metodologia, intentamos transportar o leitor ao ponto exato em que um músico, tendo se dedicado à sistemática das formas musicais e, simultaneamente, à história da retórica antiga, houvesse por bem relacioná-las, criando intuitivamente uma particular retórica musical.

Nosso terceiro e mais longo capítulo percorrerá o roteiro conjuntamente realizado por música e retórica, dando especial ênfase à função retórica da forma musical. Tal ênfase está amplamente alicerçada nos estudos de Mark Evan Bonds. Uma análise formal do primeiro movimento da Sonata $\mathrm{n}^{\circ}$ 8, opus 13, de Beethoven (“Patética”), encerra nosso estudo.

Cumpramos, pois, nosso roteiro. 


\section{Capítulo 1 - Retórica}

Do grego rhetoriké e de seu correspondente latino rhetorica, é a arte da eloqüência e do bem dizer, arte da oratória e, por extensão, também o conjunto de regras que constituem e organizam essa arte (HOUAISS, 2001, p. 2447).

A retórica teve seu apogeu na Antigüidade grega e latina, sendo na Idade Média absorvida no trivium como uma de suas disciplinas, ao lado da gramática e da lógica. Já o quadrivium abrangia a aritmética, a geometria, a música e a astronomia. Unidos, trivium e quadrivium perfaziam as sete artes liberais ministradas no ensino universitário (HOUAISS, 2001, p. 2344/2773).

\section{1 - Pitagóricos e sofistas: origens}

\subsection{1 - A retórica do verossímil e a corrente psicagógica}

Na Magna Grécia do século V a.C. encontramos as origens da retórica antiga, tendo em Córax e Tísias os primeiros retóricos de que se tem notícia. Sobre suas vidas pouco sabemos, apenas que viveram durante o referido século e que, segundo o testemunho de Cícero, embora a prática retórica fosse presente de há muito, estes dois sicilianos lhes deram método e regras (PLEBE, 1978, p. 1-2). Por conseguinte, podemos supor que se fazia necessária uma organização na maneira de argumentar. No diálogo intitulado Fedro, Platão (427 - 347 a.C.) nos ensina que o fundamento filosófico da retórica de Tísias (e, por extensão, também a de Córax, seu mestre) era a procura do “verossímil” (PLATÃO, s.d.[b], p. 177). Teses dadas deveriam ser apresentadas por técnicas de demonstração da verossimilhança, de características probatórias. O “verossímil” não se constituía do que pudesse ser evidente aos sentidos, mas do que pudesse ser demonstrado à razão, através de argumentos. Como outras razões, de alcance mais amplo, posteriormente poderiam vir a alterar a noção do objeto estudado, o “verossímil” não se constituía em verdade absoluta. Mais estimável até que o verdadeiro, o “verossímil” alcançou ampla repercussão na época e foi, obviamente, 
contestado, especialmente por seu suposto rigor técnico e racional que, por vezes, mostrava-se impotente para explicar diversas questões a contento.

Em contrapartida à demonstração técnica do verossímil, surgiu uma retórica menos científica, "fundada na sedução irracional que a palavra, sabiamente usada, exerce sobre a alma dos ouvintes.”(PLEBE, 1978, p.3) Por “irracional” deve-se compreender, neste contexto, não o que está aquém da razão e a contradiz, mas o que pretende estar além dela, superando-a, baseado na própria percepção da impotência da razão, no estágio em que se encontra, em abarcar o assunto em pauta.

Esta corrente, dita psicagógica, tinha suas raízes ligadas ao pitagorismo, e duas são suas características principais: a adaptação do estilo e do argumento ao tipo de ouvinte a quem se dirige o discurso, e o emprego constante da antítese como figura retórica. Tanto a variação do discurso, apoiada na faculdade de encontrar os meios de expressão convenientes a cada situação (chamada polytropia), quanto a utilização da antítese (justificada pelo fato de que o belo participa do feio, e o justo do injusto) tinham por finalidade antes estimular as reações psicológicas do ouvinte do que convencê-lo racionalmente. E mais: esta teoria psicagógica da retórica encontrava eco em Parmênides (c.530 - 460 a.C.), que distinguia o mundo da verdade, caracterizado pelo raciocínio científico, do mundo da doxa (opinião), sujeito ao fascínio da palavra (distinção esta também presente nas correntes pitagóricas). É a retórica do irracional, que seria depois atribuída ao místico e pitagórico Empédocles (c.490 - 435 a.C.) por Aristóteles que, aliás, o teve por inventor da retórica (PLEBE, 1978, p. 3-5)

Etimologicamente, psicagogia significa “evocação das almas dos mortos” e, com efeito, na Grécia antiga havia uma cerimônia de invocação de almas que atendia exatamente pelo nome de psicagogia (HOUAISS, 2001, p. 2325). Por este viés, o significado do termo psicagogia abarca, portanto, uma evocação de amplitudes metafísicas.

\subsection{2 - Uma pitada pitagórica}

A retórica do irracional comungava preceitos comuns à magia e à medicina da época, visto ambas serem também polytropos: lidavam com diferentes enfermidades e enfermos, adequando-se aos diversos casos. E havia, para os pitagóricos, uma arte terapêutica por excelência: a música. Uma força mágica atuava nos homens através da música, e Pitágoras (569?-470? a.C.) imaginava “combinações de certos cantos 
diatônicos, cromáticos e enarmônicos, por meio dos quais facilmente se anulavam e se desviavam, em sentidos opostos, as paixões da alma." (JÂMBLICO apud PLEBE, 1978, p. 5) As relações entre retórica e música já se faziam então presentes, pois, para os pitagóricos, a "eloqüência é enganadora, assim como a música é encantamento, porque ambas não são ciências demonstrativas, mas artes médico-mágicas, cuja essência reside propriamente na força de uma persuasão psicológica irracional.” (PLEBE, 1978, p. 6)

À teoria pitagórica do discurso polytropos liga-se a doutrina do kairós retórico. O kairós é um conceito de proporcionalidade (numérico, harmônico, portanto pitagórico), que aplica o conceito de “oportunidade” aos testemunhos. Assim sendo, há uma justiça proporcional, não exatamente igual para todos, mas atribuída a cada um segundo seu direito particular. Segundo as circunstâncias e as pessoas envolvidas, os julgamentos levam em consideração determinadas questões sob maior ou menor interesse, de maneira que há uma proporcionalidade inerente em cada caso, dita oportuna, e que se manifesta na aceitação de proposições pelo senso comum. Essa proporcionalidade é obtida se, ao conceito de justiça, se conjuga o kairós. E a própria harmonia também participa, para os pitagóricos, da faculdade de escolher palavras adequadas ao discurso pontual, o que significa que harmonia e proporção não podem ser dissociadas. A dimensão da importância dessa proporcionalidade pode ser aferida pela maneira como o número era conceitualizado pelos pitagóricos.

\subsection{3 - Uma digressão pitagórica}

Graças aos escritos de Mário Ferreira dos Santos, podemos aprender que o movimento pitagórico, organizado em forma de comunidade, contendo ritos iniciáticos e extensa simbologia, teve caráter abrangente, com implicações intelectuais, morais, religiosas e políticas. A escola de Crótona, fundada por Pitágoras em cerca de 530 a.C., pregava rígida doutrina de preceituário moral, estando aí inclusos métodos de purificação reservados aos iniciados. O século VI a.C., não por acaso, é também o século de Gautama Buda, Zoroastro ou Zaratustra, Confúcio e Lau-Tsê.

Devemos supostamente a Pitágoras e/ou aos pitagóricos (porque não há como provar a proveniência de tais assuntos) a introdução de diversos temas no seio do pensamento humano, tais como: a transmigração das almas (ou metempsicose); o eterno retorno dos acontecimentos já acontecidos; a alma como princípio do movimento; o conceito de Cosmos como ordem universal, em oposição a Caos (ausência de ordem); a 
harmonia como a unidade do múltiplo, acordo entre discordantes; o número como essência das coisas. A Pitágoras é ainda atribuído o primeiro emprego da palavra “filósofo”, já como estudioso da sabedoria (SANTOS, 2000, 61-64).

Para o pitagorismo, tudo são números: geometria é o número espacialmente proporcionado, música é o número acusticamente manifestado, cálculo é o número em sua abstração pura. O número, portanto, não se reduzia a mero símbolo gráfico a representar as quantidades, mas era portador de um aspecto qualitativo, de uma essência onipresente mas oculta, de uma permanência que a tudo permeia desde dentro e desde sempre. Ao número é intrínseco um valor ontológico.

O poder mágico do número encontra ressonância junto ao poder mítico da palavra. E se, ao fundamentar as matérias quantitativas, o número haveria de abandonar sua prerrogativa ontológica para cumprir uma função didática, mesmo caminho descensional seria traçado pela palavra, ao abdicar de sua força transcendente e, dobrando-se à lógica, procurar fazer-se razoável, para que persuasiva.

\subsection{4 - Sofistas: Protágoras e Górgias}

Foi Protágoras de Abdera (ca. 490-421 a.C.) quem trouxe à Grécia continental as principais correntes retóricas supracitadas e as reelaborou de maneira bastante particular. As antíteses, por exemplo, reaparecem como teorias do “discurso duplo”, nas Antilogias; o kairós ganha contornos menos moralistas. Protágoras defendia que dois discursos reciprocamente opostos poderiam ser conduzidos diante de qualquer questão, e teria ensinado seus alunos a louvar e a censurar um mesmo homem. Esses discursos duplos originam a "técnica da contradição", fundamento da retórica sofística (PLEBE, 1978, 9-10). Os sofistas eram mestres da eloqüência, famosos na Grécia dos séculos V e IV a.C. por envolverem-se em acirradas disputas filosóficas, religiosas e políticas. Protágoras e Górgias são dois dos importantes representantes da retórica sofística, que será duramente combatida por Platão, sob o argumento da ausência de moralidade que lhe seria subjacente, como logo veremos.

A despeito da importância de Protágoras, é com Górgias de Leontinos (ca. 487380 a.C.) que a formalização de uma arte retórica como disciplina independente ganha vida. Nascido siciliano, este aluno de Empédocles (490?-435? a.C.) passou a maior parte de sua vida em Atenas, tendo lá chegado em 427 a.C., coincidentemente o ano do nascimento de Platão, este que mais tarde lhe outorgaria fama em um de seus diálogos. 
Górgias focou primordialmente a eficácia do logos, do discurso, classificando poesia e prosa apenas como discursos com e sem metro, respectivamente, o que os aproximava. A poesia é caracterizada como engano, ilusão, mas uma doce ilusão que embala os que aceitam ser por ela enganados (Ibidem, p. 12). Engano não tem aqui conotação pejorativa, mas unicamente significa o que escapa à realidade. É importante notar que o encantamento poético em Górgias não possui o caráter terapêutico do pitagorismo, mas aceita o desvio operado nos sentidos pelo arrebatamento poético como exercício para a sensibilidade da alma. Já a prosa apóia-se na persuasão retórica, que arrasta à ação, mas que fomenta mais uma crença que um ensinamento. Portanto ambas, poesia e prosa, unem-se sob um conceito único, que bem pode ser o da psicagogia: a poesia faz crer no que não existe, a persuasão retórica (prosa) faz crer que as coisas são diferentes do que são, conforme as intenções do orador.

Górgias, no Elogio de Helena, subdivide os discursos em três gêneros principais: os escritos dos meteorologistas (filósofos naturalistas), os discursos públicos (nos tribunais e assembléias populares) e as disputas filosóficas. Os dois últimos gêneros serão, para toda a Antigüidade, o centro de toda a tradição retórica, influenciando decisivamente os escritos de Aristóteles. Particularmente o último, o das disputas filosóficas, terá proeminência nas discussões platônicas, nas quais o interesse dialético-retórico predominará (Ibidem, p.16).

Além dos gêneros, Górgias também distinguiu as formas fundamentais pelas quais o estilo realiza seus objetivos, as figuras retóricas. As principais delas eram a isocolia (que se refere ao período composto de membros iguais), a parisosis (que diz respeito à correspondência de sons ou de membros de frases semelhantes), o homoteleuto (que diz respeito à similitude nas terminações de dois ou mais membros de frase consecutivos) e a antítese (oposição de idéias ou palavras). É Plutarco (ca. 46-120 d.C.) quem nos lega a definição mais ampla da retórica gorgiana:

A retórica é a arte relativa aos discursos, que tem a sua força no ser artífice de uma persuasão nos discursos políticos sobre todos os assuntos, arte criadora de uma crença e não de ensinamentos; os seus argumentos próprios dizem respeito sobretudo ao justo e ao injusto, ao bem e ao mal, ao belo e ao feio. (PLUTARCO apud PLEBE, 1978, p. 17) 


\section{2 - Platão: moralidade e transcendência}

\subsection{1 - Sócrates}

Grande foi o êxito alcançado pela retórica gorgiana, e o próprio Sócrates (470399 a.C.) pode ser considerado um retórico sofista, embora num grau acentuadamente mais elevado (já distante das inúmeras vicissitudes dos sofistas atenienses, que cobravam por seus ensinamentos). Embora Platão tenha se esforçado em apresentá-lo sempre como adversário dos sofistas e dos retores (outra denominação dada aos retóricos), é inegável que Sócrates tenha professado, ainda que de forma extremamente pessoal, a téchne rhetoriké, a arte retórica. Esta maneira própria de professar a retórica manifestava-se em não apressar-se em instruir seus discípulos na arte de bem falar, conquanto não houvessem sido já tangidos à trilha da sabedoria, pela busca obstinada do autoconhecimento. Platão viu-se, neste contexto, diante da necessidade de explicitar as relações entre retórica e filosofia e, ainda, de adequar o discurso socrático a suas finalidades pedagógicas. Isso poderia justificar, em parte, a insistência na polêmica sobre a retórica, presente nos primeiros diálogos platônicos. Com efeito, é precisamente nestes pontos que residem as mais agudas dúvidas sobre a autenticidade do Sócrates platônico.

Expliquemo-nos: quer nos parecer que seria Platão, mais do que Sócrates, quem se opunha à sofística. Sabendo que tudo o que nos chegou como conceitos provenientes de Sócrates nos foi legado pela pena de Platão, é voz comum entre os estudiosos que algo do que Sócrates professa pode ser acréscimo platônico. O que realmente é pensamento socrático e o que se prefigura como intervenção platônica não pode ser claramente determinado. Entretanto, é preciso cuidar para que, dessa observação, não se deduza uma generalização, provavelmente injusta, que possa diminuir a grandeza e os méritos da obra platônica. Muito menos trata-se de julgar que não temos diante de nós um Sócrates razoavelmente verdadeiro, ou que o temos deveras distorcido. Platão foi, acima de tudo, um discípulo e um admirador do mestre, e sua obra manifesta a qualidade de seu caráter e a profundidade de sua inteligência. 


\subsection{2 - A retórica como empeiria: implicações morais}

Não por acaso, é no diálogo platônico intitulado Górgias que encontraremos as principais distinções entre o pensamento gorgiano e o platônico (via Sócrates) acerca da retórica. Que a retórica não fosse uma ciência já era aceito pelo senso comum da época, entretanto, que ela não mereceria nem o status de arte (téchne rhetoriké) era o que Platão propunha. A retórica seria uma habilidade prática, uma atividade empírica, uma empeiria. E, nestes termos, não poderia oferecer fundamentos sobre o assunto de que fala, por não conhecer suas causas. A distinção platônica entre dialética e retórica é reveladora: “A dialética seria, para Platão, uma arte da discussão que envolve tanto a forma quanto o conteúdo; a retórica, entretanto, seria uma arte puramente formal de persuadir sobre uma coisa qualquer, sem cuidar do valor de seu conteúdo.”(PLEBE, 1978, p. 24) Para Górgias, recordemos, o conteúdo era parte integrante da arte retórica (ela trata do justo e do injusto, do bem e do mal, do belo e do feio), o que significava que ela tinha uma forma e um conteúdo bem determinados. Para o Platão dos primeiros diálogos, a retórica é puramente formal, indiferente ao seu conteúdo, e a questão central do Górgias não poderia ser outra: qual é o tipo de persuasão produzido pela retórica e sobre que matérias ela versa?

Se para Platão forma e conteúdo não estão unidos na retórica, a finalidade de persuadir suplanta a necessidade do conhecimento do objeto em questão. Isso daria àqueles que possuíssem as técnicas de persuasão a possibilidade de apresentarem-se como sabedores de diversas matérias sendo, hipoteticamente, incompetentes em todas elas. Pistas sobre essa concepção platônica podem ser obtidas se entendermos que sua principal finalidade era a manutenção da justiça na pólis e que, na Atenas de então (assim como em nosso mundo moderno), por vezes o injusto prevalecia sobre o justo, mediante argutas técnicas de argumentação. De posse do cabedal retórico, vozes habilidosas poderiam obter vantagens significativas, mesmo que moralmente reprováveis. Nisso reside todo o descrédito enfrentado pela retórica sofística a partir de Platão, e que está, ainda que de maneira subjacente, presente na historiografia moderna.

Dois pensamentos parecem obstinadamente, entretanto, opor-se ao descrédito originado no Górgias platônico, embora apenas mais modernamente tenham sido enunciados com mais liberdade. O primeiro afirma que, se segundo o próprio Platão forma e conteúdo não estão unidos na retórica, então ela se comporta apenas como um 
instrumento de persuasão. Não pode recair sobre ela, portanto, a responsabilidade sobre os resultados que essa persuasão venha a gerar, mas sobre aquele que dela faz uso não virtuoso. O segundo pensamento é mais sutil e mais profundo, oriundo das próprias contradições platônicas, e merece uma exposição mais generosa. Chamemos à cena o talvez menos platônico dos Sócrates que possuímos:

O que vós, cidadãos atenienses, haveis sentido, com o manejo dos meus acusadores, não sei; certo é que eu, devido a eles, quase me esquecia de mim mesmo, tão persuasivamente falavam. Contudo, não disseram, eu o afirmo, nada de verdadeiro. Mas, entre as muitas mentiras que divulgaram, uma, acima de todas, eu admiro: aquela pela qual disseram que deveis ter cuidado para não serdes enganados por mim, como homem hábil no falar. Mas, então, não se envergonham disso, de que logo seriam desmentidos por mim, com fatos, quando eu me apresentasse diante de vós, de nenhum modo hábil orador? Essa me parece a sua maior imprudência, se, todavia, não denominam “hábil no falar” aquele que diz a verdade. Porque, se dizem exatamente isso, poderei confessar que sou orador, não porém à sua maneira. (...) depois, considerai o seguinte, e só prestai atenção a isso: se o que digo é justo ou não; essa, de fato, é a virtude do juiz, do orador - dizer a verdade. (PLATÃO, s.d. [a], p. 31)

A argumentação socrática é realmente penetrante. Apresenta-se ele como não hábil ao falar, quando provavelmente deveria haver consenso acerca de suas qualidades como orador. Ao fazer isso, provoca no ouvinte uma estranheza que parece mais reprová-lo do que defendê-lo, um aparente erro de cálculo. Em seguida, afirma ser a maior imprudência de seus acusadores não denominarem "hábil no falar" aquele que diz a verdade. E, neste ponto crucial, aceita-se como orador. O arremate é preciso: a verdadeira virtude do orador não reside em ser "hábil no falar", mas em que essa habilidade precisa estar a serviço da verdade; ou ainda: que apenas se constitua em verdadeira habilidade se conjugada à verdade, sendo falsa toda outra "habilidade ao falar”.

Depreendemos, por esta citação, o quanto a questão da verdade, portanto do conteúdo moral, fazia parte do julgamento da habilidade discursiva para Sócrates. Notemos ainda que a palavra retórica, embora seu sentido seja onipresente em todo o trecho e no vocabulário utilizado, não é proferida. A fina e irônica argumentação 
socrática vai ao cerne de nossa questão, ao aliar um conteúdo moral (a expressão da verdade) como distinção última de uma definição acerca da oratória que, portanto, não se sustenta por sua forma apenas, mas, primordialmente, por seu conteúdo. O próprio Sócrates, na República de Platão, cuidaria de abordar novamente a questão num nível significativamente elevado quando, em diálogo com Glauco e a propósito de orientar sua premissa, lança-nos a aparentemente despretensiosa indagação: "Mas a maneira de dizer e o próprio discurso não dependem do caráter da alma?” (PLATÃO, 1997, p. 94)

\subsection{3 - A depuração dialética}

A posição do Górgias dentre os diálogos juvenis de Platão encontra paralelo no Fedro, um dos diálogos da maturidade, ambos abordando a polêmica anti-retórica. Mas, no Fedro, tem lugar uma avaliação algo mais positiva da retórica. As críticas platônicas (via Sócrates) agora se dirigem à “retórica sofística”, tida como uma falsa retórica, e preservam a "retórica dialética”, a verdadeira retórica. E aqui nos parece adequado clarear o conceito de dialética: no platonismo, é o processo de diálogo através do qual, por meio de pontos de vista opostos, pode-se chegar a um novo patamar de consciência sobre determinado tema. Seria intrínseca à dialética, para Platão, uma busca comprometida com a verdade, que promoveria a elevação da alma das aparências sensíveis às realidades inteligíveis ou idéias. E, com efeito, a polêmica anti-retórica presente no Fedro concentra-se sobre a antítese entre a aparência e a essência, entre o parecer e o ser, e não mais entre téchne e empeiria, como no Górgias. O duplo método necessário ao discurso dialético contempla a síntese (que reúne e concentra elementos díspares ou assemelhados) e a análise (que separa e individualiza os elementos, particularizando-os). Esta retórica verdadeira, fundamentada nos preceitos da dialética, elevada ao nível dialético, sublinhemos, é ainda útil enquanto atividade social, de relação interpessoal, visto que a dialética é diálogo, arte de interrogar e responder.

Devemos acrescentar que abordagens da retórica estão também presentes em outros diálogos platônicos, como no Eutidemo, no Teeteto e no Filebo, mas sem a proeminência e a profundidade com que foram tratados no Górgias e no Fedro. Vale ressaltar ainda que, apesar da nova posição presente no Fedro, o platonismo antiretórico do Górgias marcaria profundamente toda a trajetória da retórica, imputando-lhe um preconceito moral que a acompanharia de maneira obstinada, parecendo jamais abandoná-la desde então. 


\section{3 - Isócrates e Anaxímenes}

A oposição de Platão à retórica e à sofística personificava-se em seu mais influente e talentoso adversário: Isócrates (436 - 338 a.C.). Discípulo de Górgias e de Sócrates (o que devia enfurecer Platão), procurava reunir o princípio gorgiano da persuasão à dialética socrática. Para Isócrates a palavra é dom divino, e a oratória se presta, a um só tempo, a finalidades pedagógicas e de elevação da humanidade, o que nos permite concluir que sua retórica incluía, desde sempre, a própria moralidade. Graças à influência socrática, a palavra é, para Isócrates, produtora de sabedoria, e a retórica destinada a tornar os homens sábios e bons.

A despeito disso, Isócrates parece ter se dedicado mais ao aperfeiçoamento do estilo da elocução do que ao seu conteúdo (que talvez lhe fosse naturalmente óbvio), o que lhe valeu a hostilidade de Platão e, mais tarde, a de Aristóteles.

Também pertencente ao século IV a.C. é Anaxímenes de Lâmpsaco, a quem hoje se atribui a Retorica ad Alessandrum, antes creditada a Aristóteles. É no De Institutione Oratoria, de Quintiliano, de quem falaremos mais tarde, que somos informados da classificação realizada por Anaxímenes quanto aos gêneros da retórica, que eram três: o deliberativo, o demonstrativo e o judiciário (PLEBE, 1978, p. 35-36). Esta classificação será retomada por Aristóteles e com ele terá, como veremos, uma elaboração mais minuciosa e completa, como também a terá, aliás, toda a técnica retórica.

\section{4 - Aristóteles: abrangência e organização}

Inicialmente, as posições de Aristóteles (384 - 322 a.C.) quanto à retórica foram profundamente influenciadas por Platão. Mas esta fase, transitória, logo cedeu sua vez a um pensamento próprio e original. Espírito enciclopédico, menos místico e talvez mais científico do que Platão, Aristóteles observava na retórica e na dialética algo em comum, pelo fato de não haver para ambas um assunto delimitado, preciso, sobre o qual se debruçavam. E, se o assunto poderia abarcar gêneros os mais diversos, fazia-se necessária, então, uma técnica rigorosa do argumentar, evitando que os argumentos fossem utilizados sem critério, sem método e ordem alguma. Lembremos aqui que essa já fora a preocupação de Tísias e Córax. Para Aristóteles, porém, se fazia necessária 
uma organização mais abrangente e minudente do tema, seria necessário fundar uma autêntica téchne da retórica.

\subsection{1 - A “retórica antiga” e o entimema}

Os três livros da Retórica de Aristóteles revelam, segundo Armando Plebe, duas redações diferentes, pertencentes a dois períodos diversos do pensamento retórico de seu autor. À chamada “retórica antiga” pertence o primeiro livro, enquanto o segundo e terceiro livros pertencem à “retórica recente”. Há, entretanto, uma tendência a considerar-se o segundo capítulo do primeiro livro como pertencente à retórica recente, dadas as suas características peculiares, conforme veremos.

No primeiro livro da Retórica (excetuado o segundo capítulo), Aristóteles não reservou às inflexões emotivas do discurso papel relevante. Coube preponderância às argumentações demonstrativas, chamadas provas. Sendo tarefa do orador demonstrar que algo é ou não é, aconteceu ou não, a argumentação probatória permite conclusões racionais. Mas, não sendo a retórica redutível simplesmente à lógica, sem contudo negála, o tipo de demonstração que ela deve perseguir não é o da demonstração irrefutável, que se efetua por meio dos silogismos. Recordemos que silogismos são raciocínios deduzidos a partir de premissas universalmente aceitas e que levam a conclusões logicamente estruturadas. ${ }^{1}$ Não perseguindo, porém, a demonstração irrefutável, pode a retórica concluir teses entre si contraditórias, desde que sob contextos definidos. Portanto, o método adequado à retórica é o da utilização de silogismos convincentes, mas não irrefutáveis. A estes "silogismos retóricos", Aristóteles dá o nome de entimemas.

O entimema deriva de premissas retóricas, que diferenciam-se de premissas lógicas por não oferecerem o mesmo grau de certeza. As premissas retóricas são três: as provas, as verossimilhanças e os sinais ou indícios, que possuem, respectivamente, força demonstrativa decrescente, mas se mostram, todos, suficientes para amparar um entimema. Para além da refutabilidade intrínseca do entimema há, todavia, critérios próprios de julgamento que permitem distinguir entre verdadeiros entimemas e entimemas aparentes, desde que seja empregado um méthodos.

\footnotetext{
${ }^{1}$ São exemplos de silogismos: todos os homens são mortais; Sócrates é homem, logo, Sócrates é mortal; ou ainda: se $\mathrm{a}=\mathrm{b}$ e $\mathrm{b}=\mathrm{c}$, então $\mathrm{a}=\mathrm{c}$. Etimologicamente, silogizar significa "reunir pelo pensamento".
} 
Três fatores são fundamentais a todo discurso: aquele que fala, o argumento em torno do qual se fala e a pessoa a quem se dirige o discurso. Destes três fatores, o último é, para Aristóteles, o que determina a estrutura do discurso. Assim sendo, variando o tipo de ouvinte, os discursos dividem-se em três gêneros (já delineados por Anaxímenes), que são:

- Deliberativo: que aconselha ou dissuade, baseado nas categorias do útil e do nocivo, no qual é o ouvinte um juiz de coisas futuras;

- Judiciário: que acusa ou defende, a partir das categorias do justo e do injusto, do bom e do torpe, no qual o ouvinte é juiz de coisas passadas;

- Epidíctico (ou Demonstrativo): que louva ou vitupera, mediante as categorias do belo e do feio, em que o ouvinte ajuíza acerca do talento do orador, no presente. (ARISTÓTELES, s.d., 39-41)

Cada um dos três gêneros será minuciosamente submetido por Aristóteles a uma técnica rigorosa neste primeiro livro, o que afastará a possibilidade de ser a retórica tomada como uma empeiria, como quisera Platão.

\subsection{2 - A “retórica recente” e o papel das paixões}

Se o primeiro livro da Retórica não conferia importância às inflexões emotivas no discurso, no segundo, já pertencente à “retórica recente”, pelo contrário, as paixões (páthos) são agora introduzidas como argumento indispensável da técnica retórica, bem como o elemento éthos. Não é suficiente que o discurso seja apodíctico (ou seja, baseado no que pode ser provado) e convincente, o próprio orador deve dispor-se em determinada atitude, em consonância com seus argumentos, visto que pretende persuadir e está diante de um juiz. Ao lado de uma retórica demonstrativa faz-se pertinente uma "retórica emocional”, que torna o orador digno de fé em grau mais elevado. Para Aristóteles, três são os elementos que conferem esta credibilidade emocional: a sabedoria, a virtude e a benevolência. São eles que constituem o caráter do orador, seu éthos. Este éthos é a condição para que paixões sejam devidamente despertadas nos ouvintes. A atitude e o julgamento dos ouvintes só podem ser verdadeiramente penetrados se suas paixões estiverem acesas. Pela retórica demonstrativa a persuasão não se dá por completo, pois uma mudança de juízo exige 
movimento interno, mais oportunamente realizado por uma retórica emocional (Ibidem, p.97-98).

Dois elementos, éthos e páthos, tornam-se, portanto, fundamentais. Éthos não é apenas caráter, mas também atitude, atitude moral, depreendidos quase a partir da própria presença e postura do retor. Páthos representa todo o mundo das emoções, toda a irracionalidade emocional, mais do que apenas uma inflamada emoção, mais do que o sentido usual de “paixão”:

Os Gregos sempre sentiram a experiência das paixões como um fato misterioso e terrível no qual experimentamos uma força que antes está em nós e nos possui, do que é possuída por nós. A própria palavra, pathos o comprova: como o seu equivalente latino passio, indica alguma coisa que acontece aos homens, vítimas passivas. (DODDS apud PLEBE, 1978, p. 43)

Ao incluir em sua Retórica as paixões, Aristóteles integrou as antigas correntes pitagóricas e sofísticas. Ao organizar e clarificar o papel das paixões no discurso, fez as pazes com as escolas que defendiam a importância da psicagogia na oratória. Se o Aristóteles juvenil fora contrário ao emprego das paixões, então associadas às doenças e loucuras, o Aristóteles maduro do segundo livro da Retórica entende que, usadas de maneira conveniente, as paixões são proveitosos instrumentos em favor da virtude. E mais, se as paixões participam da téchne rhetoriké, poética e retórica passam a ter laços mais profundos:

(...) assim como no âmbito das paixões cantadas pela poesia a catarse poética realiza uma função esclarecedora, projetando sobre coisas acontecidas a luz da possibilidade universal, assim também, no âmbito da demonstração retórica, ilumina de modo não diferente as paixões humanas à luz do silogismo retórico ou entimema. (PLEBE, 1978, p. 44-45) 


\subsection{3 - Os tópoi ou "lugares" retóricos}

Com o acréscimo das paixões, mesmo a retórica demonstrativa passa por transformações. O raciocínio retórico aristotélico, primordialmente dedutivo no primeiro livro, passa a ser também indutivo no segundo. A indução retórica possui uma dupla função: ou contrapõe-se ao entimema ou é parte integrante dele. Quando o entimema é fruto de uma dedução retórica, a indução se lhe opõe, mas se uma indução possibilita um exemplo, então este pode ser constitutivo de um entimema. O próprio Aristóteles reformula, então: às três premissas retóricas já classificadas (as provas, as verossimilhanças e os sinais ou indícios) uma quarta vem se juntar, o exemplo. De cada uma dessas quatro premissas deriva um entimema específico: da prova, o entimema apodíctico; do exemplo, o entimema indutivo; do verossímil, o entimema anapodíctico (sem caráter de necessidade); do sinal, o entimema assilogístico ou aparente.

Complementando as premissas, estão os “lugares” retóricos ou tópoi, os meios de argumentação adequados a cada gênero (deliberativo, judiciário e epidíctico). Sobre a teoria dos tópoi, há muito discutida, ainda pesam importantes contradições. Os "lugares” retóricos ou tópoi dividem-se em comuns e próprios, e sua definição aparece no capítulo II do primeiro livro. Este fato garante a esse capítulo especial atenção dos estudiosos, visto parecer adequar-se mais à “retórica recente” e, paradoxalmente, encontrar-se alocado no primeiro livro. Deixemos que o próprio Aristóteles nos fale:

Digo que são silogismos dialéticos e retóricos aqueles a propósito dos quais falamos de lugares. Os lugares comuns são os que versam sobre a justiça, a física, a política e sobre muitos assuntos que diferem por espécie, tal como o lugar do mais e do menos. De fato, dele será possível formar silogismo ou formular um entimema, indiferentemente, tanto a respeito da justiça quanto a respeito da física ou a respeito de qualquer assunto; contudo estes argumentos diferem por espécie. Próprios são, porém, os lugares que provêm das premissas relativas a cada espécie e a cada gênero; por exemplo, há premissas sobre questões de física das quais não se pode derivar nem entimema, nem silogismo sobre questões de ética; e, a respeito desta, há outras das quais não se podem derivar [entimema e silogismo] a respeito da física. (ARISTÓTELES apud PLEBE, 1978, p. 47-48) 
Os lugares comuns, menos freqüentes na retórica, dizem respeito a causas de caráter geral mas, no que diz respeito a estas, têm autêntico valor dialético. Os lugares próprios, mais numerosos na retórica são, entretanto, mais imprecisos quanto às ciências particulares de que tratam. Lugares comuns são termos de comparação geral, que podem ser aplicados a variados assuntos, pois produzem considerações quanto a hierarquias. São menos numerosos justamente por serem aqueles que pretendem abarcar variados gêneros, sendo, então, menos específicos. Já os lugares próprios são aqueles que se referem às especificidades de cada gênero, sendo, portanto, mais numerosos e específicos, mas geram entimemas de caráter menos abrangente.

Isso torna os lugares comuns superiores aos próprios, pois enquanto os primeiros constituem a parte autenticamente dialética da retórica os últimos são apenas expressão de conhecimentos particulares imperfeitos. Essa última observação vai ao encontro de posições platônicas expressas no Fedro (nas quais a dialética tinha uma função depuradora sobre a retórica), integrando-as ao conjunto do pensamento aristotélico sobre retórica. Mais à frente, Aristóteles subdivide os lugares comuns em dois grupos: o dos entimemas reais e o dos aparentes. Todavia, interpretações contraditórias tentam estabelecer quais as relações entre os lugares comuns e as premissas, ponto obscuro ainda nos dias de hoje para muitos estudiosos.

\subsection{4 - O estilo e as divisões do discurso}

O estilo retórico foi abordado por Aristóteles no terceiro livro da Retórica. Três são os elementos fundamentais do estilo: a metáfora, as antíteses e o vigor, sendo os dois primeiros os mais importantes. Sustentando que o estilo teria se originado sob forma poética, num dado momento teria, contudo, a prosa apartado-se da poesia. Persistiu na retórica (afeita à prosa), entretanto, o elemento que a unira primordialmente à poesia: as metáforas. Estas, graças a sua força expressiva, à qualidade imagética ou mesmo enigmática que possuem, causam imediato interesse, reivindicando a atenção do ouvinte, e terminam por conferir clareza ao estilo. Faz-se necessário, porém, dominar a habilidade de encontrar a metáfora apropriada, habilidade comum ao poeta e ao retor. As metáforas devem ser criadas em conexão com os elementos principais do termo original, mas nunca de um modo evidente e previsível e devem, ainda, ser construídas segundo suas qualidades sonoras. Quanto à antítese, desde sempre apreciada pelos retores como instrumento privilegiado para as refutações, funda-se nos pares de opostos 
que, apresentados, permitem criteriosa comparação e são perfeitos instrumentos persuasivos. Assim como o era para a tradição pitagórica e sofística, também no aristotelismo a antítese é elemento essencial da expressão retórica.

Ainda no terceiro livro, nos capítulos XIII a XIX (o último), Aristóteles organiza as partes do discurso, retomando as divisões então tradicionais e justificando a necessidade ou não de tais estruturas segundo o gênero do discurso abordado. Em seguida, passa a esmiuçar essas partes, conforme estudaremos agora.

Em todo discurso devemos ter no mínimo duas partes: na primeira o assunto é apresentado, na segunda temos a demonstração. À primeira chamamos exposição, à segunda provas. Uma narração deveria apenas ter lugar no gênero judiciário. Já o prólogo, a discussão contraditória e a recapitulação seriam afins apenas ao gênero deliberativo. O epílogo ou peroração não se faria necessário se o desenvolvimento não se mostrasse demasiado longo, do contrário sim; o exórdio prepara e dispõe os ouvintes para o que se segue, sendo bastante útil. Assim, os termos admitidos indistintamente a todos os discursos, seriam, no máximo, quatro: o exórdio, a exposição, a prova e o epílogo. A refutação e a controvérsia fariam parte das provas, estando nelas contidas. A narração, se necessária, estaria contida na exposição. ${ }^{2}$

O exórdio inicia o discurso, correspondendo ao prólogo na poesia e ao prelúdio na aulética (arte de tocar “aulo”, ou flauta). E a comparação utilizada por Aristóteles não nos poderia parecer mais oportuna:

O prelúdio é semelhante ao exórdio no gênero epidíctico; com efeito, os tocadores de flauta, quando conhecem alguma ária, ensaiam-na preludiando no início da música que dá o tom. Eis qual deve ser a composição nos discursos demonstrativos; começa-se por exprimir logo de entrada o que se pretende dizer e apresenta-se o plano. Todos os oradores conformaram-se com esta regra. (ARISTÓTELES, s.d., p. 206)

A exposição deve ser clara e precisa, abordando o assunto em questão de maneira inequívoca, a fim de transportar o ouvinte ao centro do tema. Nas provas temos, por definição, o momento privilegiado para os entimemas virem à tona. No

\footnotetext{
${ }^{2}$ Uma exposição mais minuciosa de todas essas partes será apresentada logo a seguir.
} 
epílogo ou peroração têm lugar a recapitulação (concisa, de preferência) e ainda a expressão última do páthos adequado ao tema.

Em cada uma dessas partes deve-se evitar a prolixidade ou a concisão exagerada, mas manter-se eqüidistante destes extremos. O meio termo é dado pela correta explanação, na qual tudo o que se faz pertinente possui o tempo necessário para ser comunicado sem, entretanto, entediar ou desinteressar o ouvinte, ou ainda prejudicar a sua efetiva memorização.

A retórica aristotélica teve, como não poderia deixar de ser, grande êxito, e influenciou todos os escritos posteriores sobre o tema. Dada a complexidade e abrangência da organização proposta por Aristóteles, pouco restou aos que imediatamente lhe seguiram senão aprofundar-se em alguns pontos nos quais o mestre supostamente teria sido sucinto demais (é o que fizeram Demétrio de Falera e Teofrasto). Obviamente, determinadas correntes alternaram-se, valorizando ora um ora outro aspecto já postos em confronto anteriormente e acomodados pelo arcabouço aristotélico. Entretanto, tão logo um novo patamar qualitativo é alcançado, novas luzes se lançam a iluminar novos desafios. E, quanto mais abrangente tenha sido a abordagem de Aristóteles, mais sementes e fendas propiciou aos que se lhe seguiram, embora lhes tenha exigido uma bagagem conceitual significativamente mais elaborada.

\section{5 - Estóicos: Zenão e Hermágoras}

Apesar das observações em contrário que nos chegam de Cícero (de quem trataremos mais à frente), é importante a contribuição dada pelos estóicos à retórica. $\mathrm{O}$ estoicismo apresenta-se como doutrina fundamentada na rigidez e firmeza de princípios, bem como numa resignada aceitação do destino. Aos estóicos é atribuída a valorização da retórica em virtude de sua criatividade estilística. As estruturas poéticas e musicais são, para os estóicos, superiores até à prosa filosófica no que tange à propriedade de expressar a grandeza divina; os metros, as melodias e os ritmos são veículos privilegiados que conduzem à verdadeira contemplação das coisas celestes. Se anteriormente a Aristóteles (e ainda um pouco com ele) a retórica carrega o caráter de persuasão capaz de criar uma crença, enquanto caberia à filosofia prover ensinamentos, para Zenão de Cício (335 - 264 a.C.) a diferença essencial entre dialética e retórica não se dá no caráter não científico atribuído a esta última, mas no grau de concisão obtido. 
Tanto retórica quanto dialética buscam o objetivo do "falar bem”, mas este objetivo traz, como condição intrínseca, o compromisso com a verdade (PLEBE, 1978, p. 5758). E nisto a concepção de Zenão é frontalmente oposta ao platonismo do Górgias, ressaltemos, embora a preocupação moral também fosse inerente ao estoicismo. Ao alçar a retórica a este degrau mais nobre, já visitado por Sócrates, Zenão renovou o debate platônico entre retórica e dialética, entre retórica e filosofia. O que Aristóteles houvera julgado superar em sua incomparável e criteriosa exposição voltava à tona.

Após Zenão, três outros estóicos dos séculos III e II a.C. destacaram-se entre os retores: Cleanto, que considerava a retórica uma das seis partes de que se compunha a filosofia (a saber: dialética, retórica, ética, política, física e teologia); Crisipo, que, assim como Aristóteles, propôs divisões e funções específicas para cada parte do discurso (invenção, elocução, disposição, recitação - às quais, às vezes, os estóicos acrescentavam a nóesis, ou estudo do argumento da causa), divisões que se tornarão constitutivas de toda a técnica retórica; e Diógenes de Babilônia (século II a.C.), que julgava, em consonância com Zenão, ser a retórica uma ciência da verdade, não menos do que a lógica, pois nada seria mais persuasivo do que a própria verdade (Ibidem, p. 59-60).

A retórica de Hermágoras de Temno (século II a.C.) é tida como fundamental na retórica antiga, mesmo aceitando-se que a profundidade alcançada por Aristóteles jamais tenha sido igualada. Embora tenha Hermágoras provindo do estoicismo, sua doutrina abriga orientações filosóficas oriundas de várias tendências. Ele avaliava os preceitos retóricos por suas implicações e conteúdos mais abrangentes, e este ecletismo renovou e deu novo impulso aos estudos retóricos, especialmente livrando-os da rigidez com que deviam adequar-se a formalismos acadêmicos. Abrigando em seu sistema tendências diversas, Hermágoras tem seu nome ligado principalmente à introdução da teoria das teses. Conforme esta teoria, a retórica não se ocupa necessariamente apenas de hipóteses (controvérsias particulares e individuais em que são definidas as pessoas da controvérsia), mas também das teses (questões universais, sem determinação de pessoa alguma como objeto da controvérsia) (Ibidem, p. 61). A partir da introdução das teses no âmbito da retórica, reacendeu-se o debate entre retórica e filosofia, com os retores reivindicando para si o direito de tratar de questões gerais, tidas como território exclusivo dos filósofos. Embora Teofrasto e alguns estóicos já tivessem discutido teses gerais com os meios da retórica, coube a Hermágoras o mérito de ter dado às teses a primeira teorização explícita. Não há como negar, entretanto, que a diferenciação entre 
teses e hipóteses está fundamentada na distinção aristotélica entre lugares comuns e próprios (Ibidem, p. 62). Assim sendo, a doutrina de Hermágoras pode ser vista como um desenvolvimento inovador que se vem juntar ao escopo do aristotelismo, complementando-o. Após Hermágoras, a retórica grega perderá sua preponderância no mundo antigo, direito que passará, paulatinamente, à retórica latina.

\section{6 - Retórica latina}

\subsection{1 - A Rhetorica ad Herennium}

A Rhetorica ad Herennium é o mais antigo tratado retórico latino de que dispomos. Embora nos tenha chegado o texto integral, este se apresentava anônimo, e foi erroneamente atribuído a Cícero, sendo hoje, quase unanimemente, atribuído a Cornifício (século I a.C.), de quem falará, mais tarde, Quintiliano. Devendo suas fontes principais a Aristóteles e Hermágoras, o autor desloca, entretanto, o foco de seu interesse da disputa filosófica para preceitos e classificações da matéria. Ao fazê-lo, instituiu, com base nas fontes gregas, toda a terminologia retórica latina, adotada praticamente inalterada a partir de então. Os três gêneros aristotélicos são retomados (judiciário, demonstrativo e deliberativo) e, em seguida, a técnica retórica é subdividida segundo fizera Crisipo (invenção, elocução, disposição, recitação), com um acréscimo, a memória, ao invés da nóesis proposta pelos estóicos. Assim, a divisão da matéria retórica, já em sua terminologia latina, compreende cinco partes: a inventio, a dispositio, a elocutio, a memoria e a pronunciatio. Já a subdivisão do discurso (na dispositio) se dá em seis partes: o exordium, a narratio, a propositio (ou divisio), a confutatio (ou refutatio), a confirmatio e a conclusio (ou peroratio). (Ibidem, p. 65-66). Fixemos estas subdivisões, pois terão importantes desdobramentos em nossas conclusões futuras.

\subsection{2 - Cícero}

Primeira obra juvenil de Cícero (106 - 43 a.C.) dedicada à retórica, o De Inventione possui notável semelhança com a Rhetorica ad Herennium, mas o Cícero maduro em De Oratore, Orator e Brutus, ou ainda no De Optimo Genere Oratorum, nas Partitiones oratoriae e nos Topica, volta à polêmica entre retórica e filosofia, tema 
recorrente, enfrentado por todo grande pensador que se tenha dedicado à retórica. Para Cícero, considerado o maior dos prosadores romanos e admirado por seus escritos políticos, filosóficos e retóricos, ambas, filosofia e retórica, são disciplinas complementares entre si. Não é possível ser verdadeiro orador sem o alicerce filosófico que permite distinguir os gêneros e as espécies relativos a cada assunto, julgar o verdadeiro e o falso, notar sutilezas sobre contradições e ambigüidades. Por outra via, àquele que é filósofo e deseja ser orador não pode faltar a técnica oratória, que lhe permite expressar de maneira conveniente suas convicções.

A fim de evitar um formalismo puro, carente de conteúdo, Cícero propõe que se acrescente, ao estudo da retórica, o aprofundamento dos assuntos tratados, sem que se descuide, porém, da técnica utilizada para exprimi-los:

De fato, a abundância dos assuntos gera a abundância das palavras; e se existe nobreza nos próprios assuntos de que se fala, surge da natureza do assunto um certo esplendor natural das palavras (...) Assim, facilmente, na abundância dos assuntos, da própria natureza fluirão os ornamentos da oração, sem guia algum, desde que seja ela exercitada. (CÍCERO apud PLEBE, 1978, p. 68)

Têm as palavras, para Cícero, o poder de brotar dos lábios daquele que realmente conhece o assunto que expõe. E brilhantes palavras não nascem de pensamentos tenuamente concebidos, assim como retos pensamentos não se elevam senão à luz das palavras.

Considerados esses preceitos, Cícero reivindica à retórica o status de ars, retomando a controvérsia entre Platão e os sofistas. Na "confluência do elemento racional da técnica abstrata com o elemento empírico da experiência e do exercício” está a ars, então claramente aplicável à disciplina retórica (PLEBE, 1978, p. 70). Com efeito, a valorização da retórica na Antigüidade teve seu ápice com Cícero, após o que viu-se em franca decadência, especialmente após a perda da liberdade oriunda das mudanças políticas em Roma, com a queda da república (o que esvaziou os espaços de discussão e debate, suprimindo a participação dos cidadãos e desestimulou a circulação de idéias, restringindo a liberdade em expressá-las). Ainda teríamos tempo, entretanto, de conhecer as idéias de Tácito e Quintiliano. 


\subsection{3 - Tácito e Quintiliano}

Tácito (c.55 - 120 d.C.), em seu Dialogus de Oratoribus, classificou oratória e poesia ambas como eloquentia (o que nos remete à retórica gorgiana) e as diferenciou pelas seguintes características: a utilitas (aqui como “utilidade social”) é própria da oratória e não da poesia, a voluptas (pertinente à sensibilidade algo exacerbada) pertence apenas à poesia. O caráter social é pertinente à oratória, mas não à poesia, que habita um mundo fantástico próprio.

Último grande retor latino, Quintiliano (c.35 - 100 d.C.) escreveu a sua Institutio Oratoria apoiado nos gregos e latinos que o precederam, especialmente em Cícero. Registrou o parentesco e as diferenças entre poética e retórica à maneira aristotélica, e enfrentou a polêmica entre retórica e filosofia assumindo posição consoante à de Cícero. Na Institutio Oratoria dividiu o discurso em partes e as caracterizou, como fizera Aristóteles. Suas posições não são necessariamente inovadoras, mas sua exposição é considerada extremamente clara e sua doutrina perfeitamente organizada (embora sem a beleza do estilo ciceroniano), possuindo o mérito de ter renovado e dado continuidade à tradição grega e latina acerca da retórica. E já o ocaso da retórica latina avançava.

\section{7 - Crepúsculo da retórica antiga}

Embora tivesse o foco da retórica antiga se deslocado dos gregos para os latinos nos dois primeiros séculos da era cristã, podemos destacar algo neste apagar das luzes da retórica ainda entre os gregos. Desenvolvendo-se nos moldes da retórica aristotélica e nas teorias de Hermágoras, temos uma divisão geral dos retores em duas correntes principais, a saber: aquela que privilegia o discurso racional e nega papel fundamental às paixões em contraposição àquela que afirma ser a psicagogia elemento primordial para que a persuasão se dê.

Quatro retores gregos destacam-se nesta época: Cecílio de Calacte, que desenvolveu um preceituário mais esquemático e de classificação; Dionísio de Halicarnasso, que tratou da disposição e harmonia das palavras, valorizou a metáfora e defendeu o retorno à pureza da língua grega clássica ou "aticismo"; Apolodoro de Pérgamo, que privilegiava os aspectos racionalistas da doutrina aristotélica e negava a importância da psicagogia; e Teodoro de Gadara, mais jovem que os demais, o qual 
preconizava que apenas o entusiasmo e a paixão poderiam levar à persuasão. Em torno da controvérsia entre conceder ou não às paixões importante papel na teoria retórica surge o tratado anônimo Do Sublime, considerado a última obra-prima da retórica grega. Dionísio de Halicarnasso e Cássio Longino (este último, retor do III século d.C.) foram já apontados como os prováveis autores, embora hoje a hipótese mais aceita seja a de que um discípulo de Teodoro de Gadara, chamado Hermágoras (homônimo de Hermágoras de Temno), seja o autor verdadeiro. Tomaremos a liberdade de chamá-lo simplesmente Anônimo.

O Anônimo opõe-se ao utilitarismo de fundo moral proposto por Aristóteles e pelos estóicos à retórica, segundo o qual esta presta-se, em primeiro lugar, à harmonia social. Preconiza o Anônimo que o excepcional, o extraordinário, é que gera a verdadeira persuasão. Junto ao ímpeto da paixão está também a imaginação, que é a criadora do pensamento gerador de palavras. Mas ambas, paixão e imaginação, são resultado de uma genialidade inata, caracterizada por um grandeza da alma. Entretanto, o Anônimo não conferia exclusivamente ao páthos toda a tarefa de uma teoria retórica, o que caracterizaria uma retórica do irracional, conforme já vimos. Optou por agregar às duas características primeiras, paixão e imaginação, outras três mais afeitas à téchne: a utilização particular de figuras do pensamento e do estilo (por ele denominada schémata); a nobreza de expressão, que compreende a correta escolha da palavra; e a composição, união virtuosa de todos os elementos no discurso (que ele denominou syntesis). Dessas cinco fontes é que derivaria o Sublime, para o Anônimo (Ibidem, p. 75-77).

Entre os séculos II e IV d.C. floresceu na Grécia a chamada Segunda Sofística (a "primeira" remonta ao século V a.C.) que, embora não tendo acrescentado conteúdo significativo ao escopo retórico, o manteve atualizado segundo a sociedade de sua época. E, assim como Quintiliano representa o último apogeu e já o início da decadência latina, também a Segunda Sofística representa o derradeiro sopro da retórica grega. A respeito deste momento ímpar, divisor de águas também para a disciplina retórica, assim se manifestou Armando Plebe:

O ocaso da retórica antiga não significou, contudo, a sua morte. Aliás, na Idade Média, a retórica ocupará um lugar inconfundível e inapagável, na qualidade de uma das três disciplinas do trivium, ao lado da gramática e da lógica, e das quatro disciplinas do quadrivium, (aritmética, música, geometria e astronomia). 
Entretanto, jamais voltará um momento histórico em que a retórica venha a ocupar um posto tão elevado quanto no pensamento ciceroniano, em que constituía, ao lado da filosofia, o supremo grau da educação e do saber humano. (Ibidem, p. 81) 


\title{
Capítulo 2 - Formas Musicais
}

De maneira geral, as definições comumente encontradas nos principais tratados sobre formas musicais afirmam que a Forma em música é o modo pelo qual as idéias musicais são organizadas numa composição, de maneira a constituírem um todo coerente.

\section{1 - Considerações gerais}

Zamacois afirma que uma composição musical não é mais do que um conjunto organizado de idéias musicais, e que essa organização constitui sua forma, sua estrutura, sua arquitetura (ZAMACOIS, 1979, p. 3). Hugo Riemann nos faz notar que o termo formas musicais é claramente derivado do universo das artes plásticas, nas quais há a realidade visual e táctil de uma forma, enquanto na música, cuja dimensão privilegiada é o tempo, é a memória que apreende a forma (RIEMANN, 1943, p. 17). Para Schoenberg, os elementos devem funcionar de maneira orgânica, e a coerência e a lógica concorrem para que a compreensibilidade seja possível:

\begin{abstract}
Sem organização, a música seria uma massa amorfa, tão ininteligível quanto um ensaio sem pontuação, ou tão desconexa quanto um diálogo que saltasse despropositadamente de um argumento a outro. Os requisitos essenciais para a criação de uma forma compreensível são a lógica e a coerência: a apresentação, o desenvolvimento e a interconexão das idéias devem estar baseados nas relações internas, e as idéias devem ser diferenciadas de acordo com sua importância e função. (SCHOENBERG, 1991, p. 27)
\end{abstract}

Sendo a música uma arte que se dá no tempo, sua forma somente pode ser apreendida na medida em que a memória puder reter e relacionar os materiais musicais enunciados. Portanto, em toda composição musical está em jogo um delicado equilíbrio entre repetição e contraste. A ausência de repetição não permite à memória fixar as idéias centrais, mas o excesso de repetições pode levar ao desinteresse. A presença de contrastes dá vivacidade e interesse à composição, mas seu excesso acarreta incoerência e desorganização, impedindo a memória de apreender a estrutura total. É de suma 
importância, pois, que o discurso alterne repetição e contraste, de modo a se obter o desejado equilíbrio formal.

A carência de idéias musicais por certo reduz a potencialidade de uma boa organização formal, mas, por outro lado, o excesso de idéias pode acarretar uma estrutura confusa. E se as idéias musicais não bastam por si, mas precisam ser adequadamente tratadas, isso é função da Forma. Faz-se necessária, portanto, uma delimitação entre idéias principais e secundárias que as hierarquize. A esse respeito, assim se expressou Zamacois:

Não é suficiente a inspiração das idéias musicais; é necessária também a inspiração na maneira de tratá-las. Se o primeiro inimigo do compositor é a carência de idéias, o segundo é a superabundância das mesmas. (...) Há que se saber eleger as idéias, centrar a atenção nas necessárias e descartar as desnecessárias, as quais, sem dúvida, podem ser excelentes para outra oportunidade. ${ }^{3}$ (ZAMACOIS, 1979, p. 3) [tradução nossa] ${ }^{4}$

Essa organização das idéias musicais pressupõe divisões e subdivisões que geram seções ou partes diferentes, e ainda hierarquias quanto à importância de determinados materiais em relação a outros. A nomenclatura dessas divisões e subdivisões, suas funções e características principais e a maneira como se fazem adequadas aos diferentes tipos formais compõem o conteúdo do estudo das Formas musicais, como veremos mais à frente. A terminologia formal é abundante, sendo por vezes imprecisa: temos diferentes acepções para denominações iguais e vice-versa. Algumas vezes a nomenclatura não se refere ao plano estrutural da obra, como seria de se supor.

Alguns tipos formais tiveram tamanho uso histórico que transformaram-se em protótipos, mas é a evolução e a renovação dos tipos formais que garante-lhes a sobrevivência. Vários tipos formais tiveram importância em períodos determinados,

\footnotetext{
${ }^{3}$ No original: "No es suficiente la inspiración de las ideas musicales; es necesaria también la inspiración en la manera de tratarlas. Si el primer enemigo del compositor es la carencia de ideas, el segundo es la superabundancia de las mismas. (...) Hay que saber elegir las ideas, centrar la atención en las necesarias y desechar las innecesarias, las cuales, sin embargo, pueden ser excelentes para otra oportunidad."

${ }^{4}$ Deste ponto em diante, todas as notas de rodapé que trouxerem o texto em outra língua referem-se a traduções nossas, salvo se especificadas em contrário.
} 
sendo substituídos ou transformados em outros, ou ainda caindo em desuso. Mesmo os tipos formais mais significativos não puderam manter-se inalterados, mas foram freqüentemente renovados.

Zamacois (p. 4,5) nos relembra de que é na época compreendida entre Bach e Beethoven que podemos notar o florescimento dos grandes tipos formais, e que é no gênero da música pura (aquela que não pretende expressar algo extramusical) que o aperfeiçoamento formal melhor revelou-se. Na época imediatamente anterior (Renascença, era de ouro da polifonia vocal) o cantus firmus e o texto musicado (religioso ou profano) constituíram-se nos princípios construtivos. A Idade Média e épocas mais remotas não têm grande significação para o estudo das formas. O Romantismo enriqueceu o conteúdo, mas raramente o protótipo formal em si. A música do século XX trabalhou sobre variações dos protótipos, ou procurou o aformalismo, ou ainda pregou a idéia de que cada composição havia de engendrar sua própria (e inédita) forma (ZAMACOIS, 1979, p. 4-5). Portanto, os instrumentos aqui apresentados dirão respeito, principal mas não exclusivamente, à tradição tonal.

\section{2 - Os elementos formais}

Visto ser a Forma a organização dos materiais musicais num todo coerente, a priori todos os elementos utilizados numa composição têm relevância formal: indicações de andamento e caráter, instrumentação e orquestração, variações timbrísticas e de dinâmica. Mas para a análise do repertório tradicional e por razões históricas, o ritmo, a melodia e a harmonia têm preponderância como elementos constitutivos dos tipos formais. As sucessões melódico-rítmico-harmônicas vão constituindo fórmulas e grupos de diferentes extensões, cujas denominações não obedecem a um padrão único que houvesse sido acordado pelos tratadistas. Apesar disso, cumpre-nos arriscar algumas definições, com vistas a uma nomenclatura mínima a ser adotada no presente estudo.

\subsection{1 - Tema}

Fragmento musical de sentido completo e personalidade relevante, o tema é normalmente delimitado por uma cadência. Embora alguns identifiquem motivo com tema, para a maioria dos tratadistas o motivo é o arranque inicial do tema, seu elemento 
gerador, estando, portanto, contido no tema. É característica do tema ser posteriormente utilizado em variações, modificações, desenvolvimentos. Por vezes, a definição de tema passa até pela satisfação desta condição. Conforme veremos, o tema pode coincidir, estruturalmente, com a frase ou com o período, mas raramente com a semifrase.

\subsection{2 - Desenho}

Conforme Zamacois, desenho é um discurso melódico de ritmo preponderantemente uniforme e carente de precisão temática, sendo o padrão rítmicomelódico insistentemente repetido (ZAMACOIS, 1979, p. 8). Na maioria das vezes toma o aspecto de uma sucessão de arpejos. Vezes há em que se constitui no discurso musical propriamente dito, em outras ocasiões é utilizado como padrão de acompanhamento para um tema.

\subsection{3 - Motivo}

Hugo Riemann define motivo como a célula primeira do tecido musical, elemento de mínima extensão que possui sentido completo e uma existência autônoma (RIEMANN, 1943, p. 20).

Podemos afirmar, numa abordagem acentuadamente agógica, que ársis e thésis são a causa inicial de todo movimento musical, e que esse impulso, primordialmente rítmico, quando conectado às alturas, dá origem ao motivo.

Ársis é o impulso inicial, ritmicamente representado pela anacruse (levare), correspondendo à inspiração no processo respiratório, à tensão no âmbito físico e psicológico, à sístole cardíaca. Thésis é repouso, apoio rítmico sobre tempo forte do compasso (battere), correspondendo à expiração na respiração, ao relaxamento físico e psicológico, à diástole cardíaca. Do ponto de vista harmônico, ársis coincide com a função dominante, enquanto thésis é qualificada pela tônica.

Para Giulio Bas, há duas posições métricas possíveis para que o motivo se construa. A primeira, sua concepção original, é a que satisfaz a tendência espontânea do movimento, ou seja, levare e battere, tensão e repouso; são os motivos que iniciam sobre a anacruse. Os motivos que invertem essa ordem, os téticos, são já uma variação da posição original, metricamente qualificada: “Esta dupla posição corresponde, no que 
diz respeito ao ritmo, à liberdade de que se dispõe, no que tange ao juízo e à vontade, de aceitar ou de refutar.” ${ }^{5}$ (BAS, 1964, p. 17)

O primeiro caso é o que afirma e decide, enquanto o segundo refuta. O primeiro repousa, o segundo promove um final em suspensão.

O motivo é a célula musical originada deste impulso inicial e de seu conseqüente repouso, da ársis e thésis, desta respiração primordial, portanto cíclica, ilimitada e infinita, pneuma ápeiron, para os gregos. Os pares de opostos que participam da elaboração de nossos conceitos (tais como som e silêncio, luz e escuridão) estão presentes já na célula geradora de todo o movimento musical. Isso manifesta o caráter orgânico do motivo e o coloca simbolicamente afim a toda manifestação universal.

Não nos parece supérfluo sublinhar que motivo deriva, etimologicamente, da mesma raiz da qual também derivam movimento e emoção, esta última originalmente sob a acepção de movimento interno que leva à ação. ${ }^{6}$

O fato de o motivo possuir um perfil rítmico-melódico notável nos leva a relembrar as relações intrínsecas (que teimam em permanecer ocultas, conquanto sejam óbvias) entre duas das propriedades do som (duração e altura), assim enunciadas por Wisnik:

Assim como o corpo admite ritmos somáticos (a exemplo do sanguíneo) e ritmos psíquicos (como as ondas cerebrais), que operam em diferentes faixas de onda, as freqüências sonoras se apresentam basicamente em duas grandes dimensões: as durações e as alturas. (...) Mas se as freqüências rítmicas forem tocadas por um instrumento capaz de acelerá-las muito, a partir de cerca de dez ciclos por segundo, elas vão mudando de caráter e passam a um estado de granulação veloz, que salta de repente para um outro patamar, o da altura melódica. A partir de um certo limiar de freqüência (em torno de quinze ciclos por segundo, mas estabilizando-se só em cem e disparando em direção ao agudo até a faixa audível de cerca de quinze mil hertz), o ritmo “vira” melodia. (WISNIK, 1989, p.18)

Schoenberg nos ensina que o motivo é gerador de unidade e coerência, contribuindo para a fluência e compreensibilidade do discurso; que ele é como o

\footnotetext{
5 "Questa doppia posizione corrisponde, in fatto di ritmo, alla libertà di cui si dispone, in fatto di giudizio e di volontá, d'accettare o di rifiutare.”

${ }^{6}$ Do latim, motus, motivus, movere, emovere. (HOUAISS, 2001, p. 1968)
} 
“germe” que dá origem a toda uma composição e que, ao ser variado, é a manutenção de seu aspecto rítmico que lhe garante imediato reconhecimento, a despeito de suas características melódicas e harmônicas (SCHOENBERG, 1991, p. 35-36). Todos os importantes tratados sobre formas musicais consideram o motivo como portador de uma relação rítmico-melódica de características marcantes, associada a uma harmonia intrínseca (que pode ou não ser enunciada ou confirmada), e que se presta a ulteriores desenvolvimentos e modificações.

\subsection{4 - Frase e Período}

Os motivos, repetindo-se, articulando-se a outros ou desenvolvendo-se, formam unidades maiores que, por sua vez, ao unirem-se, abarcam seções ainda mais extensas, até o momento em que determinam conteúdos musicais que parecem abarcar o ciclo completo de uma idéia musical. A nomenclatura dada a essas divisões ou seções do discurso musical varia de autor a autor, embora a lógica que permeie essas divisões seja uniforme. Sempre da maior seção para a menor, vejamos a nomenclatura utilizada pelos principais tratadistas:

- período, frase, semifrase, motivo ou inciso (Giulio Bas)

- frase, período, subperíodo, (membros de subperíodo), motivo (Zamacois)

- período, semiperíodo, grupo, motivo (Riemann)

- período ou sentença, frase, motivo (Schoenberg)

Apesar das diferentes denominações, os conteúdos correspondem-se nas estruturas citadas. Entretanto, devemos ressaltar que, para Schoenberg, período e sentença não são exatamente sinônimos, embora sejam assemelhados. A distinção que entre eles se estabelece é devida ao contorno da segunda frase e mesmo à sua continuação. Se a segunda frase é repetição quase literal da primeira, apenas acomodando-se a uma nova pontuação em seu final, estamos diante de uma sentença. Já a construção do período é por ele assim caracterizada:

O período difere da sentença pelo fato de adiar a repetição. A primeira frase não é repetida imediatamente, mas unida a formas-motivo mais remotas (contrastantes), 
perfazendo, assim, a primeira metade do período: o antecedente. Após este elemento de contraste, a repetição não pode ser muito adiada, a fim de não colocar em perigo a compreensibilidade; daí o fato de a segunda metade, o conseqüente, ser construída como uma espécie de repetição do antecedente. (SCHOENBERG, 1991, p. 51)

Por “formas-motivo mais remotas” podemos depreender variações do motivo inicial, utilizadas para revelar suas particularidades não de todo perceptíveis. Ainda com Schoenberg, podemos caracterizar a Frase como uma unidade estrutural "aproximada àquilo que se pode cantar em um só fôlego.” (SCHOENBERG, 1991, p. 29)

Em nosso presente estudo adotaremos (e já utilizaremos a partir deste ponto) a seguinte terminologia, da maior estrutura para a menor: período, frase, semifrase, motivo. Se necessário, utilizaremos "membros de semifrase" entre a semifrase e o motivo e, apenas quando julgarmos realmente pertinente, faremos menção à distinção entre período e sentença posta em relevo por Schoenberg.

\subsection{5 - Ictus}

Apenas com Zamacois temos a definição de Ictus, que nos parece de extrema importância, mas que não é informada pelos outros tratadistas consultados e que, freqüentemente, é ignorada nos estudo formais.

Segundo Zamacois, "todo período, frase e semifrase têm, como suportes extremos, dois tempos fortes, o primeiro e o último daqueles que abarcam, e que recebem, respectivamente, o nome de 'ictus' inicial e 'ictus' final.” ${ }^{7}$ (ZAMACOIS, 1979, p. 11) ${ }^{8}$ Para determinar a posição dos ictus deve-se diferenciar, por vezes, o compasso escrito do “compasso real”, quando não coincidem (exemplos seriam as muitas valsas, escritas em compasso ternário, mas cujo compasso real seria o binário

\footnotetext{
7 “Toda frase, período y subperíodo, tiene como soportes extremos dos tiempos fuertes - el primero y el último de los que abarca - que reciben, respectivamente, los nombres de 'ictus' inicial e 'ictus' final.”

${ }^{8}$ Tomemos o cuidado de relembrar que, em nossa nomenclatura, período e frase tiveram suas posições invertidas na estrutura em relação à terminologia de Zamacois. Portanto, nossa tradução pede licença para inverter os termos, com vistas a manter a coerência de nossa exposição.
} 
composto). A harmonização e as cadências são importantes fontes para se determinar o compasso real e, por extensão, os ictus.

Ainda com Zamacois, somos informados de que, segundo a posição que ocupam em relação ao ictus, os períodos, frases e semifrases podem ser:

- téticos: quando o ataque coincide com o ictus inicial;

- anacrúsicos: quando o ataque é anterior ao ictus inicial (a nota ou notas que antecedem o ictus inicial são a anacruse);

- acéfalos: quando o ataque se dá após o ictus inicial;

- masculinos: quando a terminação coincide com o ictus final;

- femininos: quando a terminação se dá após o ictus final (geralmente por meio de retardos e appoggiaturas) (ZAMACOIS, 1979, p. 13).

Esta classificação nos parece particularmente efetiva para uma perfeita compreensão das diferenças entre períodos ou frases acéfalos e anacrúsicos. A extensão dos períodos, frases e semifrases mede-se do ictus inicial ao final, contando-se o compasso inteiro no qual se encontra o ictus final e ignorando-se o compasso que contenha uma anacruse.

\section{3 - Procedimentos formais}

\subsection{1 - Considerações harmônicas}

As cadências harmônicas pontuam o discurso musical, indicando o término das frases e dos períodos; também o tema é normalmente delimitado por uma cadência. Essa pontuação pode indicar o término real do discurso ou criar a expectativa de uma continuação. A cadência perfeita ou final indica um término (de toda a peça ou de seção); a cadência imperfeita, semicadência ou cadência à dominante pontua, mas denota uma continuação. A cadência interrompida ou de engano (ou ainda cadência evitada), a despeito de sua utilização como ornamento e embelezamento (graças ao efeito surpreendente que pode gerar), tem uma finalidade claramente perceptível: 
anuncia uma cadência perfeita que não se cumpre, abrindo espaço para novas digressões; nisso reside sua mais destacada função estrutural.

As frases e semifrases podem ser classificadas, segundo o caráter impresso em seu final, em suspensivas (ou interrogativas) e conclusivas (ou afirmativas). Especificamente quanto à melodia, a classificação é orientada pela harmonia latente do trecho em questão, esteja esta harmonia escrita ou não. Desse ponto de vista, a classificação melódica e a harmônica podem não coincidir, e quando se trata de definições formais, a classificação harmônica tem primazia sobre a melódica.

Quanto à suspensividade ou conclusividade dos períodos, vale lembrar que seguidos períodos conclusivos tendem a causar desinteresse, retirando fôlego da estrutura, enquanto períodos suspensivos reiteram o interesse pela expectativa de continuidade que geram, afim à apresentação de novos conteúdos.

\subsection{2 - Considerações fraseológicas}

Dentro de um período, as frases não têm, todas, a mesma importância, mas dividem-se em principais e secundárias, estando portanto hierarquizadas. Normalmente há apenas uma frase principal em cada período, geralmente a que primeiro se faz ouvir, e que possui prioridade em ser reexposta. As frases secundárias, porém, têm função estrutural relevante, pois é por sua precisa construção e alocação que o caráter das principais se faz evidente. A respeito disso, a exposição de Zamacois não poderia ser mais qualificada:

As frases secundárias devem existir por e para as principais. Em conseqüência, se a falta de personalidade pode constituir um defeito para uma frase principal, o excesso pode [também] constituí-lo para uma secundária, posto que caiba que esta última [se assim constituída] empalideça o brilho da principal, ao invés de realçálo. ${ }^{9}$ (ZAMACOIS, 1979, p. 23) ${ }^{10}$

\footnotetext{
9 “Los períodos secundarios deben existir por y para los principales. En consecuencia, si la falta de personalidad puede constituir un defecto para um período principal, el exceso puede constituirlo para uno secundario, puesto que cabe que esto último empalidezca el brillo del principal, en vez de realzarlo.”

${ }^{10}$ Uma vez mais, nossa tradução pede licença para inverter os termos, com vistas a manter a coerência de nossa exposição.
} 
Um período pode ainda apresentar um fragmento não essencial em seu início, geralmente suprimível, a que chamamos Introdução. Se o mesmo se dá ao seu término, estamos diante de uma Coda. Muitos compositores, entretanto, conferiram relevância formal à introdução e à coda, fazendo-os reaparecer em desenvolvimentos ou reexposições, quiçá até como protagonistas de variações temáticas, o que lhes confere um novo status na composição, com efetiva significação estrutural (mais freqüentemente isso acontece à coda, então denominada “coda estrutural”). Em alguns casos, introdução e coda podem chegar a constituir tipos formais inteiros.

\subsection{3 - Construções simétricas e assimétricas}

Geralmente os períodos, frases e semifrases se compõem de estruturas simétricas, de duas ou três partes, ditas estruturas binárias ou ternárias, respectivamente. Dois ou três membros de uma seção geram a estrutura imediatamente superior. Assim sendo, é comum que duas conformações motívicas gerem uma semifrase, que duas semifrases dêem origem a uma frase, e que duas frases constituam o período. Eventualmente essas proporções podem ser dobradas. Disso resulta uma construção formal simétrica, comumente encontrada no repertório, baseada em estruturas binárias e normalmente denominada estrutura quadrada ou, simplesmente, “quadratura”. Se uma frase é oriunda de três semifrases, estaremos diante de uma estrutura ternária. Entretanto, se a próxima frase também contiver essa mesma estrutura, ambas formam um período de estrutura binária, garantindo a simetria.

O período pode ser composto de duas, três, quatro ou até mais frases. Normalmente a última frase é conclusiva, enquanto as anteriores podem ser suspensivas ou conclusivas. A construção mais comum, de duas frases, compõe-se de uma frase suspensiva seguida de uma conclusiva. Num período composto de três frases, a última é conclusiva, enquanto as duas primeiras tendem a ser suspensivas, de maneira a manter o interesse até a última frase; mas nada impede que tenham outra conformação. Um período de quatro frases assemelha-se a dois períodos de duas frases, embora a segunda frase possa ser suspensiva. Os períodos de cinco frases, ditos assimétricos, são normalmente o resultado da soma de duas e três (ou de três e duas) frases. Entretanto, se uma assimetria revelada num período se repete no próximo, a estrutura total se 
apresenta simétrica. Desta maneira, há a possibilidade de que uma assimetria presente em uma estrutura seja respondida por uma simetria num outro nível, normalmente mais elevado, o que garante o caráter simétrico de todo o trecho. São raros os casos de assimetrias geradas consecutivamente em semifrases, frases e períodos, levando à assimetria estrutural generalizada. Períodos formados por cinco, seis ou mais frases são escassos, mas são analisados segundo as premissas de simetria e assimetria que acabamos de explicitar.

Freqüentemente, um vazio rítmico que se forma entre o ictus final de uma seção (semifrase, frase ou período) e o inicial da próxima é preenchido por notas que os unem à maneira de uma anacruse. A esta conexão, aceitando a sugestão de Zamacois, denominaremos “soldadura” (ZAMACOIS, 1979, p. 24). As soldaduras não aumentam o número de compassos das seções (portanto não geram assimetrias), mas funcionam como elos entre as estruturas, favorecendo a manutenção da fluência do discurso. São particularmente eficazes ao final de uma frase ou período conclusivo que se liga a outra frase ou período de qualquer espécie.

\subsection{4 - Assimetria deliberada}

O excesso de simetria gerado pelas quadraturas pode resultar em desinteresse, dada a previsibilidade dos ciclos estruturais assim delineados. Isso leva os compositores a lançarem mão de recursos para produzir deliberadamente a assimetria. Desejada por produzir a quebra da monotonia, a assimetria apenas se constitui numa imperfeição da estrutura quando origina frases ou períodos ditos "mancos”, nos quais a falta de um compasso ou a presença de um compasso supérfluo é percebida como um desequilíbrio no conjunto. Segundo Zamacois, os principais expedientes para que uma assimetria deliberada se instale são:

- dupla função por elipse: o ictus inicial de uma frase ou período coincide com o ictus final precedente, suprimindo o lapso de tempo entre ambos, o que normalmente acarreta a eliminação de um compasso do conjunto;

- contração rítmica: algumas notas da frase ou do período têm suas durações reduzidas (freqüentemente à metade), originando a supressão de compassos. Se a contração se aplicar a toda a frase ou período a assimetria, obviamente, não será gerada; 
- dilatação rítmica: o inverso da contração rítmica, e a assimetria se manifesta pelo acréscimo de compassos;

- eco: alusão ao fenômeno acústico que o nomeia, ocorre quando um grupo de notas é imediatamente imitado; também aqui, se toda a seção é imitada, a assimetria não se manifesta;

- apêndice: compõe-se de fragmentos acrescidos à estrutura e que normalmente têm a função de reiterar uma determinada função harmônica;

- amplificação: partes de seções são amplificadas, normalmente por razões expressivas ou estruturais (por exemplo, para acomodar novas relações harmônicas em reexposições);

- redução: o inverso da amplificação, que pode se dar por cortes, insinuações ou recordações de frases ou períodos.

(ZAMACOIS, 1979, p. 36-40)

\section{4 - Tipos formais}

Historicamente, determinados padrões de organização do material musical tornaram-se recorrentes, por atenderem eficazmente a diversas demandas dos compositores (a teorização que abarca os tipos formais sucede, pois, à prática composicional). Sendo assim, certos gêneros musicais passaram a possuir uma estrutura básica, que foi sendo repetidamente transformada e enriquecida pelos compositores que subseqüentemente se utilizaram desta mesma estrutura. A partir de sua recorrência em determinados gêneros, tais estruturas tornaram-se arquétipos formais, momento em que transpuseram as categorias de gênero às quais estavam originalmente submetidas.

Faz-se necessário, portanto, uma distinção entre gênero e tipo formal. Embora os elementos estruturais de uma mesma forma apliquem-se a gêneros diferentes, ao referirem-se a determinado gênero estes elementos serão utilizados segundo critérios pertinentes ao respectivo gênero, mesmo que atentos ao cumprimento do padrão básico delimitado pelo tipo formal.

Graças a isso é que os compositores puderam valer-se de um mesmo tipo formal, a forma sonata, por exemplo, e aplicá-la a uma abertura de ópera, ao primeiro 
movimento de uma sinfonia ou de um quarteto de cordas, ou ainda ao primeiro movimento de uma peça de música de câmara, como um duo ou um trio.

No presente tópico deste trabalho, não abordaremos a utilização do tipo formal segundo o contexto de um gênero específico, mas faremos apenas uma breve descrição dos principais tipos formais, com vistas a fornecer os requisitos necessários à argumentação de nosso terceiro capítulo.

A crença de que a análise musical restrinja-se à determinação do tipo formal utilizado pelo compositor e à localização de suas seções numa obra tem freqüentemente reduzido o papel da análise. Entretanto, mesmo como passo inicial, uma delimitação esquemática dos tipos formais, ainda que possa, de momento, reiterar tal crença, se faz necessária. À investigação aprofundada, que mapeia intersecções e contradições, precede uma orientação básica, mesmo que redutiva. Desde que consciente, tal processo possibilita benefícios diversos.

\subsection{1 - Formas binária simples e ternária simples}

A forma binária simples possui duas partes claramente definidas e separadas por uma barra de repetição. Normalmente também há uma barra de repetição ao final da segunda parte. A elaboração temática é simples e o plano harmônico também: parte-se da tônica e vai-se até a dominante (ou a relativa maior no caso de tonalidades menores) ao final da primeira seção; a segunda seção retorna à tônica principal, após breves referências às regiões harmônicas de tonalidades vizinhas (aquelas pertencentes ao campo harmônico da tônica). Geralmente, o material enunciado no início da primeira parte aparece reiterado na segunda, apenas sublinhando a nova região harmônica. O contraste entre a primeira e a segunda parte é discreto. Esta é a forma de inúmeras danças que compõem as suítes, e podemos representá-la por: (a - b).

A forma ternária simples apresenta-se similar à binária, apenas possuindo três partes ao invés de duas. A terceira parte é uma retomada da primeira, sendo possível uma retomada literal ou levemente variada, que representamos por (a b a) ou (a b a'). Devido ao fato de que a primeira idéia será retomada, o contraste permitido à parte central é maior. Na intensidade deste contraste parece estar mesmo a origem desta pequena forma. À medida que o contraste da segunda parte de uma forma binária foi tornado mais intenso, foi necessário oferecer à memória uma repetição da primeira parte. Tal fato gerou, primeiramente, uma pequena retomada da primeira parte ao final 
da segunda, ainda sob apenas duas seções. Com tal prática sendo reiterada, acabou-se por introduzir a primeira parte praticamente completa dentro da segunda parte, apenas com alterações na cadência final (que agora deve afirmar a tônica). Pode-se considerar uma forma como ternária se houver uma clara repetição da música da primeira parte, seja esta repetição variada ou não. Há uma clara tendência dos compositores da segunda metade do século XVIII e início do XIX em incrementar o grau de variação da primeira parte quando ela é repetida, elaborando-a de modo a evitar uma repetição literal.

\subsection{2 - Minueto e trio}

Originalmente uma dança em compasso ternário, o minueto adentrou o universo da música instrumental como forma binária simples, no barroco. O minueto do classicismo, entretanto, é distinto, e foi utilizado como o terceiro movimento de sinfonias, quartetos de cordas e em algumas sonatas. Neste caso, possui uma estrutura ternária (minueto - trio - minueto), na qual cada seção é constituída por uma forma ternária simples. Seu esquema geral seria, portanto: [A (a b a), B (c d c), A (a b a)]. Na maioria dos casos, a volta ao minueto inicial é indicada com o Da capo ao final do trio. Schoenberg nos diz que “o caráter de um minueto pode variar do 'meramente cantarolável' ao ‘obstinadamente insistente’; mas, em geral, o caráter e o andamento são moderados”. (SCHOENBERG, 1991, p. 173).

O trio, também escrito em compasso ternário, tende a utilizar-se de região harmônica próxima à da tonalidade do minueto, sendo bastante comum estar sobre a homônima do minueto (menor, no caso do minueto estar em maior, e vice-versa). Embora sendo claro que é função do trio oferecer contraste ao minueto, é comum, entretanto, um parentesco temático entre ambos. É costume alterar-se a instrumentação no trio, conferindo-lhe um caráter mais próximo ao do que originalmente possuía (ser tocado por três instrumentos). Normalmente isso significa dedicar partes mais importantes, quase solistas, aos instrumentos de sopro.

Beethoven alterou o minueto e trio em algumas de suas sinfonias, acelerando seu andamento e tornando seu caráter ora mais circunspecto do que o original, ora extremamente jocoso. Tomou também a liberdade de alterar seu nome para Scherzo, cujo contorno formal é idêntico ao do minueto e trio. Com algumas exceções, utilizouse igualmente do compasso ternário. Schoenberg detectou importantes características associadas ao scherzo: 
O scherzo é, nitidamente, uma peça instrumental, caracterizada por acentuações rítmicas e tempos rápidos. A rapidez de movimento impede a freqüente mudança harmônica e a variação muito profunda das formas-motivo.

Com relação à estrutura, os scherzos dos grandes mestres possuem apenas uma coisa em comum: são formas ternárias. Eles diferem das pequenas formas ternárias, e do minueto, no sentido de que a seção intermediária é mais modulatória e mais temática. Em alguns casos, ocorre um tipo especial de seção contrastante modulatória, que se aproxima da elaboração (Durchführung) do allegro-desonata. (SCHOENBERG, 1991, p. 184).

\subsection{3 - Fuga}

O caráter imitativo do estilo contrapontístico tem raízes estéticas na mimese grega, nas quais a arte sempre é imitação, em algum nível, da natureza ${ }^{11}$. Do ponto de vista técnico, com a consolidação do triunfo do movimento contrário sobre o paralelo e o oblíquo (e o conseqüente incremento da independência das vozes), o contrapunctus medieval foi, durante a Renascença, submetido a intenso desenvolvimento e enriquecimento. Este processo terminou por favorecer uma série de procedimentos de escrita, baseados na fluência melódica e no cuidado em tratar as dissonâncias. Tais tratamentos, assentados sobre bases melódicas, intervalares e métricas (e que subsidiaram o nascimento do pensamento vertical, portanto harmônico), alçaram o contraponto até um estilo consideravelmente rebuscado, o imitativo.

Dentre as imitações, aquelas ao uníssono e à oitava forneceram subsídios para os cânones, porém sobre uma região modal ou tonal estática, à medida que as imitações à quinta produziram certa mobilidade excêntrica, em direção à região do quinto grau. A elaboração das referências a outras regiões (do campo harmônico) e o acréscimo de vozes colaboraram para que um procedimento padronizado fosse lentamente erigido. A assumpção destes procedimentos forjou uma escrita organizada, complexa, e de textura ricamente densa, permitindo à fuga florescer como peça musical completa.

Historicamente, as fugas de J. S. Bach representam a culminância do estilo contrapontístico, e não nos parece coincidência que mestres da envergadura de Mozart, Beethoven e Brahms, dentre outros, tenham utilizado fugas em muitas de suas obras,

\footnotetext{
${ }^{11}$ Voltaremos a este assunto em nosso terceiro capítulo.
} 
notadamente como elaborações últimas de materiais temáticos originalmente cunhados para a homofonia.

A questão de que a fuga não seja uma forma, mas um “procedimento”, não nos parece oferecer maiores problemas: ela é um procedimento que originou uma forma. Sob determinado foco, toda forma é nascida e permanece, simultaneamente, como um procedimento.

Fugas são normalmente divididas em três seções para fins de análise, e a nomenclatura destas seções, afortunadamente, é similar à das seções da forma sonata. Entretanto, dadas as características da escrita polifônica, nas quais o término de uma frase em uma voz é eclipsado pela entrada de outra voz antes que uma pausa se faça, a determinação das seções em uma fuga normalmente é mais delicada do que em outros tipos formais.

A exposição é construída pela entrada sucessiva de todas as vozes para as quais a fuga está escrita. A entrada do sujeito (ou $d u x$, antecedente, proposta, tema) é seguida pela resposta (ou comes, conseqüente, contestação), e, até que todas as vozes exponham ou o sujeito ou a resposta, não se considera encerrada a exposição. Ao final da entrada da segunda voz (resposta), por vezes se faz necessário um curto trecho modulatório, que reconduz à tonalidade principal (vindo da região do quinto grau), para que a terceira voz apresente normalmente o sujeito. Este trecho é chamado pequeno episódio ou pequeno divertimento. O contraponto escrito para o sujeito ou para a resposta, se for construído como inversível e mostrar-se recorrentemente utilizado, é dito contra-sujeito. É possível a utilização de mais de um contra-sujeito, e o seu número máximo, por razões técnicas, é inferior ao número das vozes reais em uma unidade.

O desenvolvimento caracteriza-se pela alternância entre episódios e entradas intermediárias (termos sujeitos a variações de nomenclatura). Os episódios ou divertimentos são seções modulatórias, construídas normalmente a partir dos próprios elementos utilizados na exposição, que têm por função alcançar regiões harmônicas desejadas. As entradas intermediárias são pseudo-exposições realizadas sobre novas regiões harmônicas, nas quais não é necessário que todas as vozes apresentem o sujeito ou a resposta, dado seu caráter ser mais transitório do que o da exposição ordinária. O número de episódios e entradas intermediárias de que é feito o desenvolvimento fica a cargo do compositor, mediante as considerações de proporção julgadas oportunas. Há uma tendência, geralmente verificável, de que os episódios construam-se a partir de crescente complexidade, favorecendo o aparecimento de seqüências melódicas 
porventura cromáticas e progressões harmônicas mais corajosamente dissonantes. É no curso do desenvolvimento que inversões, retrógrados, ampliações e contrações mormente são aplicadas ao sujeito e à resposta (e eventualmente ao contra-sujeito). Acrescentemos que o último episódio deve anunciar o retorno da tonalidade principal, preparando a reexposição.

A reexposição caracteriza-se pela sucessiva entrada das vozes, novamente sobre a tonalidade principal, mas é mais livremente construída. Normalmente são encontradas, nesta seção, imitações nas quais a distância entre as entradas do sujeito e da resposta é drasticamente reduzida. É o stretto, cuja função é a condensação temporal dos materiais, expressão nuclear de suas essências, dramaticamente reverberada. A presença do stretto não é obrigatória (embora desejável), e mesmo a construção de mais de um stretto não é inoportuna. Na verdade, estas são questões da alçada do compositor. Para o efetivo término da fuga, geralmente um baixo pedal estabiliza a tonalidade principal (embora o pedal por vezes apresente-se sobre a dominante, ou sobre ambas), e sobre ele o sujeito normalmente acena pela última vez, já construindo a coda.

\subsection{4 - Tema com variações}

Como o próprio nome indica, trata-se de tecer variações sobre um tema proposto. O tema, propriamente dito, pode ser um simples período, ou uma forma binária simples, ou ainda uma ternária simples. O modelo para esta forma é: $\mathrm{A} \quad \mathrm{A}^{1} \mathrm{~A}^{2}$ $\mathrm{A}^{3}$..., prosseguindo até que o compositor julgue terminado o ciclo de variações que desejava propor.

As maneiras de variar o material são incontáveis, mas algumas manifestam-se mais correntemente. Dentre estas, destaquemos as variações: melódicas, rítmicas, harmônicas, de compasso e de andamento, de modo, de tessitura, de texturas, imitativas, de instrumentação, por espelhamento, e outras. Tais variações podem ser combinadas, pois não são excludentes.

É costume acrescentar-se uma coda para terminar, ou construir a última variação à maneira de uma coda. Eventualmente o próprio tema reaparece em sua forma original para finalizar a obra. Também não raras são as utilizações de uma fuga como uma das variações finais, visto ser esta uma elaboração contrapontística privilegiada do tema. É importante notar que a variação simultânea de vários parâmetros pode tornar-se um 
empecilho para a inteligibilidade, pois que o tema pode não ser reconhecido em nenhum de seus contornos fundamentais.

Uma forma de variação específica, tida como “variação contínua”, é conhecida como "basso ostinato", na qual, sobre uma linha obstinadamente repetida pelos instrumentos graves ou pela voz mais grave, são tecidas subseqüentes variações melódicas e contrapontísticas, geralmente de complexidade crescente.

Também a passacaglia e a chaconne são consideradas “variações contínuas”, aparentadas ao basso ostinato. As diferenças entre ambas carecem de um consenso entre os tratadistas, mas assim poderíamos tentar distingui-las: na passacaglia o tema está normalmente no baixo, embora não seja impossível que se apresente em outras vozes; já na chaconne, o que é sempre mantido é o plano harmônico originalmente inerente ao tema, mesmo que, em determinados momentos, o próprio tema não esteja presente.

Se o tema com variações constitui-se na obra completa, tende a ser mais longo e com maior número de variações. Se, ao contrário, é um dos movimentos de uma obra, tende a possuir menos variações, de maneira a não romper as proporções de toda a obra.

Sobre a estrutura do tema, Schoenberg nos ensina que:

Há temas que facilitam e outros que dificultam o desenvolvimento de variações. Antes de tudo, as variações são repetições que tornar-se-iam intoleráveis se não houvesse uma constante reestimulação do ouvinte. Se o tema contém um excesso de elementos, mesmo que sejam interessantes, sobra pouco espaço para as adições que um tema simples propicia. (SCHOENBERG, 1991, p. 202)

Embora os temas devam ser simples, a composição de temas adequados para variações não é tarefa simples. Schoenberg nos relembra que "muitas variações clássicas estão baseadas nas melodias populares ou folclóricas (...)”, enquanto outras “(...) estão calcadas em temas dos próprios compositores”; acrescentando logo mais à frente que “não é fácil escrever um bom tema original para variação”, e que devemos, portanto, valermo-nos de temas de consagrados compositores. (SCHOENBERG, 1991, p. 202-3)

Apesar das variações propostas, as proporções gerais e os apoios estruturais do tema são mantidos, de forma que as variações mantenham qualidades formais análogas ao tema. 
Uma rica e profunda abordagem sobre tema e variação nos é dada pelo professor Ricardo Rizek. Embora a citação seja longa, julgamos relevante transcrevê-la na íntegra:

(...) se trata de uma forma dinâmica, envolvendo transformações que entrelaçam mudança e permanência no transcurso inexorável do fluxo do tempo. Como se houvesse um páthos nessa "música” cósmica (quiçá um páthos do próprio tempo enquanto vertente fundamental do cosmos), ela transmite-nos um sentimento nostálgico, ou seja, nela (ou em nós, ou nela através de nós) encontramos um anseio de retorno, após a peregrinação pelas múltiplas variações, ao tema original. O aparente anseio deste tema ou estrutura de resgatar-se responde a um outro, o de entregar-se à atualização das transformações nele contidas em estado latente. Pois, o próprio tema, em toda música bem construída, orientada pelo princípio de variação, já deve conter em si mesmo as motivações estruturais que potencialmente conclamam as transformações que se atualizarão.

Por ensejar, através de suas mais íntimas articulações de estrutura, um movimento de perda de sua configuração inicial, é mais do que justo, então, subordinar tal desejo à necessidade de um recolhimento final, ou seja, de um resgate da dimensão temática originária para além da própria configuração original. Atualizado, qualificado e enriquecido pela totalidade do ciclo de variações, este resgate, quando suficientemente desvelado, por e para nós, como um projeto a ser realizado, revelase como a verdadeira causa da própria perda inaugural. (RIZEK, prefácio para SANTOS, 2000, p. 17-18.)

\subsection{5 - Formas rondó}

\subsubsection{1 - Rondó simples}

Também originada da dança, a forma rondó ${ }^{12}$ apresenta-se como a alternância entre um mesmo refrão (ou estribilho) e diferentes estrofes (ou coplas). Cada nova apresentação do refrão pode ser literal ou variada, enquanto as estrofes intercaladas aos refrões tendem a introduzir, a cada vez, um novo material temático. É característico do rondó ter um tema claramente definido, a partir de um perfil melódico-rítmico de caráter preponderantemente leve e alegre.

\footnotetext{
${ }^{12}$ Do francês rondeau, cuja origem deve-se às antigas cantigas e danças “de roda”.
} 
Dependendo do número de estrofes, a forma pode ser representada por A B A', ou A B A' C A', ou A B A' C A'” D A', ', e assim sucessivamente. Formas derivadas podem apresentar-se como, por exemplo, A B A' C A'” B' A','. Claro está que as estrofes que se intercalam aos refrões funcionam como contrastes sob diversos possíveis aspectos: melódico, harmônico, rítmico, de textura, de instrumentação, e outros.

Intersecções entre a forma rondó e outras são feitas. Especialmente no barroco, reconhece-se a utilização do "minueto em rondó", no qual, ao minueto, se intercalam dois ou mais trios (ou ainda outras danças), originando um rondó à maneira de um minueto.

Outras intersecções geraram tipos formais mais complexos, chamados "formas rondó". Os rondós descritos anteriormente seriam, então, pertencentes às "pequenas formas”, enquanto os que estudaremos agora pertencem às "grandes formas”.

\subsubsection{2 - Forma lied}

A primeira dessas formas rondó é chamada de “forma andante” ou "forma lied", e está freqüentemente associada ao segundo movimento de sinfonias, quartetos de cordas e em algumas sonatas para piano ${ }^{13}$. Comumente apresenta-se sob dois padrões básicos: A B A ou A B A B'.

No primeiro caso, A B A, tanto A quanto B tendem a ser constituídos de pequenas formas ternárias ( $\mathrm{a} b$ a). O plano harmônico pressupõe que $\mathrm{B}$ esteja em tonalidade diferente de A e da seção b (interna ao A), evitando uma dupla visita a uma mesma tonalidade vizinha. Todo o $\mathrm{B}$, embora também seja pequena forma ternária, possui caráter contrastante e menos estável do que A.

No segundo caso, A B A B', as pequenas formas ternárias também tendem a formar as unidades maiores, mas o plano harmônico se altera, pois o B final normalmente dobra-se à tonalidade do $\mathrm{A}$, enquanto o B intermediário pode se dar nas tonalidades vizinhas. Transições, variações motívicas e codas podem ser encontradas nos dois tipos citados.

\footnotetext{
${ }^{13}$ Embora nem sempre a "forma lied” esteja inserida nos tópicos de formas rondó, julgamos acertado classificá-la assim.
} 


\subsubsection{3 - Rondó sonata}

Temos ainda a forma ABA C ABA, chamada por Schoenberg de "grande forma rondó”. (SCHOENBERG, 1991, p. 236) Sua principal diferença é o caráter contrastante e alongado da parte $\mathrm{C}$, que tende a ser construída de maneira similar à de um trio de scherzo. O primeiro e o último ABA tendem a não ser tão longos de maneira que, se cada ABA fosse visto como uma única seção, suas proporções não seriam muito maiores do que as da parte C. Uma transição se faz necessária entre a seção A e a seção B em sua primeira aparição, mas não é obrigatória em sua última, pois que o B tende a ser então submetido à tonalidade principal. O caráter deste grande rondó tende a ser leve, alegre e ligeiro, aparentado ao caráter das danças, e é normalmente utilizado como último movimento de sinfonias, quartetos e sonatas.

Esquematicamente muito aparentado a esta grande forma rondó é o "rondó sonata”, organizado sob o esquema ABA C' ABA, e cuja diferença principal em relação ao anterior é que sua seção C' possui o caráter de um desenvolvimento ou elaboração (Durchführung). Em relação à forma sonata, notemos que o primeiro tema aparece por duas vezes, tanto na primeira seção quanto na segunda. É muito utilizado como movimento final de sinfonias, concertos, quartetos e sonatas.

Schoenberg ainda cita o "grande rondó sonata” (ABA CC’ ABA), no qual duas seções C são utilizadas, contendo tanto o trio do scherzo quanto o desenvolvimento da sonata. (SCHOENBERG, 1991, p. 229) Zamacois apenas utiliza rondó simples e rondó sonata. (ZAMACOIS, 1979, p. 196-199) Como meio termo, fiquemos com um resumo que assim pode ser enunciado: rondó simples, forma lied e rondó sonata.

\subsection{6 - Forma sonata}

Considerada a principal forma da música tonal, a forma sonata ou "allegro de sonata” possui em sua flexibilidade o grande trunfo de seu sucesso. Serve como primeiro movimento para sinfonias, concertos, quartetos, sonatas, duos e trios, aberturas e outros. Sua característica principal é o caráter elaborativo de sua segunda seção. Seu plano formal também é ternário: exposição, elaboração ou desenvolvimento, e reexposição ou recapitulação. 


\subsubsection{1 - Exposição}

A exposição afirma dois temas ou grupos de temas, o principal e o secundário. O tema principal pode ser um grande período ou até uma livre reunião de temas afins, sutilmente conectados. Este primeiro tema está na tonalidade principal. Seu contorno é normalmente definido. Quando há um grupo de temas, o retorno ao primeiro deles normalmente anuncia a entrada da transição (ou ponte).

A principal função da transição é realizar a modulação à tonalidade na qual o segundo tema será expresso, normalmente a dominante (ou a relativa maior no caso de tonalidades menores). Entretanto, ela não apenas conduz a um tema contrastante, senão que ela mesma representa já um contraste. Se a transição é realizada a partir dos materiais do tema principal, seu contraste é essencialmente harmônico. Às vezes, porém, a transição é construída sobre um tema independente, o que acentua seu contraste, pois que harmônico e simultaneamente temático, embora instável. Schoenberg procurou delimitar e caracterizar a transição:

A estrutura de uma transição inclui, basicamente, quatro elementos: estabelecimento da idéia transitória (através de uma repetição freqüentemente seqüencial), modulação (em vários graus), liquidação das características motívicas e estabelecimento do acorde "anacrúzico" conveniente. (SCHOENBERG, 1991, p. 216)

O grupo de temas secundários existe por contraste ao principal. Normalmente, o contorno de um tema secundário é mais difuso, embora se façam evidentes os contrastes harmônico e temático. Tal caráter difuso favorece aqui, mais do que no tema principal, o surgimento de um grupo de temas, ao invés de um tema único. O tema secundário normalmente deriva do principal em algum aspecto, mesmo que oculto (o que evidencia sua subordinação), mas simultaneamente se lhe opõe por contrastes. O tantas vezes referido caráter lírico do segundo tema não se constitui em regra, mas em procedimento característico do romantismo e do classicismo. No plano harmônico, o grupo de temas secundário normalmente está sobre a dominante se a tonalidade principal for maior, e na relativa maior se a principal for menor. Mas isto não é uma regra, apenas um procedimento deveras recorrente. Sobre a origem dos temas secundários, Schoenberg assim se manifestou: 
Os temas secundários devem ter se originado como condensações e estabilizações internas de um movimento modulatório contrastante. No início não eram senão episódios, e, mais tarde, tornaram-se seções secundárias definidas, estabelecendo um final numa região vizinha (como a dominante ou a relativa maior). (SCHOENBERG, 1991 p. 227)

Normalmente é acrescida, ao final da exposição, uma codetta que encerra a exposição na tonalidade dos temas secundários. Uma introdução antes da exposição do primeiro tema é às vezes incluída, e, se ela existe, normalmente está em andamento lento (adagio) para preparar o allegro que se segue.

\subsubsection{2 - Elaboração ou desenvolvimento}

A principal característica da elaboração é ser harmonicamente instável e utilizarse dos temas principal e secundário (ou dos fragmentos destes temas) para levá-los a realizar o que neles estava já potencialmente anunciado. Diversas regiões harmônicas são visitadas, e o material temático pode ser utilizado em qualquer ordem.

Também não é necessário que todo o material temático seja elaborado, e livremente o compositor pode eleger quais os materiais que deseja utilizar e em que ordem. Nada impede, por exemplo, que ele utilize mais elementos do segundo tema do que do primeiro, o que, em tese, não seria esperado. Os elementos da transição também podem ser chamados a comparecer à elaboração, e notemos que já se apresentam adequadamente modulantes.

Os acordes errantes, que servem simultaneamente a várias tonalidades (por enarmonização ou reinterpretação), são bem vindos na elaboração, e há uma tendência (e não mais do que uma tendência) a visitar as regiões mais à esquerda do círculo das quintas da tonalidade principal, provavelmente para contrabalançar a modulação à direita manifesta na exposição.

Determinadas regiões harmônicas podem ser momentaneamente afirmadas para logo serem removidas. Progressões harmônicas cromáticas podem ser utilizadas para amparar seqüências melódicas modulantes. Traços de um material temático podem converter-se em figuras de acompanhamento que amparam outro material temático, gerando possíveis sobreposições. O roteiro da elaboração não está determinado, é o 
compositor quem decide que caminho vai tomar. Ao final desta seção, entretanto, deve ser providenciado um retorno à tonalidade principal, preparando a reexposição. Tal retorno pressupõe a liquidação dos materiais elaborados e uma retenção harmônica sobre a dominante da tonalidade principal, o que muitas vezes é realizado por um pedal sobre esta dominante:

O final da elaboração deve ser tratado de modo a neutralizar o impulso modulatório, assim como a liquidar as obrigações motívicas criadas nesta seção, e, ao mesmo tempo, prepara o ouvinte para o retorno da recapitulação. (SCHOENBERG, 1991, p. 253)

\subsubsection{3 - Reexposição ou recapitulação}

A reexposição novamente apresenta os temas principal e secundário, sendo que o secundário dobra-se aqui à tonalidade principal do movimento. Disso poderia deduzirse que a transição não se faria mais necessária, mas a verdade é que os compositores a utilizam e, muito provavelmente, porque seja ela, agora, uma das únicas possibilidades de obter contraste. Muito interessantes são as técnicas utilizadas pelos compositores para inventarem transições que emulem um caráter modulante, ainda que iniciem e terminem sobre uma mesma tonalidade.

A reexposição suporta (e deseja) também ligeiras alterações nos temas, tais como elisões, amplificações ou reduções, simplificações ou curtas elaborações contrapontísticas. Tal fato sublinha a diversa expressão que os temas porventura emanem, graças à memória das profundas transformações a que foram submetidos na elaboração. Tais resíduos manifestam-se num caráter regozijante que os temas principal e secundário parecem afirmar na reexposição, o que deve ser resultado da manipulação a que foram submetidos e também da sua deferência final a um único centro tonal.

Uma coda é, na maioria das vezes, utilizada para encerrar o movimento. Embora uma generalização não seja possível, é comum encontrar-se nas codas uma pequena digressão harmônica que relembre as modulações realizadas, bem como um ou ambos os temas à maneira de citação longínqua ou incompleta. Eventualmente, o próprio tema principal pode conduzir-se sobre os últimos acordes da cadência final. 
O plano formal da forma sonata pode ser assim resumido:

- Exposição: tema principal (tônica), transição, tema secundário (dominante ou relativa), codetta;

- Elaboração ou desenvolvimento: livre manipulação dos temas e digressões harmônicas;

- Reexposição: tema principal (tônica), transição , tema secundário (tônica), coda.

Citemos ainda a conclusão de Schoenberg, pela importância vital que terá em nosso capítulo subseqüente, sob diversos aspectos:

O significado da forma enquanto organização de idéias musicais inteligíveis, logicamente articuladas, é particularmente evidente nas composições que aqui citamos. É também evidente (...) que as formas mais desenvolvidas não podem ser construídas pela simples união de "tijolos” musicais, ou pela "cimentação" das idéias em molduras predeterminadas. (SCHOENBERG, 1991, p. 257) 


\section{Capítulo 3 - Retórica Musical}

\section{1 - Da retórica à retórica musical}

A aplicação dos princípios da retórica à música remonta à utilização grega desta última como ferramenta pedagógica e como instrumento para a devida e correta expressão das emoções. Assim caracterizada, a música foi indicada por Platão como instrumento privilegiado, junto à ginástica, para o desenvolvimento das virtudes nos jovens atenienses. Quem nos fala é Sócrates, pela pena de Platão:

É, decerto, por esta razão, meu caro Glauco, que a educação musical é a parte principal da educação, porque o ritmo e a harmonia têm o grande poder de penetrar na alma e tocá-la fortemente, levando com eles a graça e cortejando-a, quando se foi bem educado. (PLATÃO, 1997, p. 95)

Mas a música necessita estar devidamente aliada à ginástica: “(...) Depois da música é pela ginástica que é preciso educar os jovens. Pois a melhor ginástica não é irmã da música simples de que falávamos há pouco?” (PLATÃO, 1997, p. 97, 98) O arremate é preciso:

Existem na alma dois elementos: a coragem e a sabedoria; um deus, direi eu, deu aos homens duas artes, a música e a ginástica; não as deu para a alma e para o corpo, a não ser acidentalmente, mas para aqueles dois elementos, a fim de que se harmonizem entre si, sendo estendidos ou soltos até o ponto conveniente. (...)

Aquele, pois, que associa com mais beleza a ginástica à música e, com mais tato, as aplica à sua alma, é músico perfeito e possui a ciência da harmonia muito mais do que aquele que afina entre si as cordas de um instrumento. (PLATÃO, 1997, p. 107)

Para os gregos, o termo música incluía, intrinsecamente, a linguagem, o que pode ser ilustrado se atentarmos para o fato de que a língua grega possuía durações e alturas definidas para cada vocábulo, fato que a tornava uma "língua entoada”. Corroboremos nossa assertiva com Neubauer: 
O conceito grego de musiké abrangia ambos, música e linguagem, porque a música fundamentava-se sobre o invariável comprimento e entonação das sílabas gregas. Uma comparável imitação musical de palavras não é possível nas modernas línguas européias, pois nestas o comprimento e a entonação de uma sílaba dependem da particular ênfase semântica que esta receba no contexto. ${ }^{14}$ (NEUBAUER, 1986, p. 22)

Também durante toda a Idade Média música e texto estiveram indissoluvelmente ligados para servir aos princípios da contemplação e adoração religiosa. As linhas gerais desta adequação entre música e texto assentavam-se, tanto na Antigüidade Grega como na Idade Média, sobre a escolha dos modos e ritmos (e acompanhamento instrumental, no caso dos gregos) que convinham a uma determinada e desejada expressão.

Tudo indica que devemos a Boecius (480-524), filósofo e matemático romano e à sua De institutione musica ter a teoria musical desenvolvido-se paralelamente a suas relações com a retórica. Também a ele, principalmente, devemos a retomada da teoria musical grega e sua permanência até meados do século XVI. Assim Bartel se manifestou acerca da importância de Boecius:

Através de seu trabalho, o conceito pitagórico de música como uma disciplina matemática ocupou firmemente seu espaço no pensamento escolástico medieval, estabelecendo a primazia da ciência especulativa sobre a arte perceptiva-sensorial do fazer musical. ${ }^{15}$ (BARTEL, 1997, p. 11)

A idéia de música como arte retórica assenta-se, portanto, sobre a persistente metáfora de música como linguagem. Tornou-se particularmente fecunda na Renascença e no Barroco, sob o conceito de música poética. O compositor, musicus poeticus, trabalha suas obras da mesma maneira como um orador que manipula a linguagem verbal, ou seja, concatenando idéias que se apresentem capazes de persuadir.

\footnotetext{
14 “The Greek concept of musiké covered both music and language, because music was based on the invariable length and pitch of Greek syllables. No comparable musical imitation of words is possible in the modern European languages, because in these the length and pitch of a syllable depend on the particular semantic emphasis it receives in context.”

15 "Through his work the Pythagorean concept of music as a mathematical discipline became entrenched in medieval scholastic thought, establishing the primacy of the speculative science over the sensuously perceivable art of music making.”
} 


\section{2 - As septem artes liberales: trivium e quadrivium}

Para melhor entender o caminho das relações que música e retórica, como artes relacionadas, percorreram entre a Antigüidade Grega e o século XVIII, sigamos a breve exposição de Gertrud Mersiovsky. Com ela aprendemos que

O sistema educativo, intitulado septem artes liberales, tinha sua origem na Antigüidade. Permaneceu ao longo dos séculos, com ampliações e algumas modificações, até o final do século XVIII. Hippias de Elide (V/ IV século a.C.) é tido como o criador do sistema educativo, baseado nas artes liberales. O saber, como unidade de técnicas múltiplas (pleistai téchnai, Platão), é liberal, porque se dedica a atividades dignas do homem, dando-lhe honra e glória. (MERSIOVSKY, 2005, p. 104)

Foram, portanto, as sete artes liberais, organizadas à maneira de um abrangente currículo acadêmico, que transpuseram os séculos (aproximadamente dez) e impuseramse como portadoras dos conhecimentos e saberes que a ocidentalidade logrou preservar.

As septem artes liberales dividem-se em quadrivium e trivium:

- quadrivium: aritmética, música, geometria e astronomia

- trivium: gramática, retórica, dialética (ou lógica)

Já a música se divide em:

- música teórica (teórica, especulativa, contemplativa): ars musica

- música prática, que por sua vez se dividia em outras duas:

- música modulatória: ars cantus, ars executionis

- música poética: ars compositionis

No quadrivium (quadruplex via ad sapientiam) estão as disciplinas baseadas no número. Este “quádruplo caminho para a sabedoria” é racional, pitagórico, cosmológico, e a presença da música no quadrivium explica-se por suas características matemáticas de proporção e razão. Assim entendida, a música é matemática acusticamente manifestada, conforme já afirmamos no capítulo 1. Entretanto, essa é a face especulativa, contemplativa da música, a musica theorica. 
No trivium (triplex via ad eloquentiam, arte discendi), estão as disciplinas da palavra, portanto, da linguagem. A musica practica (ars cantus, ars compositionis), portanto, é também afim ao trivium sob este aspecto, embora permaneça atrelada fundamentalmente ao quadrivium.

Esta natureza dual da música, transitando entre o trivium e o quadrivium, constitui-se em uma de suas mais ricas características. Música é matemática e música é linguagem. E aqui estamos diante ou de uma metáfora significativamente mais profunda e elaborada ou abandonamos, já, o plano simbólico; houvesse morada na qual a poética não fosse incongruente ao campo conceitual, mas ambos desejassem unir-se em síntese de patamar mais elevado, estaríamos a repousar nela agora.

Se é pela musica theorica que matemática e música se unem, é via musica practica que retórica e música igualmente o fazem, e compreender tal afirmação é de crucial importância para aceitar a natureza múltipla da disciplina música.

Nas palavras de Mersiovsky:

A relação entre música e retórica conhece-se desde a Antigüidade, estabelece-se pelo sistema das artes liberales, revigora-se como retórica musical no século XVI, pela redescoberta de Aristóteles, Cícero, Quintiliano e pela reforma luterana no espaço do Centro e Norte da Alemanha, onde se torna fundamento e exigência da composição, até o fim dos tempos de Bach.

As Institutiones oratoriae de Quintiliano foram fundamentais para as obras teóricas dos séculos XVI a XVIII na Alemanha luterana e aplicadas nas Escolas de Latim e universidades. O músico instruído, cantor e compositor, teria freqüentado estas instituições e absorvido vigorosamente esses ensinamentos. (MERSIOVSKY, 2005, p. 105)

A partir do fim da Idade Média, graças ao acentuado desenvolvimento cultural e artístico (e que inclui a retomada dos valores gregos) que caracteriza o Renascimento, assistiremos ao aparecimento de uma série de tratados sobre retórica e música, especialmente na Alemanha luterana dos séculos XVII e XVIII. Tal preponderância germânica foi assim comentada por Bartel:

A rigorosa aplicação da terminologia e metodologia retóricas à análise musical e à composição permaneceu predominantemente como um fenômeno do Barroco germânico. Embora princípios retóricos tenham influenciado a composição musical 
na Itália, França e Inglaterra, somente na Alemanha este desenvolvimento culminou na entusiástica adoção e adaptação da terminologia, dos métodos e das estruturas retóricas. ${ }^{16}$ (BARTEL, 1997, p. ix)

\section{3 - Música poética e os tratados: ars compositionis}

A partir do estudo de Dietrich Bartel em Musica Poetica, podemos listar os mais importantes destes tratadistas e seus respectivos tratados, que são os seguintes:

Joachim Burmeister (1564-1629)

- Hypomnematum musicae poeticae (1599)

- Musica autoschediastike (1601)

- Musica Poetica (1606)

Johannes Nucius (ca. 1566-1620)

- Musices Poeticae (1613)

Joachim Thuringus (?-?)

- Opusculum Bipartitum (1624)

Athanasius Kircher (1601-1680)

- Musurgia Universalis (1650)

Christoph Bernhard (1628-1692)

- Tractatus compositionis augmentatus (ca. 1660)

- Ausführlicher Bericht vom Gebrauche der Con - und Dissonantien (?-?)

Wolfgang Caspar Printz (1641-1717)

- Phrynis Mytilenaeus (1676-79)

\footnotetext{
16 "The rigorous application of rhetorical terminology and methodology to musical analysis and composition remained a predominantly German Baroque phenomenon. While rhetorical principles influenced musical composition in Italian, French, and English circles, only in Germany did this develop into an enthusiastic adoption and adaptation of rhetorical terminology, methods and structures.”
} 
Johann Georg Ahle (1651-1706)

- Sommer-Gespräche (1695)

Tomás Baltazar Janovka (1669-1741)

- Clavis ad Thesaurum magnae artis musicae (1701)

Mauritius Johann Vogt (1669-1730)

- Conclave thesauri magnae artis musicae (1719)

Johann Gottfried Walther (1684-1748)

- Praecepta der musicalischen Composition (1708)

- Musicalisches Lexicon (1732)

Johann Mattheson (1681-1764)

- Der vollkommene Capellmeister (1739)

Meinrad Spiess (1683-1761)

- Tractatus musicus compositorio-practicus (1745)

Johann Adolf Scheibe (1708-1766)

- Der critische Musikus (1745)

Johann Nikolaus Forkel (1749-1818)

- Allgemeine Geschichte der Music (1788-1801)

(BARTEL, 1997, p. 93-164)

Ultrapassa as finalidades desta pesquisa descrever pormenorizadamente o conteúdo de cada um destes importantes estudos, contudo podemos resumir, em linhas gerais, os assuntos de que tratam.

Temas idênticos serão reconhecidos nos diversos tratados, ainda que em alguns encontremos todos eles e apenas alguns em outros. Os assuntos principais são o caráter 
divino da música (de acordo com a visão luterana), sua importância enquanto ferramenta pedagógica e suas relações com a retórica. Nesta última parte, que é a que nos importa agora, duas grandes linhas se apresentam: a visão do processo criativo (composicional) segundo as regras da retórica e a utilização das figuras retóricas (figurenlehre). Como a primeira abarca a segunda em uma de suas partes, estudemo-las a partir da visão do processo criativo.

\section{4 - Retórica e processo criativo}

A divisão da matéria retórica ou processo estrutural retórico, conforme já abordamos no primeiro capítulo deste estudo, compreende cinco partes: inventio, dispositio, elocutio (ou decoratio), memoria e pronunciatio (ou actio). Assim estruturado, o processo retórico foi considerado imprescindível pelos oradores gregos e latinos, bem como para os compositores do século XVIII (especialmente na Alemanha, mas daí irradiando-se por toda a Europa). Vamos estudar essas partes mais detidamente agora, conforme prometêramos.

\subsection{1 - Inventio}

Considerado o passo inicial, a inventio é a determinação do tema, assunto, ou ainda do "tópico" sobre o qual se vai discorrer (compor). Este tópico é o fundamento sobre o qual se construirá a representação e evocação do afeto correspondente. Essa inventio é também o momento no qual a imaginação criadora percebe, reconhece e seleciona os materiais que se apresentam próprios para a persuasão que se irá dispor. Tal processo vai ao encontro da definição aristotélica para retórica:

Assentemos que a Retórica é a faculdade de ver teoricamente o que, em cada caso, pode ser capaz de gerar a persuasão. Nenhuma outra arte possui esta função, (...). Mas a Retórica parece ser capaz de, por assim dizer, no concernente a uma dada questão, descobrir o que é próprio para persuadir. (ARISTÓTELES, s.d., p. 33)

Do ponto de vista musical, significa a determinação de uma idéia central (melodias, temas) e da tonalidade mais adequada para exprimi-la; a definição geral do 
andamento e dos metros principais, bem como dos timbres preponderantes. É importante notar que a definição destes parâmetros precede o grafismo na partitura, a escrita propriamente dita (que terá lugar na dispositio e na elocutio).

Devido ao fato de que essas escolhas iniciais não permitem equívocos, sob pena de resultarem numa composição que não expresse o afeto desejado, inventio é considerada a etapa na qual o gênio e a criatividade individuais mais intervêem. Para auxiliar os compositores havia, claro, indicações de perfis melódicos, tonalidades, metros e ritmos básicos mais afeitos a determinados assuntos, desenvolvidas durante todo o século XVII e ampliadas durante o século XVIII. Entretanto, a combinação destes elementos num todo coerente não é tarefa que se possa transmitir integralmente por meios técnicos.

Quando havia texto, este determinava o afeto que devia ser comunicado pela música (sendo a inventio o momento apropriado para essa realização), e era comum a noção de que a correta música “dava vida às palavras”. Estas forneciam o entendimento racional da mensagem, já a música garantia o páthos, passio ou affectus. Recordemos a acepção que páthos e passio possuíam para os gregos e latinos: é antes algo que está em nós e nos possui, sendo os homens passivos, passíveis de serem "afetados”.

Quando o texto não estava presente (o que se tornou mais freqüente durante o século XVIII), cabia aos próprios compositores a escolha do affectus a ser utilizado, o que dava margem à ampla utilização dos tópicos, ou seja, da determinação de quais elementos poderiam gerar as idéias que seriam adequadas à finalidade pretendida na composição musical.

Assim como para Aristóteles os "lugares” representavam o ponto de partida para saber-se, de antemão, se era possível derivar um entimema, tais lugares ou tópoi determinavam, em música, o que era passível de ser utilizado com vistas à persuasão desejada, constituindo-se, portanto, num caminho privilegiado através do qual o compositor guiava sua imaginação, na busca de idéias pontuais. A derivação de uma idéia a partir de outra já utilizada e mesmo a reelaboração de uma mesma idéia eram possibilidades amplamente aceitas e corroboradas pelos mais importantes tratadistas, como Mattheson. 


\subsection{2 - Dispositio}

Dispositio é a parte do processo na qual as idéias geradas na inventio serão dispostas. Para que essa disposição seja orientada e organizada, há uma subdivisão tradicional da dispositio em seções. Esta subdivisão sofreu pequenas variações desde a Antigüidade, sendo hoje aceita como padronizada a divisão já por nós enunciada no capítulo primeiro, que agora retomamos para aplicá-la à música. A dispositio equivale, ressaltemos, ao início do processo de escrita da partitura no processo composicional, são suas linhas gerais, esboços fundamentais.

\subsubsection{1 - Exordium}

O exordium, funcionando como uma espécie de introdução ao tema, silencia o auditório e prepara os ânimos dos ouvintes, solicitando sua atenção para o que virá. É da alçada do exordium conquistar a atenção da platéia. Musicalmente falando, equivale, no século XVIII, ao prelúdio que antecede as fugas ou outras composições do gênero. Por ser o início efetivo do discurso (musical), o exordium deve possuir um caráter convidativo, seja por ousar quebrar o silêncio que o antecede ou por silenciar o que, de outra maneira, obscureceria o início do discurso.

\subsubsection{2 - Narratio}

Na narratio temos a clara definição do tema ou assunto principal, demonstrando a intenção do orador ou a natureza de uma composição musical. Equivale à entrada da voz numa ária, ou à primeira frase do instrumento solista num concerto.

\subsubsection{3 - Propositio}

A propositio tinha vez na oratória logo após a narratio, pois era comum que após a narração de fatos se propusesse um juízo acerca destes fatos (discursos dos gêneros deliberativo e judiciário). Em música tal divisão não se faz necessária. Assim sendo, por vezes o termo propositio acaba abarcando também as funções da narratio (nas fugas, por exemplo, é costume designar-se propositio à seção inicial na qual o número de partes da composição é revelado pela entrada sucessiva das vozes). 
Quando ambas existem, entretanto, a narratio toma o aspecto de uma construção por etapas da idéia central, enquanto a propositio é a enunciação direta desta idéia. Assim entendida, a propositio é o núcleo do discurso retórico, mais fundamental do que a narratio.

\subsubsection{4 - Confutatio}

Na confutatio ou refutatio têm lugar os argumentos que se opõem ao tema principal, num enfrentamento que gera tensão e instabilidade. Na música equivale aos momentos modulatórios e às visitas a outras regiões tonais, normalmente acompanhadas por variações do material temático. É o momento preferencial para a utilização dos cromatismos e das passagens contrastantes (presentes, por exemplo, nas fugas). $\mathrm{O}$ melhor exemplo, entretanto (e que escapa aos domínios da música do século XVIII, corroborando a tese por nós apresentada neste estudo), nos parecem ser os desenvolvimentos presentes na forma sonata.

Na oratória, a exposição, já pelo próprio orador, das idéias e objeções que pudessem ser utilizadas por seus opositores para combater seus pontos de vista consistia em rebuscada técnica, admirada e valorizada, por permitir ao ouvinte perceber a amplitude e profundidade com que o orador discernia o assunto que ora expunha. Além disso, contribuía para a avaliação ética do orador na medida em que este, ao não silenciar sobre contradições que se opusessem a sua argumentação, expunha a honestidade e lisura de seus propósitos, bem como a altivez e a honra de seu caráter.

\subsubsection{5 - Confirmatio}

Como o próprio nome indica, temos aqui a confirmação das idéias principais, sendo superadas as objeções apresentadas na confutatio. Em música, é caracterizada pelo retorno à estabilidade da tonalidade principal, pelo apaziguamento dos materiais temáticos propostos, ao mesmo tempo em que, por reiterar, sugere uma reexposição do que fora enunciado na narratio (ou propositio). 


\subsubsection{6 - Conclusio}

A conclusio (ou peroratio) é a conclusão do discurso ou da composição musical. Em música pode significar uma cadência final cuidadosamente preparada ou ainda conter uma repetição literal ou ligeiramente modificada do exordium. Nas fugas, corresponde ao pedal sobre a dominante ou tônica que anuncia o término das imitações, podendo ser toda a coda final de composições outras.

\subsection{3 - Elocutio}

Aqui se ajustam, na partitura, as partes previamente esboçadas. Podem ser acrescidas ornamentações, junções entre partes e alterações de estilo. Em música, o término da escrita iniciada na dispositio se dá na elocutio (ou decoratio, como às vezes é citada). Na oratória, os argumentos inventariados e organizados nas partes precedentes serão aqui traduzidos em palavras. Para que o discurso, organizado na dispositio, pudesse ser persuasivo, fazia-se necessário reforçá-lo através de figuras, as figuras retóricas. A elocutio ou decoratio é o momento privilegiado para fazê-lo.

\subsubsection{1 - Figuras retóricas}

Por meio das figuras, que são meios de reforço e ornamentação do discurso, se obtém uma comunicação mais eficaz com o ouvinte:

Figura é um recurso de estilo que permite uma expressão livre e ao mesmo tempo codificada, que se afasta do uso comum das palavras para obter mais força e adequação. É livre porque não somos obrigados a recorrer a ela para nos comunicar; e é codificado porque cada figura constitui uma estrutura conhecida, repetível e transmissível. Elas devem ser utilizadas como recursos de expressão e ornamentação. (BARROS, 2006, p. 15)

A sistematização das figuras retórico-musicais buscava relacionar à terminologia retórica seus correspondentes procedimentos ou “dispositivos” musicais, tornando-os inclusive acessíveis à utilização segundo a finalidade desejada para uma composição. 
Através da utilização destas figuras, poderia chegar-se mais facilmente à correta expressão do afeto musical desejado (affectio musica).

Estas figuras, quase sempre classificadas em principais (ou fundamentais) e secundárias (ou superficiais), poderiam ser desenhos melódicos, saltos melódicos específicos (que conteriam qualidades expressivas determinadas) e inclusive maneiras de utilização da dissonância (compendiadas no estudo do contraponto), tais como a nota de passagem (transitus ou commissura) e a preparação-suspensão-resolução (ligatura ou syncopatio). Determinados acordes, como o de quinta e sétima diminutas, eram especialmente pertinentes para momentos em que o acúmulo da tensão (psicológica) deveria ser expresso. Também procedimentos imitativos, tais como os cânones, fugatos e fugas possuíam características próprias, sendo mais adequados para atingir determinados objetivos. Isto evitava confusões e ambigüidades, garantindo que o ouvinte fosse levado sem erros ao afeto desejado pelo compositor. A própria escolha das tonalidades (realizada na inventio) deveria adequar-se à finalidade pretendida, e há descrições (por vezes contraditórias) dos sentimentos por elas evocados. ${ }^{17}$

\subsection{4 - Memoria}

A memorização do discurso pelo orador, a memoria, permitia ao orador que este se apresentasse com mais desenvoltura. Também a credibilidade do orador crescia consideravelmente, pois do orador que houvesse corretamente memorizado seus argumentos e a ordem em que seriam dispostos emanava uma autoridade afim à persuasão pretendida. Para a efetiva memorização do discurso era comum dividi-lo em partes menores (aproximadas às divisões da dispositio).

No processo composicional (musical), a memoria não é considerada importante, embora o seja do ponto de vista do intérprete.

\subsection{5 - Pronunciatio}

Igualmente a pronunciatio não nos será de grande valia, pois inclui as regras da correta dicção, a devida entonação, o repertório gestual e mesmo a disposição geral do

\footnotetext{
${ }^{17}$ Uma pormenorizada descrição das figuras encontradas em todos os tratados mencionados e de suas correspondências musicais pode ser obtida no meticuloso Musica Poetica de Dietrich Bartel.
} 
orador, o que se relaciona mais à interpretação musical propriamente dita do que ao processo composicional e analítico, nossos focos principais.

\section{5 - Forma Musical e Retórica}

Conforme nos relembra Mark Evan Bonds em Wordless Rhetoric, as definições comumente encontradas para o termo "forma", amplamente utilizado na estética, sempre sugerem um estranho paradoxo: duas acepções diferentes e mesmo contraditórias podem aplicar-se a um mesmo termo e parecerem, ambas, claramente apropriadas. O termo em questão possui significados ambíguos e opostos, sendo tomado ora como uma estrutura geral, cujas características abarcam grande número de obras, ora como a estrutura particular de uma única peça. No primeiro caso a forma refere-se às características comuns que obras diversas apresentam, no segundo aplica-se aos elementos que determinam a própria individualidade da obra referida.

Tal paradoxo reforça a suspeita de que o conceito de forma, por sua complexidade, mereça uma abordagem ampla e generosa, evitando simplificações que, uma vez incorporadas, podem reduzir significativamente a qualidade da abordagem do material sonoro.

\subsection{1 - Um conceito paradoxal}

Este “paradoxo semântico”, segundo Bonds, é um vestígio lingüístico de uma unidade conceitual ancestral, que teve seus laços rompidos em fins do século XVIII e início do XIX. Bonds cunha os termos “conformational” e "generative” para distinguir, respectivamente, as duas abordagens acima nomeadas. Tomaremos a liberdade de traduzi-los por abordagens “conformacional” e "generativa”:

O conceito de forma musical engloba duas perspectivas básicas que diferem radicalmente uma da outra. Por uma via, “forma” é sempre usada para denotar aqueles vários elementos estruturais que um grande número de obras têm em comum. Em termos de análise prática, esta abordagem para forma busca os menores denominadores comuns e observa as obras individuais em comparação com padrões estereotipados tais como a forma sonata, o rondó, ABA, e outros. Por questões de 
conveniência, esta abordagem de forma será chamada “conformacional”, por estar apoiada na comparação de uma obra específica contra uma tipologia abstrata, ideal.

A perspectiva contrária vê forma como a estrutura única de obra específica. Tal visão, diferentemente da primeira, é essencialmente generativa, à medida que considera a maneira pela qual uma obra individual cresce a partir de seu âmago e como os vários elementos de uma obra coordenam-se para constituírem um todo coerente. Em suas manifestações mais extremas, a idéia generativa de forma não faz distinção essencial entre a forma e o conteúdo de uma obra dada. ${ }^{18}$ (BONDS, 1991, p. 13-14)

No primeiro caso, a abordagem conformativa, tende-se a considerar forma e conteúdo como distintos, uma vez que a forma aplica-se a conteúdos diversos; no segundo, o princípio generativo, forma e conteúdo estão indissoluvelmente ligados, estando o conteúdo disposto de maneira específica nessa obra em particular.

Historicamente, é freqüente considerar-se que a visão generativa, preponderantemente presente durante os séculos XVII e XVIII, foi sendo paulatinamente substituída pela conformacional, no século XIX e início do XX. Essa substituição, presente na abordagem analítica, acaba por pressupor similar substituição no processo composicional. Não seria supérfluo notar que a cronologia desta transformação encontra equivalência junto ao desenvolvimento e vigência do processo retórico de composição (séculos XVII e XVIII), bem como ao seu alegado declínio durante o século XIX.

Tal substituição ou rompimento se deu a partir do momento em que o pensamento musical incluiu e desenvolveu em seu seio novas idéias. A mais importante delas é a emergência de um conceito abstrato para forma. Logo segue-se-lhe um crescente detalhamento das descrições das convenções estruturais que tiveram uso mais

\footnotetext{
18 "The concept of musical form encompasses two basic perspectives that differ radically form each other. On the one hand, "form" is often used to denote those various structural elements that a large number of works share in common. In terms of practical analysis, this approach to form looks for lowest common denominators and views individual works in comparison with such stereotypical patterns as sonata form, rondo, ABA, and the like. For the sake of convenience, this view of form may be called 'conformational', as it is based on the comparison of a specific work against an abstract, ideal type. The contrasting perspective sees form as the unique shape of a specific work. This view, unlike the first, is essentially generative, in that it considers each individual work grows form within and how the various elements of a work coordinate to make a coherent whole. In its most extreme manifestations, the generative idea of form makes no essential distinction between the form and content of a given work."
} 
acentuado, tendendo tais descrições a construir uma imagem prototípica de tais estruturas, e que inserem-se perfeitamente na emergente conceituação abstrata de forma.

Faz-se importante sabermos que, durante o século XVIII, a análise premiava aspectos melódicos, rítmicos e harmônicos, buscando relacioná-los em termos de variedade, unidade e coerência. Não havia, portanto, a prática de encaixá-los numa forma (aqui no sentido de "fôrma”) específica, pré-existente, e quando tal fato se dava não era considerado como a parte principal de uma análise.

Em contrapartida, já no início do século XIX, tem lugar a construção e aceitação de um conceito abstrato de forma. A construção de tal conceito fundamenta-se na busca de elementos estruturais comuns a diversas obras de tal maneira que, da verificação da presença destes em suficiente número de trabalhos, aceita-se a existência de um padrão, estereotipado, e enuncia-se que tais padrões são delimitadores e formadores do conceito (abstrato) subjacente à forma em questão. Para fins de análise, tal abordagem da forma tem como conseqüência a tendência generalizada à alocação dos materiais musicais num molde que lhes pareça o mais conveniente, segundo os padrões pré-definidos das formas disponíveis.

A alocação dos materiais musicais, assim realizada, favorece seu isolamento do todo, ainda que produza eventuais classificações acertadas. O que define a forma, aqui, é a presença do material, não sua relação com os outros materiais. Assim, estanques, eles parecem não adequar-se ao pensamento naturalmente fluido e conseqüente que a audição das mesmas obras provoca, o que indica uma ruptura provável entre o processo analítico e o composicional. Ao isolar os materiais, facilmente pode-se perder o que de mais essencial há no discurso musical: as suas conexões. Quiçá signifique desprezar a essência mesma das formas, em última análise.

Pelo lado oposto, uma perspectiva que veja forma como uma conformação única dos materiais num dado trabalho favorece a compreensão de como os vários elementos estão unidos e organizados coerentemente. Observando as conexões entre os elementos, realçando sua fluência à maneira de um discurso cuidadosamente elaborado, essa perspectiva tende a suprimir as diferenças entre forma e conteúdo.

A percepção do provável hiato entre o processo analítico e o composicional abriu caminho para o questionamento acerca do real abandono dos pressupostos composicionais retóricos pelos principais compositores do classicismo, Haydn, Mozart e Beethoven (este último, divisor de águas, por sua obra, entre o classicismo e o 
romantismo). Este questionamento manifestou-se razão embrionária para a retomada dos estudos sobre retórica musical, já em meados do século XX.

Eis o paradoxo semântico observado por Bonds: o termo forma pode significar um padrão definido ou um processo criativo, pode ser um molde estereotipado ou um arranjo ímpar de elementos de um trabalho único.

Ambas as acepções do termo possuem sua relevância e abrangência. Sem o conceito abstrato, que supostamente é inerente a uma determinada forma, não há como detectar os desvios (artísticos) de um plano original, nem como avaliar o parentesco entre construções similares entre si, que possam ser abrigadas sob a mesma terminologia (e tais classificações têm sua validade pela visão sistêmica que proporcionam). Por outra via, sem a visão do processo criativo não há como explicar os desvios operados, sob prisma artístico, e prolifera a tendência de simplesmente citar (ou exaltar, sob o signo da genialidade) os pontos nos quais as obras analisadas simplesmente não se assentam sobre os pilares conceituais. Perde-se a oportunidade (valiosa) de compreender que o conteúdo, por sua consistência e perfil únicos, felizmente ganha a prerrogativa de "deformar a forma" (aqui um molde que o aprisiona), esticando-a para os limites que a criação determina, mas sempre sob a égide de uma necessidade.

Modernamente, com a revalorização dos estudos sobre retórica musical, especialmente a partir de meados do século XX, há uma tendência à sobreposição das duas posições, por uma gradual alteração no conceito abstrato que define a forma através da aceitação da influência dos conteúdos. Conforme descrito por Bonds, exemplo notório desta tendência encontramos em Charles Rosen que, em seu conhecido estudo “Sonata Forms” está, já pela utilização do plural no título, revelando a premente necessidade de flexibilização do protótipo. (BONDS, 1991, p. 15)

Ambas as abordagens, se utilizadas convenientemente e em conjunto, podem construir uma análise musical potencialmente mais completa (porque mais abrangente), por articular dois pontos de vista opostos, a saber, do centro da obra para a sua periferia, e da sua periferia novamente em direção ao seu centro. A riqueza de tal método reside na validade da assertiva de que quanto maior for a visão em profundidade, menor ela será, naquele mesmo instante, em amplitude, e vice-versa.

Não é caso, portanto, de alinhar-se ferrenhamente a uma determinada corrente (ainda que as pontuais contendas a isto nos obriguem, pela busca do equilíbrio de forças 
que tencionamos promover), mas de conjugá-las, inclusive para transpor, por aceitação, o supracitado paradoxo a respeito do termo "forma".

\subsection{2 - Sonata como forma e como procedimento}

Diante desta nova perspectiva, poderíamos aceitar que forma sonata não é estrutura pré-moldada, inflexível (embora seja um padrão básico recorrente, não podemos nem queremos negá-lo), mas aproxima-se de uma escritura generativa, à maneira de um procedimento, no qual a coerência e a fluência das idéias são talhadas sob a lembrança do molde. A recorrência de um padrão, estereotipado, é produto da atuação de forças internas, dos conteúdos. O compositor, "inventor" do material, sabe dar aos materiais os contornos que eles mesmos parecem exigir. Reconhecer o que podem os materiais dar de si para a expressão desejada é reconhecer o que neles é persuasivo. E isto é, como já estudamos, procedimento retórico.

Esta escritura generativa, "à maneira de um procedimento", remete-nos a uma possível relação entre a forma sonata e a fuga. Se a aplicação inflexível dos esquemas formais à análise não produz os resultados esperados, isto é, não ilumina necessariamente os pontos-chave, é porque tal não deve ter sido o pressuposto do compositor. Bonds assim expôs essa idéia, citando "O Estilo Clássico”, de Charles Rosen:

A forma sonata, na visão de [Charles] Rosen, "não é uma forma definida, como um minueto, uma ária da capo, ou uma abertura francesa: ela é, como uma fuga, uma maneira de escrever, um senso de proporção, direção, e uma textura mais do que um padrão.” A perspectiva essencialmente generativa de Rosen para com a forma o leva a concluir que a forma sonata é, de fato, "uma imensa melodia, uma clássica frase expandida.” ${ }^{19}$ (BONDS, 1991, p. 15)

A metáfora adequada para esta perspectiva generativa sobre a forma sonata (e potencialmente aplicável a diversas outras formas) é a de música como um organismo, que cresce a partir de suas próprias entranhas, guiado por suas próprias necessidades.

\footnotetext{
19 “Sonata form, in Rosen's view, 'is not a definite form like a minuet, a da capo aria, or a French overture: it is, like the fugue, a way of writing, a feeling for proportion, direction, and texture rather than a pattern'. Rosen's essentially generative outlook toward form leads him to conclude that sonata form is in fact 'an immense melody, an expanded classical phrase'."
} 
Registremos o parentesco desta metáfora ao conceito de Schoenberg para forma, exposto em nosso segundo capítulo, segundo o qual os elementos devem funcionar de maneira orgânica, a coerência e a lógica concorrendo para que a compreensibilidade seja possível, a interconexão de idéias apoiada nas relações intrínsecas dos materiais. Percebamos quão intrinsecamente retórica é tal abordagem e quanto uma perspectiva claramente generativa permeia tal conceituação.

A posição aparentemente ambígua de Schoenberg, enquanto compositor e teórico, nos é reveladora. Concomitantemente à escrita de sua obra fundamental sobre a tonalidade, “Harmonia” (1911), ele reestruturava, em suas especulações composicionais, toda a linguagem por critérios que foram chamados atonais. De que maneira um renovador da linguagem musical que, via dodecafonismo, é historicamente tido como o agente do rompimento com a tradição tonal, pode simultaneamente compendiar esta mesma tradição? Como pode prestar reverência a algo com que pretende romper? Tal contradição parece-nos apenas aparente, pois quando derivamos ou inovamos a partir do conhecimento da tradição já construída sobre firmes pilares, o rompimento operado, ainda que se apresente abrupto ao senso comum, sempre é conseqüência natural da tradição herdada, como passo histórico elementar. Por esta via, a verdadeira e conseqüente revolução se dá pelos profundos conhecedores da tradição, os que sabem o que nela precisa e pode ser renovado, porque comungam sua essência; não pelos “reformadores de plantão", que mesmo quando julgam destruir estão, freqüentemente, apenas “construindo sobre” ou, o que é mais lamentável, reinventando o inventado.

Assim sendo, se toda ruptura é uma continuação às avessas, também o estabelecimento dos tipos formais e mais especificamente da forma sonata se dá por este prisma. É a ruptura de um processo generativo (portanto paulatina adesão à idéia conformacional) que avaliza o nascimento dos tipos formais. Há uma continuidade oculta sob as rupturas aparentes, embora o que se registre sejam as contradições. A relação entre a metáfora de música como organismo e as perspectivas conformacional e generativa foi, então, assim definida por Bonds:

Mas é importante reconhecer a distinção essencial entre a abordagem generativa e a conformacional para fins de análise. A primeira enfatiza o processo de crescimento 
virtualmente comum a todas as formas, enquanto a última enfatiza as diferenças estruturais gerais entre os vários resultados do crescimento. ${ }^{20}$ (BONDS, 1991, p. 28)

É preciso precavermo-nos, entretanto, contra os extremismos aos quais a abordagem generativa pode nos levar; toda perspectiva, por mais rica que se apresente, tem suas limitações. Nem o mais ordenado e cuidadoso desenvolvimento ou crescimento de um material pode resolver uma inadequação deste à finalidade proposta. Ou seja, um tema adequado a um minueto não será inadvertidamente tido como perfeitamente adequado também para uma forma sonata, desde que apenas diferentemente tratado em ambas as ocasiões. Não havemos, igualmente, de negar o surgimento histórico da forma sonata, seu florescimento e sua ampla utilização por praticamente todos os compositores em fins do século XVIII, todo o século XIX e até o início do século XX. É inegável a força que este protótipo possui, se atentarmos para o fato de que nele assentaram-se a maioria esmagadora dos primeiros movimentos (e às vezes também o último, embora menos freqüentemente o segundo) dos mais importantes gêneros musicais da tradição tonal, tais como as sinfonias, os concertos, os quartetos de cordas e as sonatas para piano ou para duos e trios.

O que a aceitação da influência dos processos retóricos na análise formal reclama é a devida atenção que se deva permitir aos conteúdos. Não é a exclusão do conceito abstrato de forma que está em jogo, mas como ele se construiu. Deseja-se corrigir uma eventual tendência analítica que sobrepõe o tipo formal ao material desmesuradamente, desprezando as características de seu conteúdo.

\subsection{3 - Plano harmônico e plano temático na forma sonata}

Uma das inadequações mais freqüentemente relatadas quando se sobrepõe ao repertório o molde da forma sonata é a dificuldade na delimitação dos temas principal e secundário. Em determinada fatia do repertório, notadamente naquele do período clássico, a delimitação dos temas não parece ajustar-se ao conceito abstrato de forma que supostamente seria verificado na obra. Fenômeno similar ocorre quando se tenciona encontrar, especialmente nas obras representativas do período romântico, o plano

\footnotetext{
20 "But it is important to recognize the essential distinction between the generative and conformational approaches to analysis. The former emphasizes the process of growth common to virtually all forms, while the latter emphasizes the broad structural differences among the various products of growth."
} 
harmônico previsto para a forma sonata nos manuais de formas musicais e análise. A observação destas inadequações é o ponto de partida, então, para que seja exercitada a flexibilidade do conceito abstrato concernente à forma em questão.

A forma sonata tem sido considerada de há muito como possuidora de, ao menos, duas características marcantes, ambas citadas em nosso capítulo segundo. Embora nossa abordagem schoenberguiana de forma tenha já nos precavido contra os excessos de uma afirmação excessivamente conformacional, aceitemos tal fato. A primeira característica marcante é a presença de dois temas, principal e secundário, mutuamente contrastantes, cuja delimitação seria extremamente fácil por apresentarem perfil melódico claramente definido e personalidade relevante. Seriam atributos do tema principal ser vigoroso, masculino, decidido. Já o segundo tema seria lírico, feminino, delicado. Em parte significativa do repertório tal pressuposto se realiza plenamente, mas o que fazer com a outra porção, ainda numerosa, e igualmente classificada como forma sonata? A segunda característica considerada inerente à forma sonata é a sua aderência a um plano harmônico pré-estabelecido. Novamente aqui nos vemos diante de obras que, invariavelmente tidas como formas sonata, simplesmente não cumprem o plano harmônico original. À constatação destas inadequações, as explicações geralmente alegam que é próprio do gênio do compositor quebrar regras, impondo sua vontade por sobre a tradição. Tal excentrismo é tolerado e mesmo admirado nos grandes artistas, como se fora a real marca de sua genialidade. Para responder a essas questões, aprendamos com Bonds que:

O que as muitas manifestações da forma sonata clássica dividem [entre si] é um contorno harmônico básico, que se move da tônica para uma tonalidade secundária próxima (normalmente a dominante se o movimento está em modo maior, ou a relativa maior se o movimento está em menor), e então para uma área de instabilidade harmônica , seguida por um retorno à tônica. Dentro desta construção, o número, o caráter e a disposição das idéias temáticas podem variar amplamente. ${ }^{21}$

(BONDS, 1991, p. 31)

\footnotetext{
21 "What the many manifestations of Classical sonata form do share is a basic harmonic outline, moving from the tonic to a closely related secondary key (usually the dominant if the movement is in major, or the relative major if the movement is in minor), then to an area of harmonic instability, followed by a return to the tonic. Within this construct, the number, character, and placement of thematic ideas can vary widely."
} 
Historicamente, parece haver na gênese da forma sonata, a priori, a definição de um plano harmônico, não de um plano temático. A segunda metade do século XVIII, momento desta gênese, enfatiza a realização deste plano harmônico. Apenas no século XIX é que cresceria a ênfase dada ao plano temático, e a recorrência dos temas principal e secundário passaria a sobrepujar então o cumprimento do plano harmônico original:

A disputa sobre se a forma sonata é uma construção harmônica ou temática ilustra os limites da definição [de forma]. A maioria dos estudiosos hoje concordaria que a resposta depende, em grande parte, se alguém está se referindo às teorias formais do século XVIII ou do século XIX. Por quase todo o século XIX e até o século XX, os escritores geralmente vislumbraram a forma sonata como uma construção temática. $^{22}$ (BONDS, 1991, p. 32)

E a justificativa para esta variação formal é, curiosamente, harmônica:

Como o idioma harmônico tornou-se crescentemente cromático no curso do século XIX, a tradicional polaridade entre dominante e tônica começou a perder seu papel central na estrutura dos movimentos em forma sonata: os compositores começaram a modular em direção às mais diferentes tonalidades, tanto na exposição quanto na recapitulação. Assim, o conceito novecentista de forma sonata colocou especial ênfase na presença de um contrastante "segundo tema" na exposição. ${ }^{23}$ (BONDS, 1991, p. 33)

\subsection{4 - Bipartição e tripartição na forma sonata}

A essa primeira diferenciação entre os planos harmônico e temático, uma outra vem juntar-se. A presença da barra de repetição ou ritornello ao final da exposição

\footnotetext{
22 "The dispute over whether sonata form is a harmonic or a thematic construct illustrates the limits of definition. Most scholars today would agree that the answer depends in large part upon whether one is referring to eighteenth- or nineteenth-century theories of the form. Throughout much of the nineteenth century and well into the twentieth, writers generally viewed sonata form as a thematic construct.”

23 "As the harmonic idiom became increasingly chromatic over the course of the nineteenth century, the traditional polarity of dominant and tonic began to lose its central role in the structure of sonata form movements: composers began to modulate toward more and different keys in both the exposition and the recapitulation. Thus the nineteenth century's concept of sonata form placed special emphasis on the presence of a contrasting 'second theme' in the exposition.”
} 
propõe, em primeira instância, uma visão bipartida da forma sonata, a saber: do início até o ritornello e do primeiro compasso após o ritornello até o fim do movimento. Entretanto, os tratados formais expõem uma divisão tripartida para a forma sonata: exposição, desenvolvimento (ou elaboração) e reexposição (ou recapitulação). Somemos a essa dicotomia o fato de que, durante o século XIX, vai ganhando corpo a tendência a suprimir-se a barra de repetição ao final da exposição.

Para compreender esta discrepância é necessário observar a alteração do conteúdo que se opera na forma sonata durante o século XIX. O supracitado alargamento das relações tonais, com o conseqüente encorajamento a modulações para regiões harmônicas mais distantes, conjugado a um plano temático mais elaborado (portanto com materiais mais afeitos a variações temáticas) acabam por dar ao desenvolvimento uma construção mais elaborada e extensa. Se no século XVIII o desenvolvimento e a reexposição juntos ofereciam proporção adequada à exposição (favorecendo uma visão bipartida), com o maior fôlego obtido pelo desenvolvimento no século XIX uma visão tripartida começa a impor-se. E quanto mais distantes tenham sido os vôos realizados no desenvolvimento, mais premente se torna uma longa reafirmação da tônica, estreitando as possibilidades de uma reexposição resumida.

A divisão tripartida tem sua origem, sob este panorama, no alargamento das partes da divisão bipartida, notadamente do desenvolvimento. O conceito abstrato que orienta a análise não pode, portanto, manter-se inerte, nem ignorar as alterações dos conteúdos historicamente evidenciadas, sob pena de tornar-se obsoleto.

Nossas conclusões sugerem que o século XVIII conheceu uma forma sonata organizada mais sobre um plano harmônico do que temático, no qual a região harmônica determina a função do material na estrutura mais do que seu perfil melódico (especialmente quanto ao tema secundário), e que se apresentava bipartida. Seu cunho geral pode ser dito racional, porque harmônico. Tal estrutura evoluiu paulatinamente para uma priorização melódico-temática durante o século XIX, com maior atenção dada ao caráter contrastante dos temas, alargamento das relações harmônicas e das proporções do desenvolvimento, que culminaram numa estrutura tripartida, cujo caráter geral é mais emotivo, porque melódico. A prioridade harmônica é mais indicada para superar outras discrepâncias que se apresentem, e assenta-se em sua precedência sobre os planos temáticos.

A proeminência dos contornos harmônicos não pode, entretanto, aplicar-se indiscriminadamente a formas outras, tais como o rondó simples ou o tema com 
variações, conforme notou Bonds: "A harmonia é de fato o menor denominador comum entre movimentos em forma sonata; mas disto não necessariamente segue-se que a harmonia, por isso, constitui a base para todas as formas”. ${ }^{24}$ (BONDS, 1991, p. 50-51)

\subsection{5 - Orientação pragmática e orientação expressiva}

Não é difícil notar que nos tratados sobre formas que conhecemos, como aqueles que estudamos no capítulo segundo, não é comum a utilização do termo retórica como fundamento para a construção dos chamados tipos formais. Vejamos, então, a citação de Heinrich Christoph Koch (1749-1816) em Musikalisches Lexikon, datado de 1802:

Retórica: este é o nome dado por alguns professores de música àquele corpo de conhecimentos pertencente à composição, por meio do qual seções melódicas individuais são unidas em um todo, de acordo com um propósito definido. Pela gramática, os conteúdos materiais de expressões artísticas são tornados corretos; a retórica, por outro lado, determina as regras pelas quais as expressões artísticas são concatenadas numa obra particular, de acordo com a finalidade a ser atingida. ${ }^{25}$ (KOCH apud BONDS, 1991, p. 53)

Percebamos que esse fragmento não se refere a composições vocais, mas sim instrumentais. As composições instrumentais, podemos deduzir, eram verdadeiras orações sem palavras, uma ordenada sucessão de “pensamentos musicais” (antes de serem planos temáticos ou harmônicos), tornados inteligíveis pela ação da retórica que, aplicada pelo compositor, garantia a coerente expressão desejada: "No interesse da inteligibilidade, essas idéias musicais - um amálgama de elementos melódicos,

\footnotetext{
24 "Harmony is in fact the lowest common denominator among sonata-form movements; but it does not necessarily follow that harmony therefore constitutes the basis for all forms."

25 "Rhetoric. This is the name given by some teachers of music to that body of knowledge belonging to composition by which individual melodic sections are united into a whole, according to a definitive purpose. Through grammar, the material contents of artistic expressions are made correct; rhetoric, by contrast, determines the rules by which the artistic expressions within a particular work are concatenated, according to the end to be achieved."
} 
harmônicos e rítmicos - tendiam a ser arranjadas dentro de um número limitado de padrões convencionais.” 26 (BONDS, 1991, p. 53)

Poderíamos reiterar citando George Barth que, em seu livro “The Pianist as Orator” (e o título não poderia nos ser mais revelador), assim se expressa:

Um professor de oratória do século XVIII normalmente começava por oferecer instruções em gramática como fundamento para o estudo da retórica. Mas Johann Mattheson, que instruía oradores musicais, queria antes de tudo mostrar que música e retórica eram profundamente relacionadas. ${ }^{27}$ (BARTH, 1992, p. 22)

A relação entre retórica e a organização dos pensamentos musicais adentrou 0 século XIX não apenas através dos tratados, mas também como informação dirigida aos ouvintes. A maneira de organizar as seções de uma obra (atual função da forma) era profundamente relacionada a uma eficaz apresentação das idéias dirigida a obter uma esperada resposta emocional da platéia. A retórica era sempre chamada a contribuir quando se tratava de questões tais como natureza e inter-relação dos períodos musicais, diversidade e unidade na obra, a qualidade expressiva das melodias, a reutilização ou transformação de uma convenção aceita, e demais passos inerentes ao processo composicional.

Orientação retórica inclui, desde sempre, valorizar a perspectiva do ouvinte a quem a obra se destina, perspectiva essa que deve, como não poderia deixar de ser, encontrar eco na análise, especialmente quando se trata de obras do século XVIII. Se a essa assertiva confrontarmos, entretanto, as já estudadas perspectivas conformacional e generativa, somos inequivocamente forçados a admitir que ambas têm como foco o próprio material musical, não o ouvinte. Portanto corremos o risco de, ao analisar obras do século XVIII, elidir uma fatia analítica que efetivamente integrava o processo composicional da época.

Essa inclinação em direção à audiência, característica da estética do século XVIII, é chamada por Bonds de “orientação pragmática”. Com a valorização da expressão individual no romantismo, as teorias da expressão individual foram, pouco a

\footnotetext{
26 "In the interests of intelligibility, these musical ideas - an amalgam of melodic, harmonic and rhythmic elements - tended to be arranged within a limited number of conventional patterns.”

27 "An eighteenth-century teacher of oratory usually began by offering instruction in grammar as a foundation for the study of rhetoric. But Johann Mattheson, who taught musical orators, wanted first of all to show that music and rhetoric were deeply related."
} 
pouco, alterando o cenário estético durante o século XIX. À orientação pragmática opôs-se então a "orientação expressiva”, na qual o papel destinado à audiência foi drasticamente reduzido. Na esteira desta transformação, outras vieram:

Essa mudança manifestou-se de numerosas maneiras. O expressivo crescimento da crítica e da análise musical no princípio do século XIX ocorreu, em grande parte, como resposta ao crescente desejo das audiências de entender um repertório sempre mais exigente. ${ }^{28}$ (BONDS, 1991, p. 56)

A revalorização da retórica, modernamente ocorrida, também aí encontra reforço, dada a conhecida inapetência de grande parte do público da segunda metade do século XX para com a música de seu próprio tempo. Este fato, a princípio ignorado ou desprezado, acabou por tornar-se uma preocupação recorrente de vários setores da produção musical.

A mudança gradual da orientação pragmática para a expressiva inseria-se na simultânea mudança da posição do artista na sociedade. De artesãos a serviço de uma corte ou igreja, compositores foram alçados à condição de admirados gênios:

O status social do compositor também se alterou fundamentalmente entre 1750 e 1850. Por quase todo o século XVIII, o compositor foi geralmente visto como um artesão; mas pela metade do século XIX os mais destacados compositores foram percebidos (e em alguns casos idolatrados) como artistas independentes. ${ }^{29}$ (BONDS, 1991, p. 56)

É pertinente notarmos que a orientação expressiva, na qual é privilegiada a individualidade do compositor e de sua obra, acrescida da perspectiva romântica que idealiza o próprio compositor, são subjacentes à historiografia e à análise musical que herdamos e sob a qual construímos a maior parte de nosso vocabulário formal. Esta pode ser uma das razões para a supracitada inadequação de premissas formais em

\footnotetext{
28 "This change manifests itself in a number of ways. The enormous growth of musical criticism and analysis in the early nineteenth century occurred in large part as a response to the growing desire of audiences to understand an ever more demanding repertoire.”

29 "The social status of the composer also changed fundamentally between 1750 and 1850 . Throughout most of the eighteenth century, the composer was generally seen as a craftsman; but by the middle of the nineteenth, the most esteemed composers were perceived (and on occasion idolized) as independent artists."
} 
relação a um segmento do repertório. Novamente, estamos diante de um aspecto que pode ser reavaliado com a retomada de preceitos retóricos. Registremos ainda que, em detrimento do papel da audiência, a sobreposição da orientação expressiva à pragmática retirou significativa responsabilidade do compositor para com a inteligibilidade de sua própria obra. Tal situação contribuiu para o lento declínio de uma alegada função social da música durante o século XIX, com a aceitação da independência do artista fomentando seu crescente isolamento.

\subsection{6 - Música instrumental: oração sem palavras}

A metáfora de música como linguagem, aplicada à música instrumental, uma “oração sem palavras”, conseguiu impor-se durante a segunda metade do século XVIII. A predominância da música vocal na Renascença (séculos XV e XVI) foi seguida pelo equilíbrio entre música vocal e instrumental no Barroco (século XVII e primeira metade do XVIII). Apenas no Classicismo (segunda metade do século XVIII e primeira década do XIX) a música instrumental superou, em importância, a produção vocal, conquistando sua autonomia. Aplicar a referida metáfora à música puramente instrumental significou o maior desafio a que os preceitos retóricos haviam já sido expostos, mas possibilitou-lhes exibir e ampliar suas mais ricas potencialidades. Tais potencialidades puderam semear ocultos pressupostos retóricos durante todo o século XIX e mesmo ousaram ressurgir em meados do século XX.

No que tange à música instrumental, a principal questão que se apresenta é se pode a música, sem a ajuda das palavras, expressar um significado particular, discernível, explícito, extramusical. A amplitude e envergadura desta questão nos obrigam a confessar que, mesmo após a exposição de nossos argumentos, a fenda aberta por esta exposição será passível de réplicas igualmente fundamentadas, que assentem o contrário do que vamos afirmar. Num mundo marcado pelos enfrentamentos, no qual as posições conciliatórias são as mais elegantes e valiosas ferramentas para equilibrar a violência onipresente das contradições, é ato de quase irresponsável coragem expor-se e demarcar posição sobre temas polêmicos. Entretanto, é nossa obrigação ética e acadêmica expormo-nos em defesa daquilo em que realmente vislumbramos a verdade. E ainda assim, poderemos estar apenas equivocados. 


\subsubsection{1 - Mimese: música como imitação}

A noção de que a música instrumental pode expressar algo parte do pressuposto de que ela é, em essência, imitação da música vocal. ${ }^{30}$ Mattheson assim se manifestou sobre esta relação: “A primeira distinção entre música vocal e música instrumental é que a primeira é a mãe, a segunda é a filha (...)” ${ }^{31}$ (MATTHESON apud RATNER, 1980, p. 4). Os concertos solo seriam aparentados às árias, sinfonias são grandes corais. (KOCH apud BONDS, 1991, p. 63) Os compositores parecem não ter se oposto a essa idéia, pois:

Funcionalmente, uma grande quantidade da música instrumental que perpassou os séculos XVII e XVIII serviu, de fato, como uma substituição para a música vocal. Um amplo repertório de diversos gêneros, incluindo ricercar, canzona, sonata da chiesa e concerto grosso, desenvolveram-se em parte como substitutos ou suplementos instrumentais para elementos da liturgia, especialmente na Missa e nas Vésperas. ${ }^{32}$ (BONDS, 1991, p. 64)

Mas a música vocal, por sua vez, é imitação do quê? O conceito grego de mimese (imitação) estabelece que todas as artes são, em essência, imitações da natureza, em variados níveis. Na pintura e na escultura tal processo imitativo é imediato, constituindo-se, inclusive, como critério qualitativo para o julgamento e valoração da obra analisada. O processo (mimético) de aproximar-se o máximo possível do real objeto retratado dominou longamente a estética pictórica (naturalismo), comportando-se como um paradigma tão forte quanto o sistema tonal o é para a música ocidental. O teatro imita a própria vida, acontecida ou “acontecível”, mesmo estilizada no drama e na comédia. A dança imita o gesto humano e os gestos do mundo, embora seja mais

\footnotetext{
${ }^{30}$ Notemos que determinada qualidade expressiva que uma frase na música instrumental deva possuir é freqüentemente solicitada pela adição do termo cantabile na partitura.

31 "The first distinction between vocal music and instrumental music (...) is that the first is the mother, the second the daughter (...)”.

32 "Functionally, a good deal of instrumental music throughout the seventeenth and eighteenth centuries did in fact serve as a replacement for vocal music. A large repertoire of diverse genres, including the ricercar, canzona, sonata da chiesa, and concerto grosso, had developed in part as instrumental substitutions or supplements for elements of the liturgy, especially in Mass and Vespers.”
} 
abstrata do que as artes plásticas. Na música, considerada a mais abstrata de todas as artes, tal imitação não se dá tão diretamente. E na raiz dessa mais abstrata imitação operada pela música reside a predileção platônica pela música e sua utilização como instrumento pedagógico, bem como seu cuidado em limitar seu poder quando não desejado, como em A República. ${ }^{33}$

A construção do discurso musical não se dá como uma seqüência de sons que imitem os sons emitidos pela natureza. Nossas composições não são sons de passos sobre folhas secas, depois sons de uma corrida em campo aberto, seguidos dos sons de um banho na cachoeira. Nossas composições são ritmos, recortes de variados tamanhos e medidas que inscrevemos no tempo, conjugados a melodias, que são proposições baseadas no som (este um dado natural), mas organizados seqüencialmente sobre um fundo cultural: escalas, modos, tonalidades, sistemas. Nossas composições são proposições sintáticas.

Eventualmente, determinados efeitos podem ser obtidos nos instrumentos musicais e imediatamente reconhecidos (como os batimentos cardíacos, por exemplo), ou ainda possamos dizer que a música programática, com a inestimável ajuda das palavras, notemos, queira nos guiar a audição, determinando o que está sendo representado. Mesmo uma "música descritiva” utiliza as palavras de seu título e do subtítulo de seus movimentos para transpor o ouvinte ao universo retratado.

No mínimo duas questões fundamentais aqui seriam cabíveis. Primeira: na falta absoluta de tais palavras, todos os ouvintes chegariam às mesmas impressões e, à audição das mesmas obras diriam todos, inequivocamente, estarem diante das quatro estações do ano, ou ainda, diante de um rio, mais especificamente, do rio Moldávia? ${ }^{34}$ E a nossa resposta aqui é não. Mesmo que o movimento do rio possa estar sugerido no fluxo contínuo das melodias, tais melodias não apontam univocamente para o significado extramusical “rio”, e muito menos para o "Moldávia”. Se Vivaldi houvesse colocado, jocosamente, o título "Meus quatro amores” (o que seria um escândalo vindo de um padre!), o que buscaríamos ouvir? Vivaldi e seu par num piquenique à sombra das árvores?

\footnotetext{
${ }^{33}$ No livro III de “A República”, Platão elimina de seu Estado ideal vários modos ou harmonias por considerá-los falhos na construção do caráter dos jovens, embora aceite a permanência das "harmonias frígias e dóricas"; o mesmo se dá quanto aos ritmos e instrumentos.

${ }^{34}$ Referência a “As Quatro Estações”, de A. Vivaldi; e ao “Moldávia”, de B. Smetana.
} 
Nossa segunda questão é: a audição de uma música puramente instrumental, cujo título fosse “Sonata para piano, opus 2, n 1 , em fá menor” ${ }^{35}$, poderia levar todos os ouvintes a reportarem-se a um mesmo objeto ou fato, extramusical, univocamente? E nossa resposta seria, novamente, não. A mimese operada pela música pode se dar, entretanto, num nível significativamente mais elaborado.

A série harmônica, fenômeno natural, prescreve como primeiro harmônico a diferir da própria fundamental uma quinta justa. Portanto, pode-se aceitar que, num nível físico, todo som existente gera uma quinta justa ascendente e que, num nível metafísico, toda fundamental atual foi gerada como quinta de outra fundamental, ancestral. Similarmente, a construção de uma tríade maior pode ser justificada como oriunda dos primeiros harmônicos da série (suas proporções mais simples), ao passo que a inversão destes mesmos primeiros harmônicos em sentido descendente gera a tríade menor. Da mesma maneira, poderíamos espelhar as escalas modais, e descobrir que o modo jônio e o modo frígio são inversões um do outro (assim como o lócrio e o lídio, e o eóleo e o mixolídio também o são), enquanto o espelho no qual eles se "miram" seria o modo dórico (pois que sua inversão gera a si próprio). ${ }^{36}$ Não estamos aqui anunciando o sistema modal ou tonal como "naturais", mas apenas expondo o que, em suas acomodações culturais, é efetivamente natural, enquanto fenômeno físico. O mesmo pensamento espelhado manifesta-se na música atonal dodecafônica, pelos retrógrados, as inversões e os retrógrados de inversões; bem como a construção mesma da série dodecafônica pode ser tida como natural, uma vez que todos os sons acabam por aparecer mais cedo ou mais tarde na série harmônica. Até mesmo uma divisão em quartos de tom pode ser dita "natural”.

A questão é que, se o dado natural é o próprio som, então ele imita-se a si próprio à razão de quinta, como primeiro recurso mimético disponível. Então, a uma melodia dada, o processo de reexpô-la quinta acima seria mimese, porque imitação da natureza (de si mesma). E temos diante de nós o princípio estrutural de uma fuga.

Se, entretanto, não imitamos a melodia, mas deixamos que a quinta justa da fundamental de sua tonalidade eleja-se como nova tonalidade fundamental enquanto primeira região harmônica aparentada, e sobre tal região construímos um segundo

\footnotetext{
${ }^{35}$ Referência à obra de Beethoven.

${ }^{36}$ Devo aos professores Orlando Mancini e Ricardo Rizek a verificação dos espelhamentos enunciados desde o início deste parágrafo, em aulas por eles ministradas.
} 
melodia, um segundo tema, também isto é mimese. E agora temos diante de nós o princípio estrutural da exposição de uma forma sonata.

Uma séria objeção a essas premissas poderia assim ser formulada: mas se o som imita-se a si mesmo, imita sua própria estrutura física, como pode tal processo converter-se em expressão de significados que promovem respostas emocionais? Ou ainda: se nossas composições são, em essência, proposições sintáticas, e o que ouvimos são transformações e elaborações desta matriz sintática, então o que a música exprime é, em última instância, a sua própria sintaxe? E isto é o que de mais anti-retórico poderíamos concluir: a música como uma linguagem auto-referencial, não dirigida ao ouvinte, e incapaz de apontar para qualquer significado extramusical. Enfrentemos tal objeção.

Se, à adoção da figura retórica syncopatio, que conhecemos por preparaçãosuspensão-resolução, e que estudamos detidamente na harmonia e na quarta espécie do contraponto, for feito o questionamento sobre a proveniência de tal desenho, nossas especulações poderiam desvelar procedimentos lógicos que, amiúde, passam despercebidos em nossa realidade pedagógica.

À pergunta: por que a resolução de uma dissonância se dá quase invariavelmente por grau conjunto descendente?, responderíamos que, do ponto de vista da linguagem, se trata de um momento de relaxamento que sucede à tensão precedente, e que a alternância entre tensão e relaxamento é o fundamento dos movimentos que garantem a sobrevivência dos seres em nosso planeta (a sístole e a diástole cardíacas, a inspiração e a expiração, o movimento pendular que os membros realizam alternadamente para vencer a força da gravidade, por exemplo).

Ao que caberia perguntar: o que garante essa hierarquia entre a tensão e o relaxamento na linguagem, visto ter sido utilizada uma metáfora orgânica? Ao que responderíamos: as mensuráveis relações intervalares em questão, as quais, por sua natureza numérica (de razões mais ou menos simples, ou mais ou menos complexas), manifestam o grau de maior ou menor proximidade (ou maior e menor distanciamento) entre dois sons; relações naturalmente dadas, pois que advindas da série harmônica, e que culturalmente acomodamos e classificamos em consonância e dissonância. Assim sendo, ao ser expresso o sistema de referência (a tonalidade), suas polarizações culturais remetem-se a seus princípios naturais (série harmônica), gerando uma hierarquia entre tensão e relaxamento que podem ser fisicamente percebidos, pois que a membrana do tímpano de nossos ouvidos não pode ser fisicamente insensível à série harmônica. 
Ainda assim conviria a insistência: mas por que o grau conjunto? Diríamos: porque os passos melódicos vizinhos preenchem e explicam o caminho (psicológico) que um salto deixa vazio, e que tal caráter de proximidade e simplicidade é afim ao relaxamento desejado. E, por último, à questão: mas por que descendente?, afirmaríamos que o relaxamento dos materiais no âmbito da física equivale ao descenso no nível das alturas (musicais). Relembraríamos que relaxar a pele de um tímpano ou as cordas de um violino (que estejam a ponto de se romperem, por exemplo) significa “descer suas alturas”.

A esta explicação lógico-matemática destes processos que são mormente tidos como procedimentos semânticos (e que tão rapidamente se impõem ao ouvido) procede a constatação da precedência conceitual da musica theorica sobre a musica practica, acenando com um acordo ao pitagorismo, ao platonismo, à ars musica medieval. Afirma-se, por extensão, a antecedência do quadrivium sobre o trivium. E por antecedência não pressupomos nem preponderância nem superioridade, mas apenas uma categoria de proveniência.

Entretanto, resta ainda buscar esclarecer por que meios uma rede de hierarquias, reveladas fisicamente e acomodadas num paradigma auto-referencial, sintaticamente organizado, pode comunicar-se diretamente ao campo expressivo, adquirindo contornos semânticos. Como pode uma estrutura sintática acessar diretamente o campo simbólico, atingindo toda a rede de emoções, como tal salto qualitativo se dá?

Contudo, os sons, fenômenos físicos sobre os quais todas essas construções da sintaxe se dão, são tornados plenos de significado pela espécie humana. É a memória da espécie quem nos legou tais significados, que transbordam em todos os cantos do planeta, fazendo com que a música seja recorrentemente cantada como idioma universal. E a música, arte humana, organiza a memória de tais significados e os atualiza diante de forças culturais polarizadoras, como a tonalidade.

Nascidos das interjeições que expressam alegria ou dor, dos gritos de horror diante do perigo e de desespero face à morte, das rumorosas comemorações e grunhidos que marcavam o sucesso de uma caçada, da entonação sensual do cortejo amoroso, nascidos daí e de inumeráveis outras experiências ancestrais da humanidade, intervalos, desenhos melódicos, glissandi, acentos, sforzandi, rallentandi adentraram o universo musical (à medida que o construíam), como lembrança psíquica primordial destes mesmos acontecimentos, desde tempos imemoriais. São estas estruturas, prenhes de 
significados, as constituintes primitivas de todo discurso musical, e a razão principal da resposta emocional que as melodias provocam.

A melodia, ao imitar as inflexões da voz, expressa lamentos, choros de dor ou de alegria, ameaças ou gemidos; todas as significações vocais das paixões estão dentro de seu domínio. Ela imita as inflexões de diferentes línguas, e a elevação e queda [de entonação] originadas em cada idioma por certos movimentos da alma. Ela faz não meramente imitar, ela fala; e sua linguagem - inarticulada mas vívida, ardente, apaixonada - tem mil vezes mais energia do que a fala mesma. ${ }^{37}$ (ROUSSEAU apud BONDS, 1991, p. 67)

A música instrumental, primariamente tida como inferior à vocal por não expressar-se também em palavras, não podendo, portanto, veicular idéias racionais, passa a ser considerada, no transcorrer do século XVIII, um instrumento privilegiado justamente por dirigir-se imediatamente aos estados da alma, sem a mediação de outras linguagens.

Somente na música instrumental pode o compositor ser um orador; na música vocal ele não pode nada mais fazer do que traduzir para a linguagem musical o discurso do poeta, e desta maneira não pode nem deve ser algo mais do que um tradutor, um imitador, um parafrasta. ${ }^{38}$ (CARPANI apud BONDS, 1991, p. 139)

O que nascera como limitação convertera-se em virtude. E mais: esta nova posição, a autonomia da música instrumental, advogaria a favor de um conceito retórico de forma.

\footnotetext{
37 "Melody, in imitating the inflections of the voice, express laments, cries of pain or joy, threats, or groans; all the vocal significations of the passions are within its domain. It imitates the inflections of different languages, and the rise and fall caused in each idiom by certain movements of the soul. It does not merely imitate, it speaks; and its language - inarticulate but vivid, ardent, passionate - has a hundred times more energy than speech itself."

38 "Only in instrumental music can the composer be an Orator; in vocal music, he can do no more than translate into musical language the discourse of the poet, and therefore he cannot and must not be anything other than a translator, an imitator, or a paraphrast.”
} 


\subsection{7 - Gramática musical e retórica: limites}

Harmonia, contraponto e formas musicais são estudos considerados essenciais a quem almeja a composição musical, e efetivamente o são. Juntos, constituem a gramática da música, suas regras, o material estrutural de que uma composição é feita. Esta gramática permite uma apreciação técnica do material musical, no qual juízos sobre a correção ou imperfeição na utilização do material são aceitos. Uma composição pode, nessa instância, ser considerada "tecnicamente boa", porque nela as regras gramaticais são utilizadas corretamente.

Mas a correção gramatical de uma composição musical não significa que seu conteúdo possua, de per si, qualidades expressivas. Com efeito, se, ao ouvirmos uma obra pela primeira vez, dissermos que ela nos pareceu "tecnicamente correta”, isto denotará antes a falta de uma virtude esperada do que a expressão de uma qualidade.

Contudo, se apenas a correção gramatical não é suficiente, faz-se então necessário que a obra seja considerada "retoricamente correta": ela deve ser persuasiva. A isso se deve o fato de que o estudo sistemático da harmonia, do contraponto e das formas musicais seja tido como requisito essencial à composição musical, mas não entendido como a composição musical propriamente dita. Falta a estes valorosos requisitos uma teia invisível que os una, de maneira a torná-los tão perfeitamente concatenados e articulados que se façam convincentes, porque tradutores de uma lógica intrínseca, que é a da linguagem musical.

A construção desta rede de conexões é tarefa da retórica. Articular as menores estruturas harmônicas e os artifícios contrapontísticos de maneira que, de seu lento acúmulo em unidades fraseológicas sempre crescentemente maiores, as periodicidades resultantes possam finalmente remeter-se a uma forma musical, é função retórica.

Não se trata, obviamente, de subestimar a gramática. Pelo contrário, num tempo em que o domínio técnico do arcabouço harmônico e contrapontístico esteja, porventura, decadente, a tarefa de recuperá-lo precede, pedagogicamente, qualquer outra. Daí a necessidade de, simultaneamente à revalorização da retórica, proceder-se a uma retomada artesanal do estudo da harmonia e especialmente do contraponto. Uma rede virtuosa de conexões não pode, decididamente, ser tecida sobre uma gramática claudicante. 
A gramática fornece fundamento para todas as artes retóricas: uma obra deve ser correta antes que possa ser eloqüente. Em termos lingüísticos, a gramática engloba a morfologia - a construção de palavras individuais - e a sintaxe, o arranjo destas palavras individuais dentro de unidades mais amplas de frase e sentença. A sintaxe, por sua vez, está intimamente ligada à prática da pontuação, pela qual as unidades individuais de pensamento são realçadas ou relacionadas a uma outra. A gramática musical, aos olhos dos teóricos do século XVIII, segue este mesmo padrão. Ela começa com simples notas ou acordes, os quais se unem para formar unidades de pequena escala, as quais por sua vez se combinam para formar unidades de tamanhos sempre crescentes. ${ }^{39}$ (BONDS, 1991, p. 71)

Desprezadas as diferenças terminológicas, os autores do século XVIII concordaram sobre as funções dos elementos musicais no discurso e suas correlações com a pontuação verbal. Cadências perfeitas (ou autênticas) servem à conclusão de grandes seções ou de movimentos inteiros, equivalendo ao ponto final; cadências à dominante estão ao fim de frases suspensivas, equivalendo aos dois pontos ou ao pontoe-vírgula; cadências de engano e outras pontuações aparentam-se às vírgulas, e assim por diante. Sem uma articulação inteligente dessas cadências, as frases e períodos ficam sem sentido, impondo-se no tempo enquanto proposições inconseqüentes que, ao final de seu discurso, não se realizam logicamente enquanto expectativas aguardadas e desejadas. É, pois, pelos pressupostos da retórica que os discursos se fazem persuasivos, pois ela orienta os elementos da linguagem na direção correta, segundo a finalidade que se busca atingir. Ao valorizar as conexões entre elementos a partir de uma idéia final, perseguindo obstinadamente a persuasão do ouvinte, a retórica acaba por determinar a hierarquia das idéias e de seus entrelaçamentos. E, na evolução da linguagem musical, cronologicamente observada, tais pressupostos retóricos precedem o nascimento dos tipos formais, permeando perspicazmente sua gênese. Claro está, portanto, que esta constatação ratifica a ascendência retórica das formas musicais.

\footnotetext{
39 "Grammar provides a foundation for all the rhetorical arts: a work must be correct before it can be eloquent. In linguistic terms, grammar encompasses both morphology - the construction of individual words - and syntax, the arrangement of these individual words into the larger units of phrase and sentence. Syntax, in turn, is closely allied to the practice of punctuation, by which individual units of thought are set off and related to one another. Musical grammar, in the eyes of eighteenth-century theorists, follows the same pattern. It begins with individual notes and chords, which join to form small-scale units, which in turn combine to form units of everincreasing size.”
} 
Do ponto de vista das alturas, quem oferece a estrutura hierárquica que determina as tensões e repousos (melódicos e harmônicos), gerando e reiterando expectativas em pequena escala, é um sistema referenciado (tonalidade). Mas a construção mesma da seqüência das frases e períodos, inteligentemente orientada para manipular as gradações de expectativa desejadas, em larga escala (mesmo que subsidiadas pela tonalidade), é função discursiva, não dada pela sistemática, é ato retórico.

\subsection{8 - Tema: essência e retórica da forma}

Além de toda a nomenclatura que música e retórica (via gramática) dividem (período, frase, metro, ritmo, cadência, tema), o próprio termo “composição” é derivado da retórica e aplicado à música. Relembremos que, dos cinco estágios apresentados no processo retórico, apenas os três primeiros (inventio, dispositio e elocutio) referem-se à composição musical propriamente dita, sendo os dois restantes (memoria e pronunciatio) mais afeitos à interpretação musical (pois se referem, originalmente, ao momento em que o discurso é efetivamente proferido, não à sua composição).

Historicamente, essas divisões do processo aparecem, com algumas alterações, em numerosos tratados sobre composição musical do século XVIII. Embora haja distinções entre eles, Bonds destaca o que possuem em comum:

Dois pontos sobressaem consistentemente [nos tratados do século XVIII]: (1) A forma deve ser compreensível se a inteligibilidade é pré-requisito para qualquer composição que busque penetrar a mente do ouvinte e mover seu espírito. (2) O processo de ordenar, elaborar e modelar as idéias de maneira efetiva pode ser ensinado - esta, inclusive, é uma das premissas básicas da disciplina retórica - mas o processo de criar essas idéias não o pode. ${ }^{40}$ (BONDS, 1991, p. 81)

Entretanto, Mattheson, o possivelmente mais importante e certamente o mais influente dos tratadistas do século XVIII a abordar tal questão, não compactuava com a

\footnotetext{
40 "Two points stand out consistently: (1) Form must be comprehensible if a intelligibility is a prerequisite for any composition that is to penetrate the mind and move the spirit of the listener. (2) The process of ordering, elaborating, and shaping ideas in an effective manner can be taught - this, indeed, is one of the basic premises of the discipline of rhetoric - but the process of creating these ideas cannot.”
} 
última parte dessa assertiva, a de que o processo de criar idéias não pode ser ensinado. O paralelo entre forma musical e as seis partes de que se compõe a dispositio (exordium, narratio, propositio, confutatio, confirmatio e conclusio), proposto por Mattheson em Der vollkommene Capellmeister (1739), opõe-se ao citado pressuposto, embora nem sempre tenha sido devidamente compreendido.

Não apenas o processo analítico-composicional de Mattheson, mas também seu método de ensinar composição é baseado nos preceitos retóricos, é deles derivado. Se o processo de composição baseava-se em três estágios (inventio, dispositio e elaboratio), também o método de ensinar composição consistia de três etapas: “uma apresentação de regras e preceitos, incluindo as convenções de periodicidade, seguida por uma descrição de gêneros, e concluída com exemplos específicos de obras existentes.” ${ }^{41}$ (BONDS, 1991, p. 82, 83)

Estas etapas eram derivadas dos manuais de retórica que circulavam no século XVIII, estes quase sempre apoiados na Institutio Oratoria, de Quintiliano que, como apresentado em nosso capítulo primeiro, tinha como fonte principal a Retórica, de Aristóteles.

Ao descrever a maneira como unidades menores juntam-se para formar unidades maiores, ou como sentenças unem-se para formar parágrafos (frases formando períodos, na terminologia por nós adotada no capítulo segundo), Mattheson admite que as unidades menores sejam constituídas dos materiais básicos (notas, acordes, ritmos), articulados pela pontuação oferecida pelas cadências. Mas quanto à construção das unidades maiores, ou seja, dos movimentos inteiros ou de grandes seções de movimentos, não bastaria o acúmulo crescente de parágrafos.

A construção de uma casa não se faz apenas pela sobreposição dos tijolos e cimento que originam paredes, e das paredes que formam os cômodos, e da livre junção dos cômodos entre si. Também se faz necessária uma prévia idéia da casa como um todo. E para forjar tal idéia previamente é necessário questionar-se acerca da finalidade a qual se destina a casa a ser construída. Mas como conceber essa idéia geral sem, eventualmente, retorcer cômodos e sacrificar paredes? ${ }^{42}$ Como não permitir que tipos formais imponham-se ao material musical, limitando-o; como garantir que o material

\footnotetext{
41 “(...) a presentation of rules and precepts, including the conventions of periodicity, followed by a description of genres, and concluding with specific examples of actual works."

${ }^{42}$ A analogia entre a composição de um discurso e a construção de uma casa está presente na Institutio Oratoria, de Quintiliano, conforme Bonds, 1991, p. 86.
} 
seja potencializado pela forma? Ou ainda, como obter uma profícua intersecção dos princípios conformacional e generativo?

A solução proposta por Mattheson passa pela aceitação de que é a finalidade pretendida que determina tal plano geral, que tal finalidade é a expressão de um páthos ou afeto específico, e que a comunicação deste afeto dá-se, fundamentalmente, pela enunciação de um tema:

Aqui, o ponto central, para Mattheson, não é tanto o próprio esquema de seis partes quanto a idéia de elaboração temática. Sua abordagem em relação à forma começa com o tema ou Hauptsatz - o sujeito da Klangrede [uma "oração em notas"] - e continua com sua subseqüente elaboração. ${ }^{43}$ (BONDS, 1991, p. 88)

Mais importante do que uma disposição esquemática é a idéia de um tema central sobre o qual as devidas elaborações são realizadas. A forma é, sob este prisma, essencialmente, temática. É o caráter do tema que determina suas possíveis elaborações, e essas elaborações "abrem caminho" por entre as partes do dispositio, cuja maleabilidade já consta, inclusive, como preceito da retórica. O conteúdo temático preenche a forma, soprando-a desde dentro, de maneira a moldá-la segundo suas necessidades (as do conteúdo). Do conteúdo parte-se em direção à forma. Entretanto, como há uma premeditada e providencial convergência entre o conteúdo utilizado e a forma pretendida, uma certa adequação formal nunca pressupõe a desfiguração completa do padrão, mas antes um enriquecimento eventual de suas premissas.

Nestes termos, a descrição dos gêneros apresenta-se como subsídio para a adequação formal na visão de Mattheson, enquanto a composição de um tema pode ser derivada da observação dos temas nos exemplos musicais observados. A reutilização de idéias pré-existentes não se erige como falta de originalidade, e da observação dos temas alheios e de sua aplicação segundo a expressão desejada podem derivar os temas do aprendiz. A invenção de um tema poderia comparar-se à pesca num lago, sendo que, de antemão, houvesse nos sido dada a oportunidade de lá colocar os peixes, ainda pequenos. Ou ainda: que um tema é uma possibilidade de conformação melódica, não tão individualmente qualificado, pois que retirado de um rio por onde as melodias

\footnotetext{
43 “Mattheson's central point here is not so much the six-part schema itself as the idea of thematic elaboration. His approach to form begins with the theme or Hauptsatz - the subject of the Klangrede - and proceeds with its subsequent elaboration.”
} 
continuamente fluem, e que está à disposição de todos, bastando aproximar-se de suas margens. ${ }^{44}$ E pedimos licença, agora, para uma re-citação (ou recitação?):

De fato, a abundância dos assuntos gera a abundância das palavras; e se existe nobreza nos próprios assuntos de que se fala, surge da natureza do assunto um certo esplendor natural das palavras (...) Assim, facilmente, na abundância dos assuntos, da própria natureza fluirão os ornamentos da oração, sem guia algum, desde que seja ela exercitada. (CÍCERO apud PLEBE, 1978, p. 68)

Mattheson e seus escritos são fundamentais como representantes do então recente pensamento formal, eles são referência histórica para a fase embrionária e a evolução dos tipos formais, e o fato de que tenham se apoiado indiscutivelmente na retórica confirma os pressupostos de nosso presente estudo. Ora, se os preceitos formais de Mattheson, fundamentos da organização do discurso musical do século XVIII (e disseminados durante o seguinte), ligam-se umbilicalmente aos preceitos retóricos de Quintiliano e Aristóteles, então forma musical e retórica estão não menos unidas, o que uma vez mais ratifica a ascendência retórica das formas musicais. E, diante de tal crucial constatação, não seria supérfluo saber que tanto Haydn quanto Beethoven possuíam cópias de Der vollkommene Capellmeister entre seus pertences.

\subsection{9 - Melodia e Hauptsatz}

O tema apóia-se, em larga medida, sobre o conceito de melodia. Mais do que em seu perfil rítmico, mais do que em sua harmonia inerente (confirmada ou não), mais do que nas intensidades ou timbres possíveis, é no parâmetro das alturas que reside o caráter principal do conceito de tema que o século XVIII nos legou. Assim concebida, a melodia é uma espécie de fluxo contínuo que perpassa as frases, períodos, e mesmo o movimento todo, incluindo o(s) tema(s). Diante de uma nova região harmônica, lá encontramos a melodia sublinhando tal novidade, à entrada de um novo timbre a melodia o permeia, conduzindo os crescendi, retendo andamentos, angulosa ou cromaticamente tratada nos pontos de tensão, reiterada e apaziguada nas recapitulações e nas codas finais, sempre a melodia, como guia principal, como fio condutor a

${ }^{44}$ Esta última imagem foi assim aproximadamente exposta em aula pelo professor Ricardo Rizek. 
esgueirar-se por todo o movimento, oferecendo ao ouvinte uma linha estrutural contínua. Consensualmente, a melodia atua como um dos principais apoios para o ouvinte, e é este caráter inteligível da melodia que a qualifica como elemento estrutural.

Que tal melodia esteja apoiada por todos os outros parâmetros musicais é fato dado, mas que o conceito de melodia do século XVIII seja tomado também como um poderoso guia estrutural nem sempre é evidente. Heinrich Christoph Koch, já na alvorada do século XIX, em seu Musikalisches Lexikon (1802), nos diz que:

(...) Disto segue-se que a melodia é um elemento essencial de qualquer obra musical, e que a harmonia, a despeito de sua grande importância e por mais que reforce os meios artísticos da expressividade, deve, contudo, ser [à melodia] subordinada. ${ }^{45}$ (KOCH apud BONDS, 1991, p. 91)

A concepção de que um tema principal e suas elaborações determinam o esboço ou contorno de todo um movimento é intrínseca ao próprio conceito, então vigente, de "melodia”, enquanto grande linha contínua. A idéia principal que esta generosa melodia contém é seu Hauptsatz, seu contorno mais definido, o tema principal que enuncia e que elabora no transcorrer de todo o discurso. A capacidade do compositor em sustentar tal idéia principal por todo o movimento, quer seja por reiteração, quer por confrontação, é extremamente aparentada à de manter uma firme argumentação durante todo o discurso, na oratória. Também este pressuposto recomenda uma relativa economia de conteúdos, pois a coerência formal, pré-requisito para a inteligibilidade desejada, depende substancialmente da técnica de elaboração temática. Coerência e inteligibilidade possuem, sob esta ótica, preponderância hierárquica sobre qualquer esquema formal pré-concebido.

Mesmo o nascimento e a utilização de um tema secundário ou subsidiário podem ser reinterpretados, então, à luz dessa nova perspectiva. Embora possa o tema secundário apresentar-se, de fato (embora nem sempre), contrastante, tal contraste nasce à luz de enfatizar e realçar os aspectos do argumento principal. É sob a doutrina estética da "unidade na variedade” que pode ser justificada a presença de um tema contrastante.

\footnotetext{
45 "Thus it follows that melody is the essential element of any work of music, and that harmony, in spite of its great importance and however much it increases the artistic means of expressivity, must nevertheless be subordinate.”
} 
Acerca do Hauptsatz, Johann Georg Sulzer (1720-1779) assim se pronunciou em Allgemeine Theorie der schönen Künste (1771-74):

Um Hauptsatz é um período dentro de uma obra musical que incorpora a expressão e toda a essência da melodia. Aparece não somente no início de uma peça, mas é freqüentemente repetido em diferentes tonalidades e diferentes variações. O Hauptsatz é geralmente denominado "tema", e Mattheson compara-o não inapropriadamente ao texto de um sermão, que deve conter em poucas palavras aquilo que o discurso desenvolverá mais amplamente. ${ }^{46}$ (SULZER apud BONDS, 1991, p. 94)

Acrescentemos que a invenção de um tema adequado e sua posterior elaboração têm como finalidade dar ao ouvinte o tempo necessário para que ele (o ouvinte) seja devidamente transportado ao estado emocional desejado pelo compositor, o que simples repetições não permitem realizar, pois que se tornam cansativas. Não se trata apenas de enunciar um tema que possua a expressão desejada, trata-se de reiterar e elaborar tal tema para que esta expressão seja devidamente absorvida. Organizar este tempo necessário à absorção constitui-se em caracterizar a forma, segundo uma finalidade pretendida. Ainda uma vez, agora via melodia, a forma erigida como função da retórica.

Por esta via a importância do conceito de Hauptsatz vai, também, estender-se até os gêneros, regulando suas especificidades segundo um conceito melódico e elaborativo, mais do que a partir de um conceito formal abstrato, que a eles se imponha:

É desta maneira que a forma da maioria de nossas correntes obras musicais usualmente tem surgido: concertos, sinfonias, árias, duetos, trios, fugas, etc. Todas elas têm isto em comum: são baseadas em um Hauptsatz apresentado num período principal breve e apropriado à expressão de um sentimento; que este Hauptsatz é apoiado ou interrompido por pequenas idéias interpoladas [Zwischengedanken] a ele apropriadas; que este Hauptsatz e estas Zwischengedanken são repetidas sempre suficientemente, em diferentes harmonias e tonalidades, e com pequenas variações

\footnotetext{
46 "A Hauptsatz is a period within a musical work that incorporates the expression and the whole essence of the melody. It appears not only at the beginning of a piece, but is repeated frequently, in different keys and with different variations. The Hauptsatz is generally called the 'theme', and Mattheson compares it not inappropriately to the text of a sermon, which must contain in a few words that which the discourse will develop more fully."
} 
melódicas, até que o espírito do ouvinte seja suficientemente cativado. ${ }^{47}$ (SULZER apud BONDS, 1991, p. 95)

Os gêneros assim são chamados por referirem-se a determinado universo musical, aparentado à sua finalidade. Para uma sala pequena não se escreve uma sinfonia, mas um dueto ou um quarteto de cordas. Para uma igreja (na qual tradicionalmente não se louvam valores profanos), danças são menos adequadas do que missas. Também a instrumentação acompanhava a finalidade proposta. Os trombones, por exemplo, que não estão presentes nas sinfonias de Mozart e Haydn (e são apenas utilizados por Beethoven a partir de sua quinta sinfonia), estão presentes no Réquiem e em A Flauta Mágica, ambos de Mozart, por serem adequados ao universo sacro e às revelações iniciáticas, ou seja, a utilização dos três trombones tem função simbólica.

Quanto às formas notemos, entretanto, que um conceito abstrato de forma, utilizado indiscriminadamente, nega, em princípio, as diferentes adjetivações que um gênero demanda. Utilizar um mesmo tipo formal, por exemplo, um rondó, abstratamente concebido, num movimento final de uma sinfonia, de um quarteto de cordas ou mesmo na parte final de uma missa (como às vezes faz Mozart, por exemplo, no Dona nobis pacem) parece ser tarefa desprovida de sentido, dadas as finalidades envolvidas. Entretanto, se a melodia desenvolve-se coerentemente, sendo devidamente liderada por um Hauptsatz pertinente ao gênero utilizado, o padrão “rondó” não pode ser fixamente concebido, mas retoricamente orientado, adequando-se ao contexto em que se encontra, o que permite sua utilização eficiente nos diferentes casos citados. Assim sendo, a forma sonata dos primeiros movimentos das sinfonias, quartetos, concertos solistas, sonatas e outros, não pode ser tomada como tipologia formal fixa, como molde que se impõe aos gêneros, mas, pelo contrário, como elaboração dirigida ao objetivo a ser alcançado. E tal inteligibilidade é, em grande parte, papel da melodia, contínua e fluente, que tem no Hauptsatz a enunciação de seu caráter fundamental.

Esta perspectiva é a postura preponderante durante todo o século XVIII no que diz respeito às distinções entre forma e gênero, e relembra as adequações necessárias

\footnotetext{
47 "It is in this manner that the form of most of our usual current musical works has arisen: concertos, symphonies, arias, duets, trios, fugues, etc. They all have this in common: that they are based on a Hauptsatz presented in a main period, brief and appropriate to the expression of a sentiment; that this Hauptsatz is supported or interrupted by smaller, interpolated ideas [Zwischengedanken] appropriate to it; that this Hauptsatz and these Zwischengedanken are repeated often enough, in different harmonies and keys, and with small melodic variations, so that the spirit of the listener is sufficiently captivated.”
} 
aos diversos gêneros (deliberativo, judiciário, epidíctico) propostas por Aristóteles. E se, na visão aristotélica, determinados argumentos e sua organização eram mais afins a determinado gênero, também

Numa obra musical, a natureza de um Hauptsatz e sua subseqüente elaboração igualmente variam de gênero para gênero. Os teóricos do século XVIII conceberam os gêneros não apenas baseados em sua função e instrumentação, mas também de acordo com a maneira pela qual suas idéias temáticas eram elaboradas. O gênero, em outras palavras, é em parte determinado pela melodia, ao menos na visão oitocentista de tal termo. ${ }^{48}$ (BONDS, 1991, p. 118)

Notemos, porém, que o conceito retórico de forma musical não se assenta apenas sobre a preponderância temática. Esta é uma de suas faces, por certo importante, mas não única. A disputa entre plano harmônico e plano temático, já por nós referida, e sua intercambialidade com o conceito de Hauptsatz somente podem ser apaziguados pela atenção dada ao conceito ora apresentado para o termo "melodia", como tencionamos ter revelado. A harmonia é, na verdade, o menor denominador comum às formas, o que não significa que seja a referência a este parâmetro que guie prioritariamente o discurso musical, em sua busca pela expressividade emocional. A forma não se conceitualiza pela descrição de seu principal denominador comum apenas, mas também pelo que, em cada caso, a torna pertinente. A maleabilidade do discurso melódico é traço da maleabilidade formal e, portanto, fator integrante de sua pertinência.

Tradicionalmente, o ritmo é tido como elemento primitivo (sem qualquer conotação pejorativa), corporal, afeito essencialmente à coordenação motora. O timbre refere-se ao universo sensório, cuja resposta não pode ser dita motora nem racional, originalmente. Já a harmonia, em que pesem suas inegáveis características expressivas, fala primordialmente ao mundo racional, porque feita de razões, proporções. À melodia cabe, pois, preponderantemente, o universo emotivo, por excelência. Entendidas as intersecções possíveis, mas obviamente aqui não exauridas, tais aspectos coadunam-se à função do parâmetro melódico presente no conceito retórico de forma musical.

\footnotetext{
48 "Within a work of music, the nature of a Hauptsatz and its subsequent elaboration similarly vary from genre to genre. Eighteenth-century theorists conceived of genres not only on the basis of their function and instrumentation but also according to the manner in which their thematic ideas are elaborated. Genre, in other words, is determined in part by melody, at least in the eighteenth-century sense of the term.”
} 


\subsubsection{0 - Expressão individual}

O sempre citado declínio da retórica durante o século XIX, ou de sua influência sobre o processo de composição e análise musical propriamente dito, teve início com sua retirada do currículo acadêmico. Nas artes, os pressupostos retóricos da persuasão foram considerados ultrapassados diante das então novas demandas, segundo as quais a arte teria como função primordial ser veículo da expressão individual.

Entretanto, a passagem da orientação pragmática para a expressiva e a anteposição de uma visão conformacional ante a uma generativa não se dão nem repentinamente, nem excludentemente. E muito provavelmente são mais dramáticas do ponto de vista analítico do que composicional propriamente dito. Aquilo que a perspectiva retórica havia acrescentado à linguagem musical não poderia ser simplesmente desprezado, mas os pressupostos analíticos podem, repentinamente, negligenciar importantes elementos. $O$ equilíbrio obtido entre uma visão conformacional e generativa de forma fora intermediado pelos preceitos retóricos, mas retórica era disciplina em franco declínio, cujos pressupostos precisavam ser superados. Tem início a emergência de um conceito abstrato de forma e, com ele, o paradoxo conceitual a que nos referimos anteriormente.

A centralização da arte no indivíduo e em sua necessidade de expressar-se, embora significando um reconhecimento da capacidade intelectual e artística dos “grandes vultos”, teve seus revezes. Ao alçar os compositores a um patamar social mais elevado, retirando-os da condição de meros artesãos a serviço da igreja ou de uma corte e elevando-os a respeitados (e por vezes idolatrados) membros de uma sociedade, concomitantemente se retirava, aos poucos, o papel que o ouvinte havia desempenhado durante todo o século XVIII. Também isto contribuiu para o enfraquecimento dos preceitos retóricos. Não se tratava mais de reunir os espíritos de toda a audiência e encaminhá-los a uma expressão desejada, mas de fazer desejada a expressão única do compositor. No primeiro caso é função do compositor fazer-se persuasivo para que convincente; no segundo, é função da platéia desvendar os segredos comunicados, bem como é de sua responsabilidade ser capaz de fazê-lo.

O reconhecimento de uma genialidade inata no compositor também enfraqueceu a perspectiva retórica do processo composicional como algo que poderia ser ensinado, justificando seu suposto abandono (o da perspectiva), e mesmo a invenção dos temas passa a ser habilidade menos passível de ser adquirida do que fora no século XVIII. Mas 
como podem os tipos formais, enquanto padrões, imporem-se justamente num momento de tal exacerbada individualidade? Não seria descabido afirmar que a expressão individual romântica tenha aceitado submeter-se a um padrão formal convencional?

A aceitação de música como linguagem autônoma significou, de início, que ela devesse organizar-se segundo seus próprios elementos, desprezando sua conexão com as palavras. Derivar da retórica tal organização não seria mais aceitável, pois pressupunha a continuidade da metáfora da oração. E o próprio termo, então, deixa de ser utilizado, pois expressar-se em termos da retórica passa a significar estar atrelado a algo antigo, do passado, já superado. ${ }^{49}$ A verificação dos padrões musicais recorrentes deve, então, fornecer os subsídios para a elaboração de tipos formais básicos, preponderantes. O nascimento deste conceito abstrato de forma, amparado na delimitação destes tipos formais, não constitui, por si mesmo, problema algum. Entretanto, o esquecimento de sua ascendência retórica e a negligência para com os conteúdos é que dirigem a análise formal à tendência de encaixar as obras num dos moldes estruturais propostos, o que não parece ter se imposto ao processo composicional. E se a forma, enquanto conceito abstrato, é apenas uma referência para o compositor e não uma vestimenta na qual ele deva, obrigatoriamente, fazer caber o corpo de sua obra, então o compositor conforma a forma à sua maneira. Logicamente, cabe à análise musical munir-se dos mesmos pressupostos.

Assim vista, a expressão individual não é escrava das convenções, mas utiliza-se delas em proveito próprio. O compositor do século XIX não aceitou submeter-se a padrões convencionais, mas utilizou-os como paradigmas para a veiculação de sua individualidade. E, ao aceitar tal paradigma, implicitamente corroborou a inteligibilidade que perpassara a criação de tais tipos formais. Mesmo à luz de profundas mudanças, um dos ingredientes básicos da retórica adentrou o século XIX, mas no lugar da oratória teve vez a metáfora do organismo biológico.

\subsubsection{1 - A metáfora do organismo e o declínio da retórica}

O século XIX assistiu a uma paulatina mudança no enfoque dado à forma musical. Durante a primeira metade deste século, a metáfora da oração foi sendo

\footnotetext{
${ }^{49}$ Há, pois, uma corrente conotação pejorativa sobre o termo "retórica”, como discurso deveras alongado e sem conteúdo, ou sobre a ineficiência de tal discurso em converter-se em realizações práticas.
} 
substituída, gradualmente, pela visão de forma como um organismo. Assim como num organismo a forma final é determinada pela aglomeração das mínimas unidades (células) que o constituem, também na música as pequenas células sobrepõem-se sucessivamente, dando origem a um "organismo musical”, que cresce e se desenvolve segundo suas próprias características. Pelo fato de a forma final e as partes de que é composta serem já de antemão totalmente congruentes, oriundas de uma mesma matriz genética, tal comparação imediatamente reporta-se à questão da coerência entre partes, e das partes com o todo. O crescimento organizado e proporcionado dos organismos também se remete à proporcionalidade pretendida para as seções da obra musical, e o fato de que a metáfora seja a partir de “algo que vive”, traz à música uma rica simbologia: a música respira, a música se move, a música vibra. Em lugar de ser uma linguagem, a música é quase "vivente”. Historicamente o conceito de obra de arte nasce aqui e, num vocabulário “purista”, nem deveríamos ter utilizado o termo “obra” para designar uma composição musical anterior a este período.

Sob diversos aspectos essa metáfora do organismo guarda relações com a perspectiva retórica e, sob outros, ela a amplia ricamente. Se o que "cresce" num movimento musical é sua idéia principal (seu tema), a relação com a retórica estabelecese imediatamente. É a idéia temática quem germina, multiplicando-se e gerando frutos. Se a música é uma estrutura orgânica, ela também deve possuir um espírito que a anime e a faça nobre. As elaborações são verdadeiras metamorfoses a que o material musical é submetido. Até aqui, as comparações se afirmam e se relacionam mutuamente. Sendo tácito que todo acréscimo é bem vindo, resta-nos observar em que pontos a comparação com um organismo contradiz os preceitos retóricos e se essas contradições retiram-lhe algum aspecto fundamental, que a retórica havia preservado.

No fim, entretanto, a nova metáfora reflete uma profunda mudança na perspectiva estética. Como um organismo, a obra musical é um objeto de contemplação que existe em e a partir de si mesma. Como uma oração, a obra musical é um evento temporal, cujo propósito é evocar uma reação do ouvinte. Nós podemos ser movidos por ambos os modos de experiência; mas a metáfora da oração necessariamente enfatiza a temporalidade da obra, o papel do ouvinte e o elemento da persuasão estética, enquanto o modelo do organismo biológico não tem necessidade de considerar o efeito da obra sobre a audiência a que se destina. Além disso, a audiência, por todos seus propósitos práticos, é irrelevante para o modelo 
orgânico. A metáfora orgânica implica que os critérios pelos quais qualquer obra dada deva ser julgada serão encontrados dentro da obra mesma. Este tipo de pensamento uma vez mais reforça a autonomia conceitual de ambos, a obra de arte e o seu processo de criação, pois a metáfora biológica tacitamente encoraja-nos a ver o artista como uma força vitalmente concedida [como um 'dom' natural]. ${ }^{50}$ (BONDS, 1991, p. 145)

O que a retórica musical houvera logrado superar, enquanto resposta adequada às relações entre forma e conteúdo, evitando que os conteúdos determinassem exclusivamente o caráter da forma e, simultaneamente, cuidando para que a forma não se impusesse ao conteúdo deformando-o, renascia em meados do século XIX. As perspectivas conformacional e generativa não puderam mais ser coordenadas em suas intersecções, mas restaram novamente antepostas. O declínio da retórica também significou um afastamento entre práticas analíticas e processo composicional e, por fim, legou-nos conceitos de análise formal que se querem procedentes para todo o repertório quando, na verdade, embora se façam pertinentes a grande parte deste, não podem abarcá-lo indiscriminadamente.

Não são os preceitos retóricos a chave para a resolução de todos os problemas no que tange aos processos composicionais ou analíticos, a verdade nunca mora apenas em um mesmo lugar. Mas o que for de sua alçada e competência não deve ser menosprezado, porém unido a novas abordagens sob critérios igualmente pertinentes. $\mathrm{O}$ paradoxo que se abate sobre o conceito de forma e suas conseqüências é um embate travado substancialmente a partir do declínio da retórica.

\footnotetext{
50 "In the end, however, the new metaphor reflects a profound shift in aesthetic outlook. As an organism, the musical work is an object of contemplation that exists in and of itself. As an oration, the musical work is a temporal event whose purpose is to evoke a response from the listener. We can be moved by both modes of experience; but the metaphor of the oration necessarily emphasizes the temporality of the work, the role of the listener, and the element of aesthetic persuasion, whereas the model of the biological organism has no need to account for a work's effect upon its intended audience. Indeed, the audience, for all practical purposes, is irrelevant to the organic model. The organic metaphor implies that the standards by which any given work is to be judged will be found within the work itself. This kind of thinking further reinforces the conceptual autonomy of both the work of art and the process of its creation, for the biological metaphor tacitly encourages us to see the artist as a life-giving force.”
} 


\section{6 - Análise do $1^{\circ}$ movimento da Sonata $n^{\circ} 8$ em dó menor, opus 13, - "Patética” - L. V. Beethoven (1770-1827)}

A análise formal a que procederemos pretende evidenciar a relação entre os planos harmônico e temático e os pressupostos retóricos que abordamos. Não se pretende uma descrição das figuras retóricas, cuja identificação não é o foco de nosso trabalho. Tampouco nos queremos como inovadores de conceitos analíticos, não propomos a negação da análise formal tradicional. Tenciona-se, isso sim, identificar os aspectos formais e discursivos que, embora detectados comumente, não são percebidos como preceitos retóricos. Ao promover a relação entre aspectos formais e sua orientação retórica primordial, pretendemos corroborar a tese central de nosso estudo, a percepção da origem retórica das formas musicais.

Dedicada ao Príncipe Carl von Lichnowsky, a composição da Grande Sonata Patética foi concluída em 1798, e sua publicação data de 1799. Pode-se considerar que esta sonata estabeleceu, em definitivo, a reputação de Beethoven como grande compositor. A obra possui três movimentos, sendo o primeiro construído como forma sonata, o segundo (Adagio cantabile) em forma rondó (simples), com um célebre tema lírico, e o terceiro (Allegro) constituído como um rondó sonata. A presente análise do primeiro movimento pretende relacionar os planos harmônico e temático aos fundamentos retóricos expostos.

\subsection{1 - Introdução (exordium): compassos 1-10}

O acorde inicial, em região grave e posição cerrada, é constituído de sete notas. Pela região acústica escolhida e pela utilização do fp estabelece imediatamente o caráter geral da introdução. Os ritmos pontuados caminham para uma tétrade diminuta que resolve sobre a dominante. Este padrão será repetido nos compassos 2-3, com reiteração ao final do $3^{\circ}$ compasso. Compasso 4 alarga o padrão ritmicamente, enquanto conduz a melodia ao láb (ponto culminante até aqui) que, tornado $7^{\mathrm{a}} \mathrm{m}$ do sib grave (ponto mais grave até aqui) declama melodicamente, estabelecendo a dominante de mib maior (III de dó menor, ou relativa). Esta seqüência melódica do $4^{\circ}$ compasso contrapõe-se à textura coral-homofônica que predomina nos compassos 1-3. 


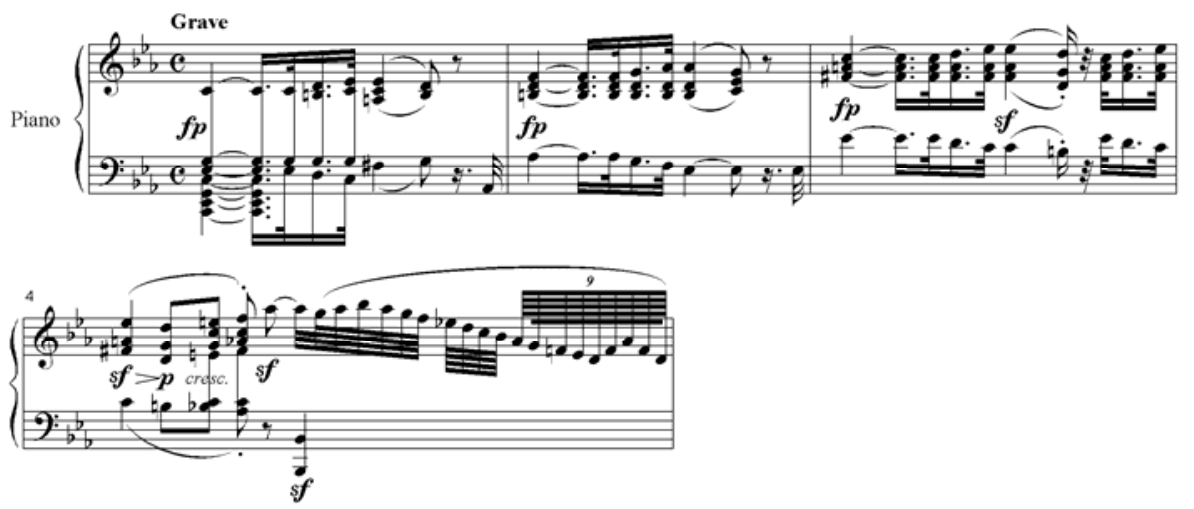

Figura 1

Os compassos 5-6 utilizam os ritmos pontuados alternadamente em perguntas (na região aguda, em $p$ ) e respostas (na região grave, em ff), estabelecendo um diálogo; compassos 7-8 desenvolvem a pergunta deste diálogo e promovem o retorno a dó menor. Compasso 9 possui cadência de engano em dó menor, seguida de longa pausa expressiva (notar que ambos os procedimentos levam em consideração o papel do ouvinte, pressupondo as reações da audiência); o compasso 10 reitera e amplifica o pensamento melódico sobre cadência perfeita em dó menor, com escala cromática descendente varrendo a tessitura da mão direita em direção à $7^{\mathrm{a}}$ dim que caracteriza a tonalidade. Este último compasso assume um caráter não mesurado, mas declamatório.

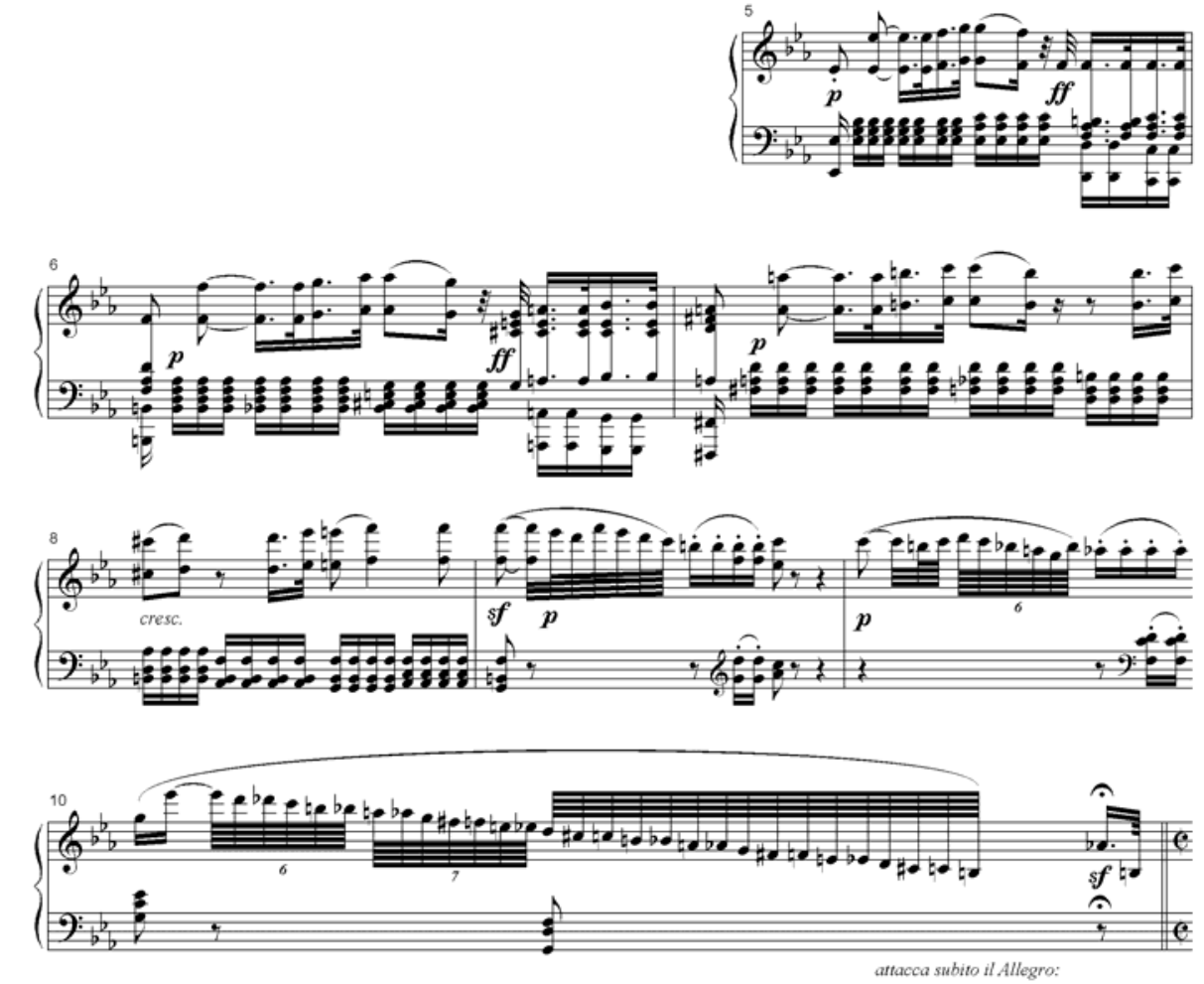

Figura 2 
Os aspectos predominantes desta introdução (exordium) são a harmonia densa, com ampla utilização de tétrades diminutas, contraposta aos desenhos melódicos rapsódicos. Tais aspectos são reforçados pelas dinâmicas, acentos e tessituras adicionadas, compondo o caráter Grave desta introdução. A contraposição da densidade harmônica à declamação melódica, valorizada por pausas, cadência de engano e concluída pela fermata sobre o láb (compasso 10) que valoriza a $7^{\mathrm{a}}$ diminuta característica da tonalidade, exige a atenção do ouvinte, unindo os ânimos do auditório num silêncio que emoldura as expectativas. Está expresso o caráter de exordium segundo os preceitos retóricos.

\subsection{2 - Exposição (propositio): compassos 11-132}

Adoção do Allegro di molto e con brio (com attacca subito), em oposição ao Grave inicial. Tema principal exposto em dó menor nos compassos 11-18 e reiterado nos compassos 19-26 (agora com término sobre a dominante). As características principais do tema são: 4 primeiros compassos com desenho ascendente (em staccato) sobre baixo pedal à maneira de um tremolo, seguidos por 4 compassos em mínimas descendentes (também em staccato), nos quais o tremolo abandona o pedal e caminha por movimento ascendente, valorizado por um crescendo. O caráter deste primeiro tema supõe agitado movimento.

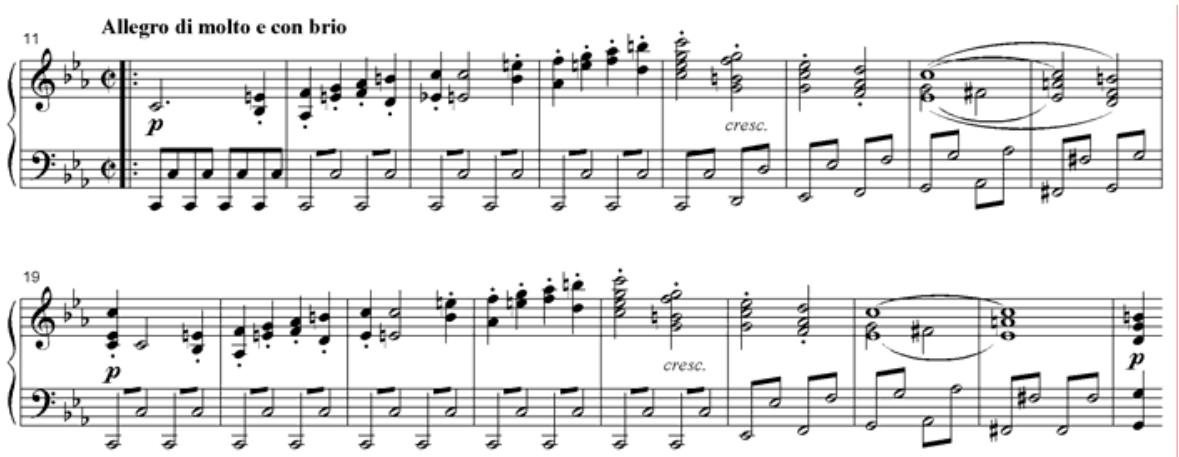

Figura 3 
Os compassos 27-34 possuem material agregado ao tema principal, com menor ênfase harmônica dada à tônica, por apoiarem-se teticamente sobre a dominante, deixando a tônica sobre parte átona. A afirmação do argumento principal perde vigor. É procedimento retórico para permitir a entrada de novos materiais.

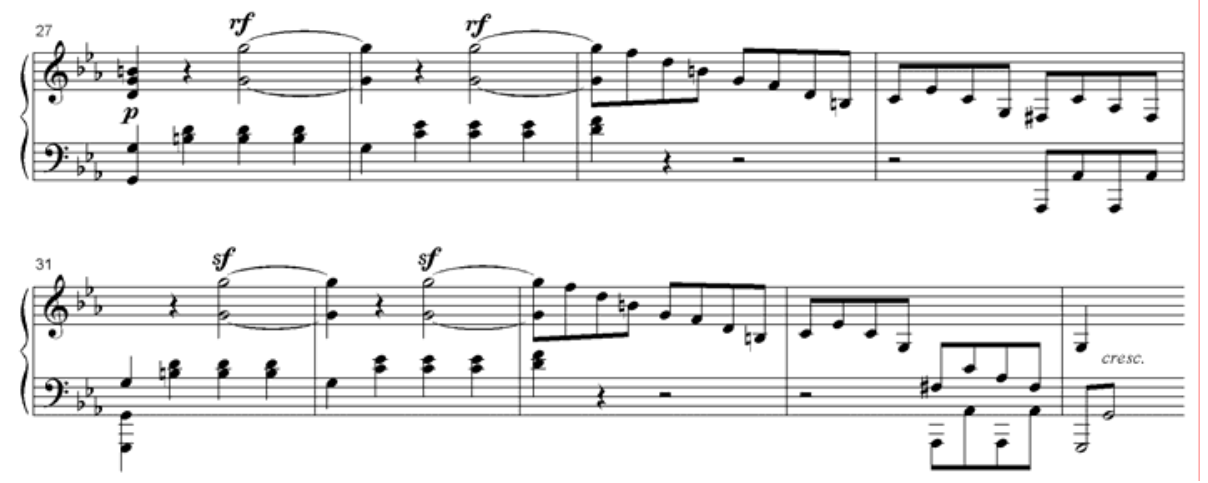

Figura 4

A transição se dá nos compassos 35-50, com a utilização de progressões harmônicas desenvolvidas sobre material do tema principal. Tais progressões apontam para a dominante de mib maior, com a presença do sib no tremolo de mão esquerda. Compassos 35-44 geram aumento de tensão em direção à dominante, enquanto compassos 45-50 promovem gradual relaxamento em movimento descendente, com abandono do tremolo e apoio melódico do sib por semitom em 49-50. Está aberto o caminho para a aceitação de um novo argumento.

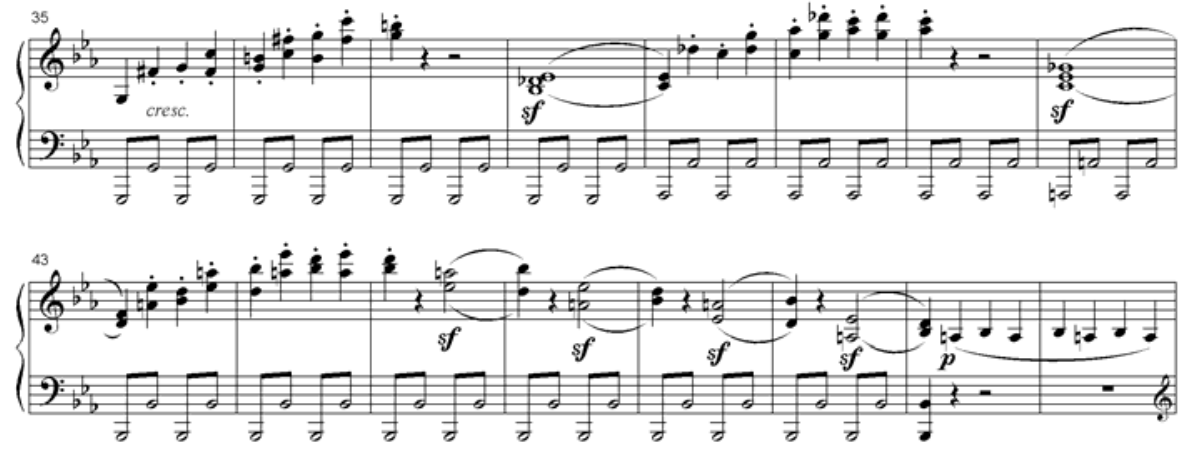

Figura 5 
O tema secundário surpreendentemente vem à tona em mib menor, ao invés do maior aguardado (embora o compasso 42 já houvesse citado um solb como $7^{\text {a }}$ diminuta, ainda que um dob não tenha sido providenciado). Tal escolha beethoveniana provavelmente deve-se ao desejo de expressar reiteradamente o caráter patético, e a pretendida finalidade justifica a variação sobre o plano harmônico original que o tipo formal prevê, estando, pois, retoricamente justificada.

Observemos que o tema secundário é constituído por um acompanhamento em região central ( $3^{\mathrm{a}} \mathrm{s}$ sobre um pedal da $\left.5^{\mathrm{a}}\right)$ e uma melodia em staccato em região aguda, sempre previamente introduzida pela região grave (mão direita cruzando sobre a esquerda), que inclusive anuncia as mudanças harmônicas. O movimento ascendente, valorizado pelas appoggiaturas (saltos ascendentes de $6^{\mathrm{a}}$ ), encontra resposta nas ligaduras descendentes (duas a duas), ornamentadas pelos mordentes. A textura resultante é mais leve e menos afirmativa do que a do tema principal. A ausência de uma voz grave claramente delineada e acusticamente decisiva oferece contraste evidente ao tremolo presente no tema principal.

Sobre este material, a harmonia evolui de mib menor (compassos 51-62) a réb maior (compassos 63-75), através da reinterpretação de mib menor em 61-62 (I de mib menor = II de réb maior); notemos ainda que réb maior é napolitana da tonalidade principal.
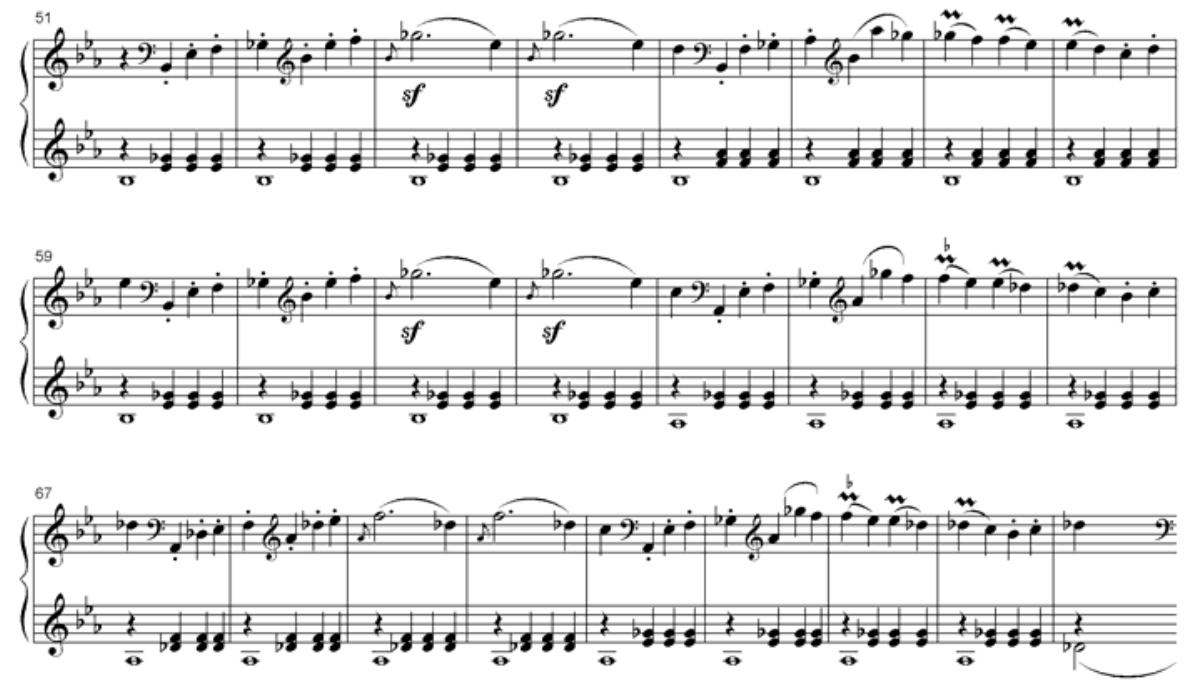

Figura 6 
Compassos 75-88 promovem volta a mib menor, apontam a região de fá menor (compassos 80-83) e decidem sobre mib, agora finalmente maior, com insistente utilização dos mordentes em decrescendo que leva ao pp.

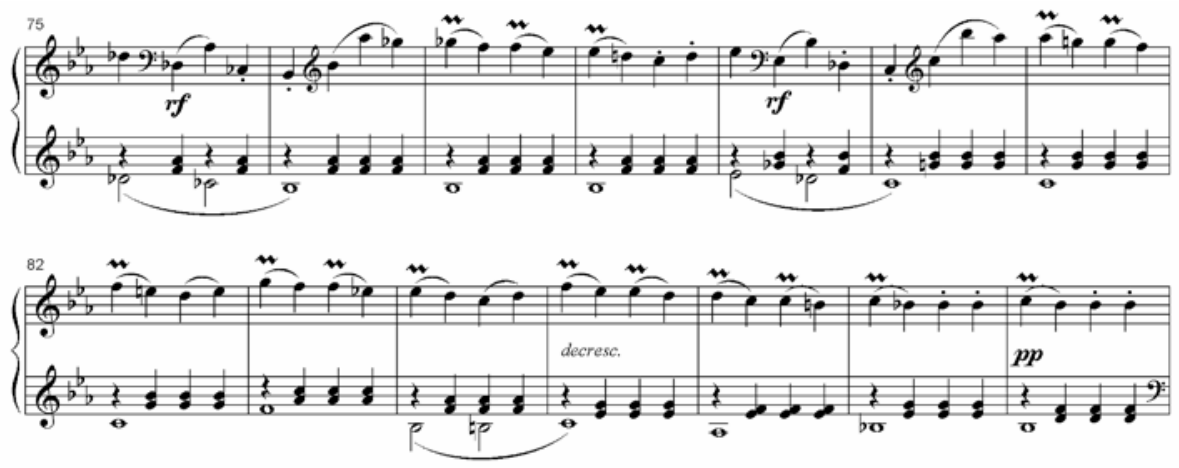

Figura 7

Um primeiro material agregado ao tema secundário, exposto nos compassos 89113, é constituído de arpejos espelhados na região central, sobre e sob os quais caminham os movimentos contrários das vozes externas, que atingem seus ápices no compasso 98, cadenciando em mib maior (99-101); todo o trecho é repetido em 101113, com a conquista de mais alto ponto culminante em 111. Do ponto de vista da textura, este material estabelece uma condução harmônica em legato e promove um crescendo até atingir os pontos culminantes, neutralizando o caráter mais articulado do tema secundário.
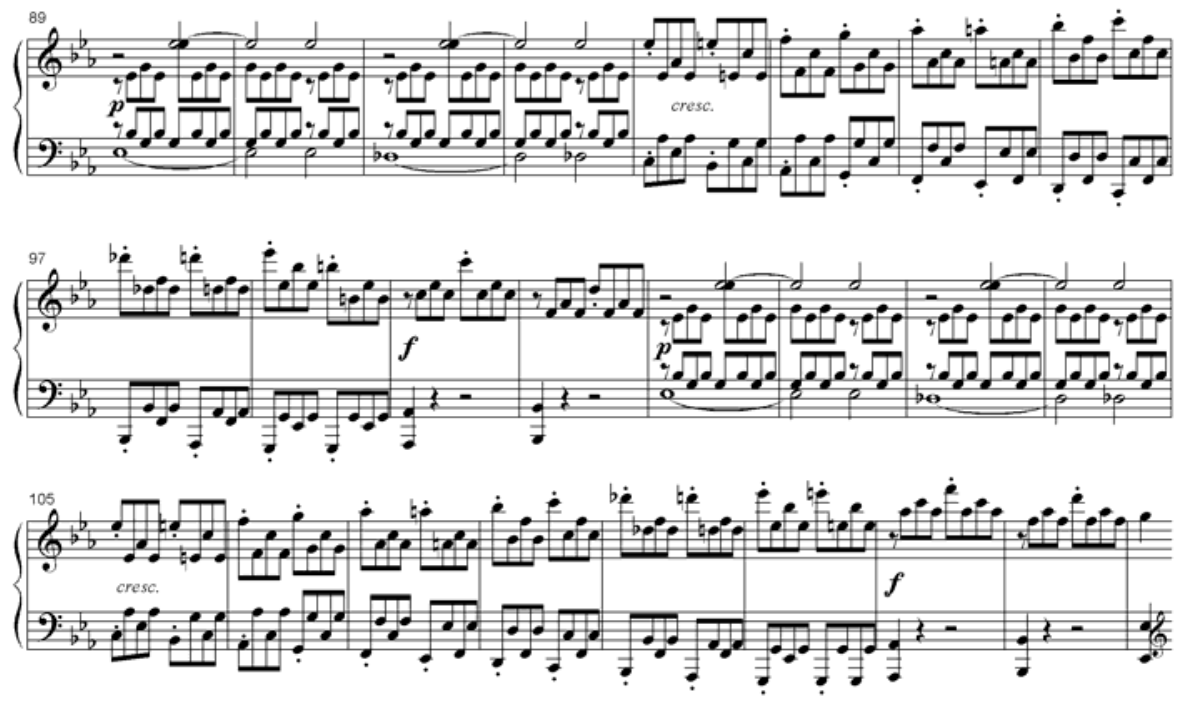

Figura 8 
Um segundo material agregado ao tema secundário tem lugar nos compassos 113-120 (também é possível tomar este material já como o início da codetta). Seu caráter é de apaziguamento: ao distender a tensão (originada pela chegada aos pontos culminantes) em larga e fluente melodia que conduz dos agudos conquistados ao conforto da região central, simultaneamente providencia cadência em mib maior. Nos compassos 113-116 tudo se passa sob dinâmica piano, ao passo que, em 117-120, um crescendo é providenciado para melhor integrar-se à codetta (compassos 121-132). Esta, claramente construída sobre o tema principal (mas em mib maior), apóia semibreves em $6^{\mathrm{a}} \mathrm{s}$ e $3^{\mathrm{a}} \mathrm{s}$, conduzindo à dominante de dó menor na casa 1 (para um ritornello) e à de sol menor na casa 2 (para a continuação).

Termina aqui a enunciação dos dois argumentos principais de que trata o discurso, e podemos denominar tal seção exposição, propositio ou narratio.

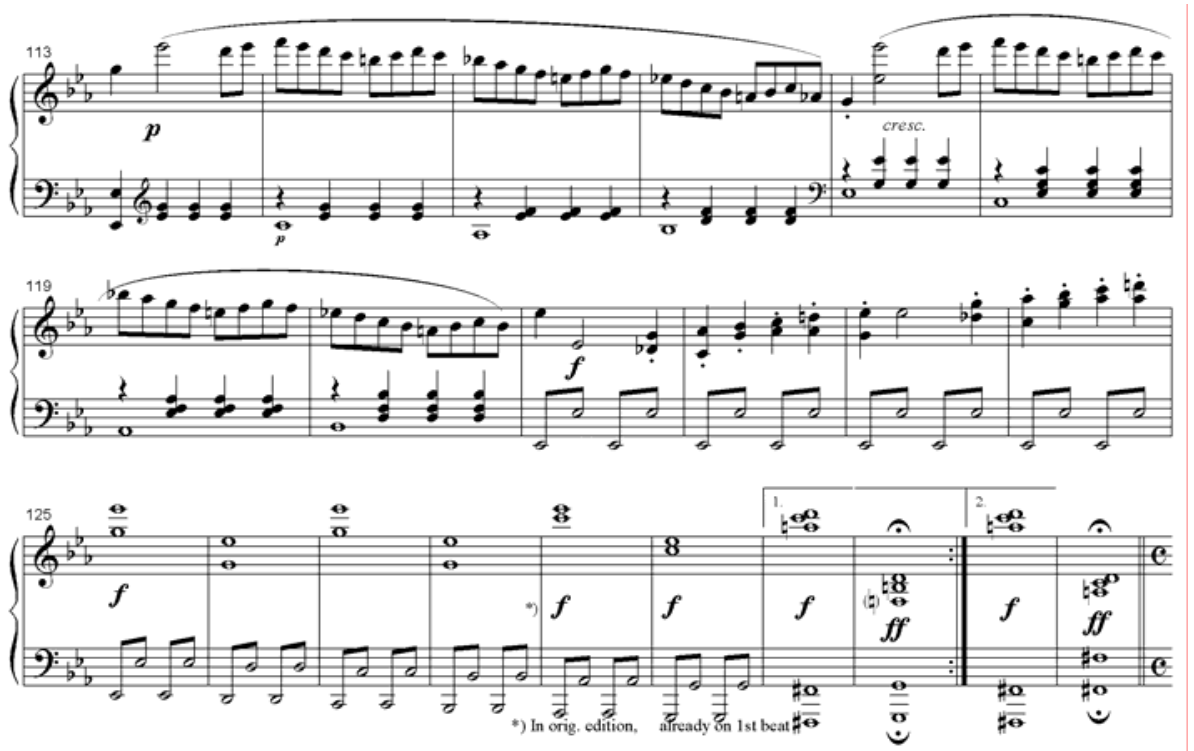

Figura 9 


\subsection{3 - Introdução (exordium) intercalada: compassos 133-136}

Tendo elaborado de maneira tão rica a introdução, Beethoven considerou-a como material a ser novamente abordado. Fazendo-a reaparecer entre o final da exposição e o início do desenvolvimento, deu-lhe, coerentemente, um papel harmônico condizente com a seção que agora preludiava. Nada mais retórico do que uma utilização inovadora do protótipo segundo finalidades expressivas. O conteúdo reforma o tipo formal sem corrompê-lo; antes, pelo contrário, revigora e enriquece o protótipo, respeitando suas proporções, e elevando-o a outro nível de coerência, exigido pelo conteúdo expressivo que deseja veicular.

Com o Tempo I retorna o Grave, e os compassos 133-134 são a exata transposição da introdução original para sol menor. O compasso 135 comporta uma enarmonização de mib por ré\#, o que permite a reinterpretação do VII de sol menor (fá\# diminuto) como VII de mi menor (ré\# diminuto), sobre cuja dominante termina esta “reintrodução". A dinâmica $p$ da metade de 135 decresce até $p p$ ao final de 136, exigindo a atenção do ouvinte. Novamente é expresso um caráter meditativo, que concentra as atenções. A expressividade do páthos criado pela modulação enarmônica é notável procedimento retórico.

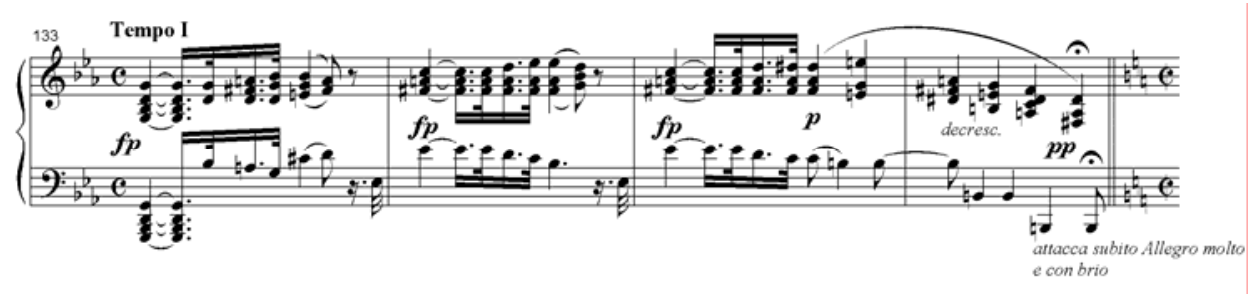

Figura 10

\subsection{4 - Desenvolvimento ou elaboração (confutatio): compassos 137-194}

O Allegro molto e con brio (novamente com attacca subito) inicia o desenvolvimento em mi menor, com utilização do tema principal (à maneira da transição) nos compassos 137-138, intercalado com o tema da introdução timbrado em oitavas (agora não mais pontuado) em 139-141. A figura de acompanhamento agora 
deriva do material agregado ao tema principal (comparar com compassos 27-28), o que lhe atenua o tom dramático enquanto intensifica o patético.

Esta progressão, abarcando os compassos 137-148, visita as regiões de mi menor e sol menor, mesma relação de terças menores entre tonalidades verificada entre os temas principal e secundário na exposição, portanto reiteração do procedimento retórico que fundamenta as relações entre tonalidades. Notar que os recortes temáticos envolvidos propõem um contraste de opiniões, sob argumentos alternadamente proferidos.

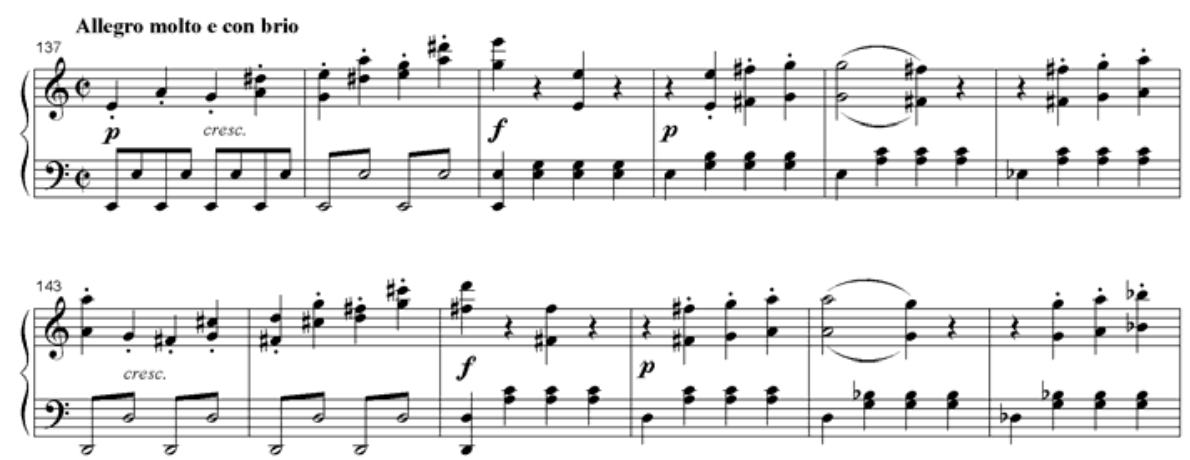

Figura 11

Os compassos 149-167 trazem a elaboração do tremolo (que originalmente alicerçava o tema principal à maneira de um pedal) agora em região aguda, enquanto a parte superior do tema principal reaparece na região grave, sob legato e não mais staccato, apoiando ao final das ligaduras (duas a duas) os arpejos sobre as dominantes.

Pode-se reduzir os compassos 149-162 a uma seqüência cromática descendente de diminutos (ou de maiores com $7^{\mathrm{a}} \mathrm{m}$ e $9^{\mathrm{a}} \mathrm{m}$ ), cujas fundamentais na verdade caminham sobre passos de $5^{a}$. Isso confere a este trecho um inequívoco caráter de instabilidade, próprio da confutatio. Percebamos ainda que a definição schoenberguiana destes acordes como “errantes” já revela sua ascendência retórica. Expliquemo-nos: por “errantes” entendemos acordes que podem conduzir a tonalidades diversas e por vezes afastadas (a exemplo dos "astros errantes”, cujas órbitas não são definidas ou conhecidas). A utilização dos acordes errantes promove a momentânea instabilidade dos centros tonais, o que nos remete à instabilidade típica da confutatio, na qual os argumentos são submetidos a confrontações, por vezes violentas. 
Uma longa descida do tremolo, com alusão à região de fá menor (IV de dó menor), conduz à cromatização em direção a sol, promovendo o retorno do pedal à sua região de origem.
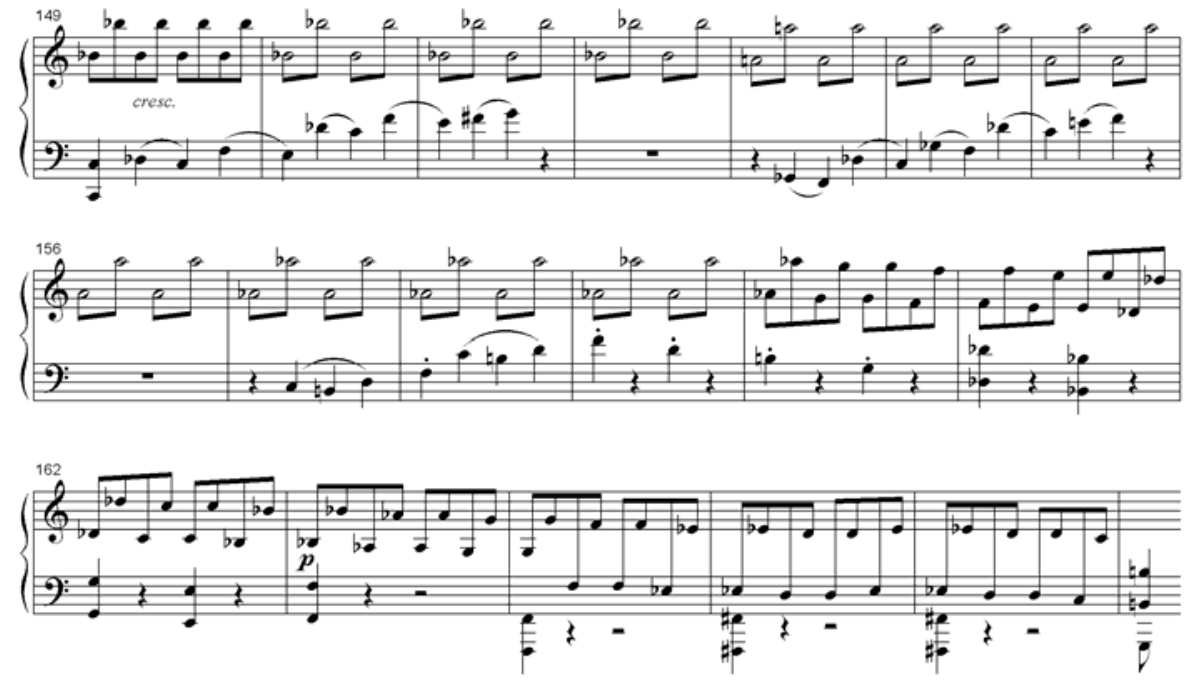

Figura 12

A partir de 167 e até 170 temos o pedal em sol sob um insistente láb (e esta 9am denota a função dominante do acorde, já prenunciando o dó menor). Internamente, arpejos escondem uma condução por terças paralelas (do\#-mi, ré-fá, do-mib, si-ré). Tal material, dada a complexidade da harmonia aliada à dissonância dos intervalos e à tessitura grave em que se encontra, realça certa “confusão”, confirmada pela ausência de proposta temática definida. Providencialmente, segue-se nova elaboração do tema principal (em 171-175) sobre o pedal de sol, preservando, entretanto, o caráter oscilatório.

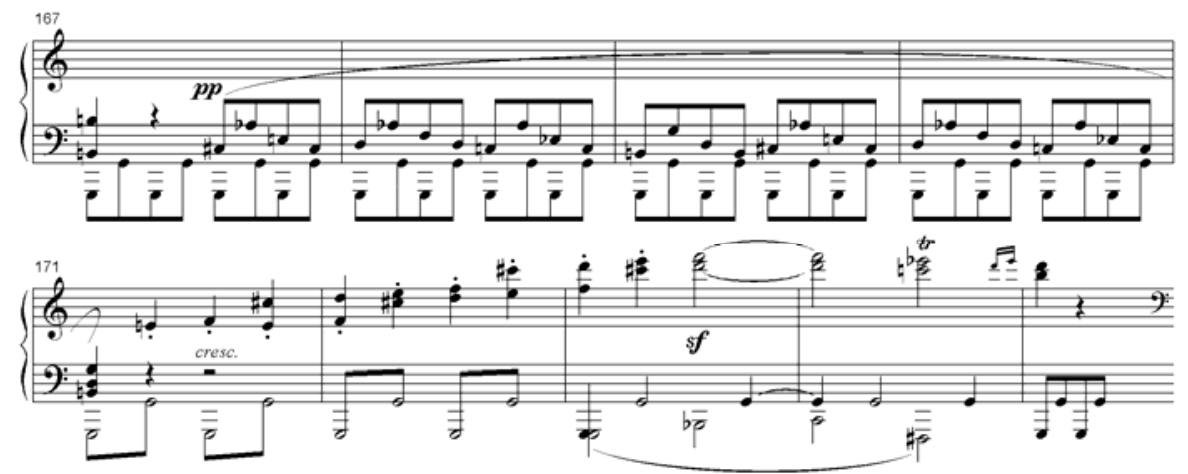

Figura 13 
Os compassos 167-174 são repetidos em 175-182, com a reiteração de 181-182 em 183-186. Segue-se longa seqüência melódica (compassos 187-194) que articula o arpejamento da dominante, enquanto conduz à tessitura de origem do tema principal. A expectativa é sustentada pela espera de um ponto final sobre o qual a melodia finalmente irá descansar, ao mesmo tempo em que a audição de uma única linha filtra a complexidade harmônica anterior, focando a atenção do ouvinte para o próximo passo.

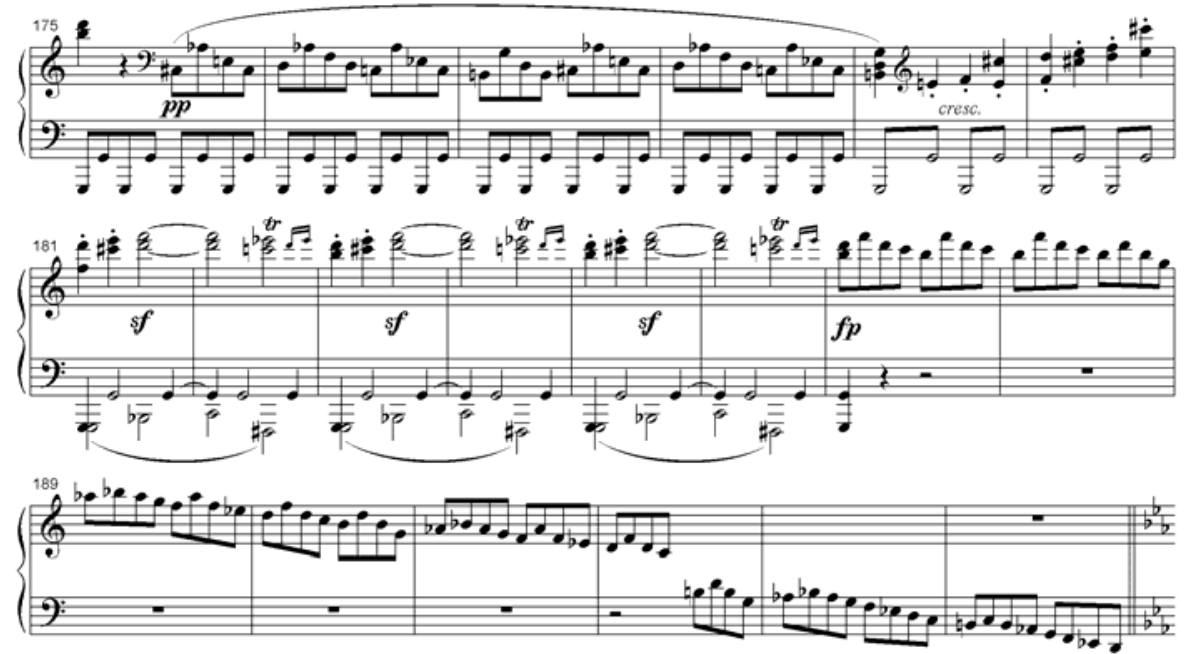

Figura 14

Não é supérfluo notar que o tema secundário, em seu principal contorno, não é elaborado no desenvolvimento, enquanto grande atenção é dada aos vários materiais que compõem o tema principal. Já os contornos da introdução são utilizados por pequena reiteração melódica e acentuada recorrência harmônica, com constante utilização dos acordes diminutos. Esta eficaz variação sobre a utilização tradicional dos temas no desenvolvimento sugere uma importância maior do material da introdução em relação ao tema secundário, o que explica-se pelo fato de a introdução sobrepujar o tema secundário no que tange à expressão de um caráter patético. Tal finalidade expressiva (retórica) criou pressupostos válidos para estes procedimentos no desenvolvimento. Por razões de coerência, o desequilíbrio gerado pelo não aproveitamento consistente do tema secundário será “corrigido” pela utilização de seu motivo inicial no rondó do terceiro movimento que encerra a sonata. 


\subsection{5 - Reexposição (confirmatio): compassos 195-310}

Inicia-se no compasso 195 a reexposição do tema principal, identicamente realizada até o compasso 207, quando tem lugar a reiteração dos acordes em mínimas em direção descendente. Este material, cujo padrão de quatro compassos é elaborado entre 207 e 218, promove amplificação harmônica para as regiões de réb maior (compassos 207-210), mib menor (compassos 211-214) e fá menor (compassos 215218), com material similar ao dos compassos $49-50$ reaparecendo em 219-220, agora indicando a modulação a fá menor, tonalidade na qual o tema secundário será reexposto. As regiões citadas (réb maior e mib menor) são referidas, mas, no momento de sua efetiva afirmação pelo acorde de tônica (que se daria nos compassos 211 para réb maior e 215 para mib menor), são contidas por cadências interrompidas que, ato contínuo, anunciam as subseqüentes regiões. O efeito é notável.

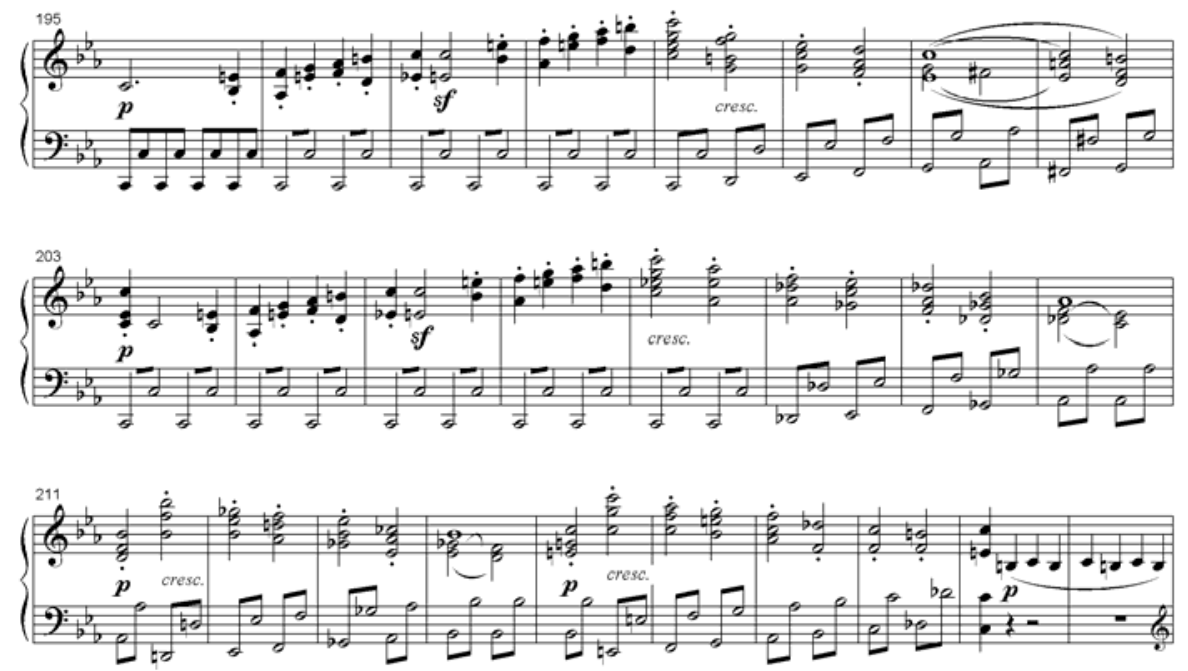

Figura 15

É importante ressaltar, ainda sobre o mesmo trecho compreendido entre 207 e 218 (e que se constitui na transição da reexposição), a utilização da parte final do tema principal, enquanto na exposição fora utilizada sua parte inicial (para a transição). Tal escolha se deve ao equilíbrio desejado na utilização dos materiais. Esta segunda parte do tema principal (os quatro compassos finais dos oito totais de que se compõe o tema) fora o argumento menos trabalhado durante o desenvolvimento, ao passo que o contorno inicial já havia sido exaustivamente elaborado, seja no desenvolvimento, seja como transição da exposição. 
Se a retórica pretende persuadir, faz parte de sua estratégia de convencimento não deixar que qualquer argumento ou parte de argumento utilizado fique sem sua devida contextualização, sob pena de mostrar-se inconseqüente. É importante notar como o compositor omitiu categoricamente o material agregado ao tema principal (presente nos compassos 27-34) e a parte principal do tema (seus quatro primeiros compassos), optando por dar relevo justamente ao que houvera sido menos desenvolvido. Construir sobre este material remanescente a transição da reexposição manifesta um senso retórico de equilíbrio entre argumentos e o controle lógico (musical) do que ainda não houvera sido devidamente explorado, mesmo após o desenvolvimento.

O tema secundário é reexposto sem grandes novidades quanto à utilização dos materiais, apenas o plano harmônico é diferente: fá menor (compassos 221-228) e dó menor (compassos 229-252).
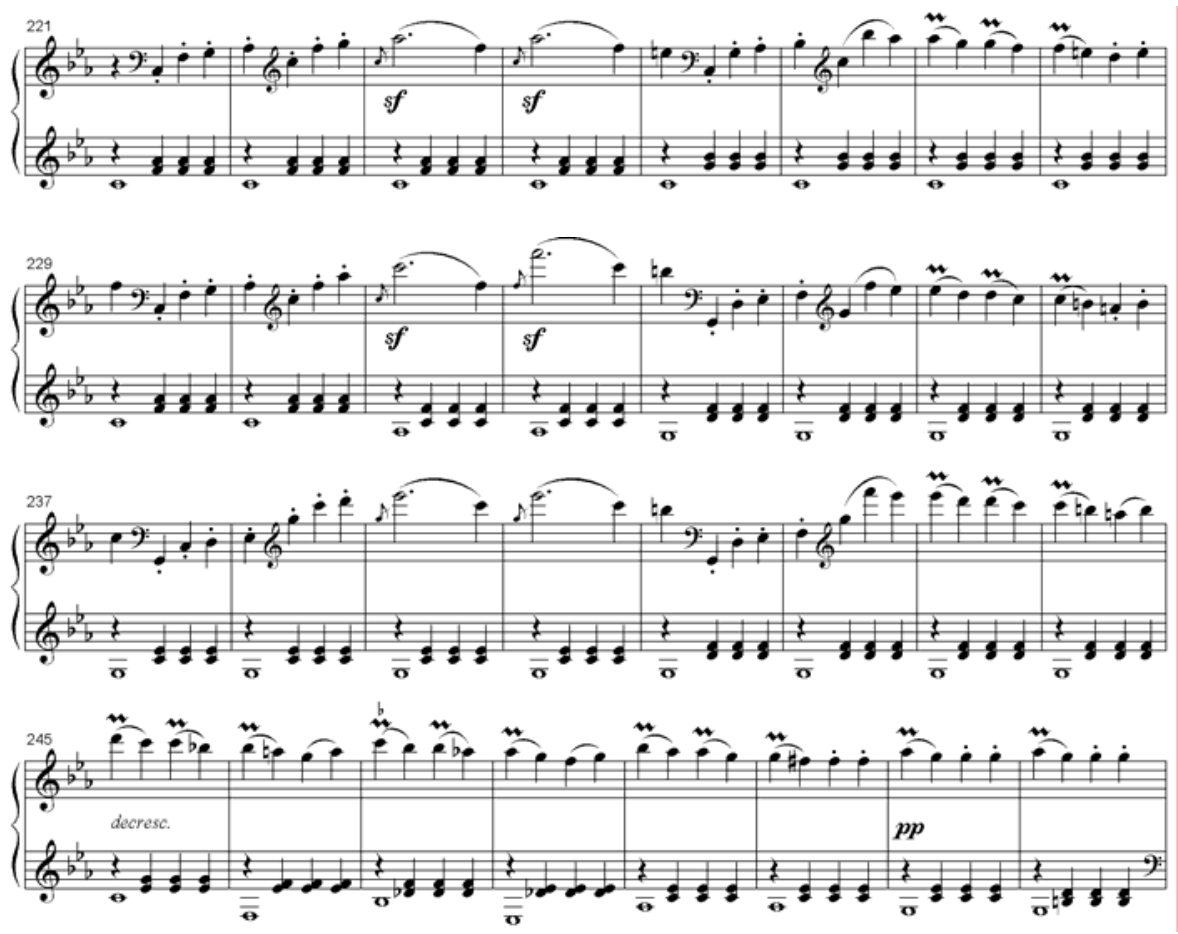

Figura 16 
O primeiro e segundo materiais agregados ao tema secundário e a codetta são respectivamente reexpostos nos compassos 253-276, 277-284 e 285-294, finalmente dobrando-se à tonalidade principal de dó menor (ante o mib da exposição).
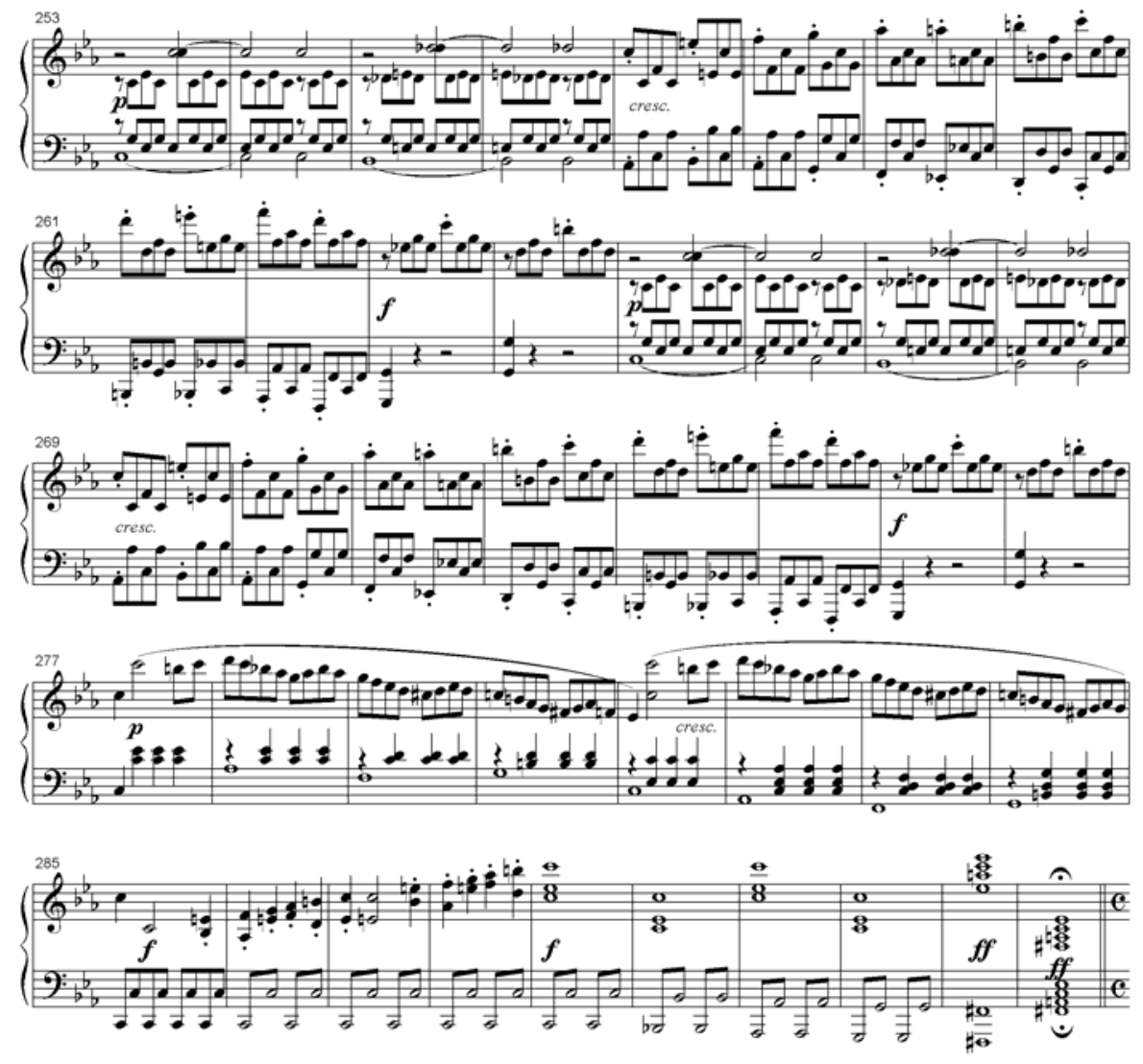

Figura 17

Uma última citação da introdução tem lugar nos compassos 295-298, renovando o caráter meditativo da obra. A novidade aqui introduzida é a substituição dos acordes téticos de cada compasso por pausas. A função retórica destas é indiscutível, pois estes silêncios, ao calarem os acordes, antes acentuam pela ausência uma presença reminiscente, audível em memória sob as pausas.

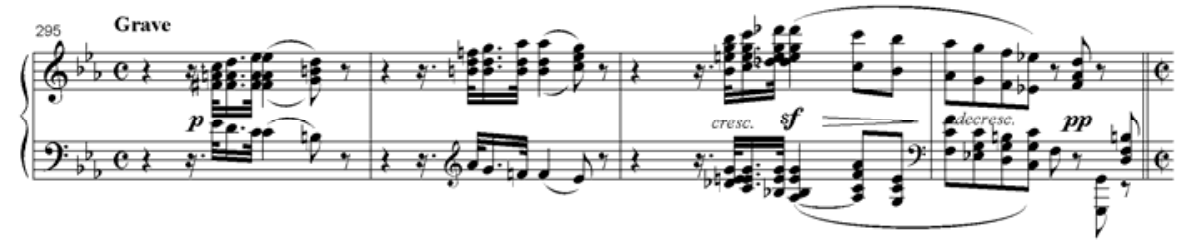

Figura 18 
Os compassos 299-310 permitem ao tema principal despedir-se como coda, enquanto o último acorde do movimento, no penúltimo compasso, apresenta-se escrito como o primeiro, em região grave e cerrada, e com sete notas. Destaque-se ainda o último compasso, fermata sobre pausa geral, ambivalente enquanto fecho de quadratura formal e prescrição de última circunspecção para o intérprete.

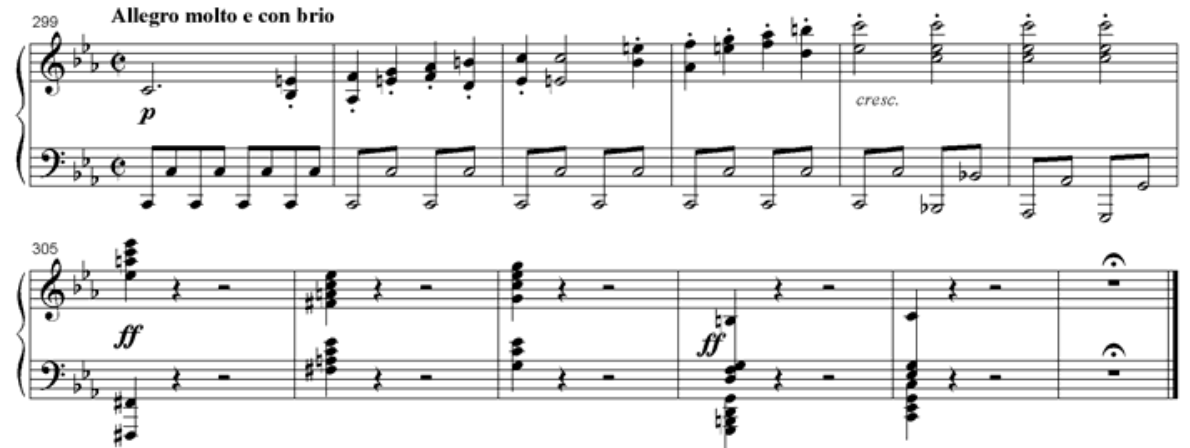

Figura 19 


\section{Conclusão}

O desenvolvimento da retórica na Antigüidade grega desenhou as linhas fundamentais de todo seu trajeto posterior. A necessidade da estruturação do discurso, de maneira a orientar uma eficaz e expressiva enunciação dos argumentos, alçou os oradores a um alto grau de coerência, no qual a lógica ocupava lugar de destaque. A corrente psicagógica complementou o espectro persuasivo que a retórica desejava abarcar, adicionando ao discurso a sedução irracional que a sábia utilização das palavras poderia acessar, e comungava preceitos originados no pitagorismo, no qual a função médico-mágica da música era admitida e admirada. Esta dupla natureza da retórica, lógica e algo mística, ecoava a divisão parmenídica entre o mundo da verdade e o mundo da doxa (opinião), também herança pitagórica.

A mais séria objeção dirigida à retórica foi a crítica platônica, de natureza moral, segundo a qual o parâmetro ético não seria devidamente atendido pelos preceitos retóricos e, portanto, esta alegada deficiência abriria caminho para a utilização deturpada dos conteúdos. A posição socrática e a perfeita e abrangente organização aristotélica julgaram haver superado tal objeção, embora seja admissível que a restrição platônica tenha servido à cristalização de um preconceito moral que atravessou os séculos. Deste preconceito, provavelmente, originam-se as conotações pejorativas que reiteradamente assolam o termo "retórica".

Em Aristóteles tivemos uma minuciosa exposição da disciplina retórica, com a construção dos entimemas (silogismos convincentes mas não irrefutáveis) amparando as divisões em gêneros, estes definidos por suas finalidades e devidamente expressos pelos diferentes estilos. Os lugares retóricos ou tópoi determinavam os argumentos adequados a cada gênero. O acréscimo das paixões, posteriormente realizado por Aristóteles, acolheu no seio da retórica as contribuições pitagóricas, unindo psicagogia e lógica num todo coerente, concluído com as divisões do discurso. E a abordagem aristotélica, por sua insuperável abrangência e profundidade, estaria fadada a transformar-se em paradigma de toda discussão que envolva a retórica, o que acabamos de confirmar em nosso presente estudo.

A retórica latina, cujas figuras de maior proeminência foram Cícero e Quintiliano, adaptou e renovou os conteúdos gregos, simultaneamente conservando suas linhas mestras. Com Cícero, conteúdo e forma apresentam-se interdependentes, e as 
palavras apenas permanecem imbuídas de beleza enquanto a serviço de nobres intenções, o que acaba por compor mais uma solução ao impasse platônico. Com Quintiliano, a organização das partes do discurso são reapresentadas em exposição clara e rica, conduzindo a tradição retórica Idade Média adentro.

Pelas septem artes liberales, música e retórica atravessaram toda a época medieval (tendo em Boecius um inigualável colaborador), adentrando o universo renascentista e barroco. Com a lenta emancipação da música da palavra no século XVIII, a autonomia da música instrumental exigiu que formas musicais específicas se erigissem, para abarcar o material musical em franco desenvolvimento.

Neste ponto, divisor de águas, situam-se os cruciais desafios que a retórica enfrentou e logrou superar.

Em primeira instância, permitir que uma semântica permanecesse veladamente atrelada à sintaxe musical, sem desautorizar a especificidade musical que essa sintaxe reclamava, mas subjazendo na ancestralidade psíquica que a ligação entre música e palavra houvera construído. Esta ancestralidade é simbólica e emocionalmente erigida, mas as origens dessa conjugação simbólica estão enraizadas em conceitos pitagóricos, traduzidos pela intrínseca dimensão ontológica da qual número e palavra são portadores, segundo reivindicamos.

Em segunda instância, e esta é a tese por nós defendida neste estudo, admitir que a retórica tenha alicerçado a emergência dos tipos formais musicais, pela aplicação da estrutura do processo de criação retórico à música (inventio, dispositio, elocutio, memoria e pronunciatio), e pela utilização de um modelo discursivo básico, apoiado nas divisões da dispositio (exordium, narratio, propositio, confutatio, confirmatio e conclusio).

Entretanto, a ascendência retórica das formas musicais não limita-se à aplicação das divisões acima expostas, mas também remete-se à análise das relações entre forma e conteúdo que norteiam toda nossa investigação. O paradoxo conceitual que envolve o termo “forma” tem como princípio nuclear tais relações.

As duas opostas acepções para o termo, forma como uma estrutura geral e recorrente que é comum a várias obras, e forma como a manifestação única de uma obra particular, apontam para as visões conformacional e generativa, conforme estudamos. No primeiro caso, delineia-se uma abordagem dos conteúdos de maneira a afirmar exclusivamente um protótipo formal já definido, com o risco iminente da deturpação dos conteúdos e conseqüente castração de suas possibilidades expressivas. No segundo 
caso, uma utilização desenfreada dos conteúdos acarreta uma inapetência dos mesmos no que se refere a gêneros, estilos e proporções harmônicas desejadas, subsidiando uma deformação da forma.

Nossa abordagem da forma sonata simultaneamente como um padrão formal recorrente e como uma escrita generativa, à maneira de um procedimento, aplicaram o paradoxo semântico a uma questão musical específica, sob a ótica do mais proeminente tipo formal. As abordagens analíticas reverberam esta cisão conceitual, ao conectarem de maneira algo rígida as sobreposições de um plano harmônico a um plano temático, o que logramos revelar e transpor a parâmetros mais maleáveis, mas nem por isso imprecisos. Também uma visão histórica da bipartição e tripartição da forma sonata oferece dados para a construção de uma imagem menos estanque do processo composicional e da análise formal, favorecendo a aceitação de conceitos em constante formação e transformação, que não são redutíveis a definições inertes, mas exigem a presença intrínseca do movimento que permeia toda criação artística, pois que humana.

A importância da gramática musical foi por nós sublinhada (não há discurso expressivo passível de ser exalado por meio de técnica claudicante), e a função da retórica junto a ela é estabelecer uma teia de conexões virtuosas, que seja capaz de transformar os elementos gramaticais em fluência discursiva. Tais conexões não podem ser obtidas apenas pelo crescente acúmulo de estruturas gramaticais, como motivos, frases e períodos, mas somente se forem dirigidas por uma função discursiva premeditada, nascida dos preceitos retóricos.

Em grande parte, é a melodia o fio de que é feita esta virtuosa teia de conexões, pois nela assenta-se prioritariamente (embora não exclusivamente) a capacidade da expressão dos afetos desejados. Os conceitos de tema e Hauptsatz corroboram esta função da melodia que, por sua "passionalidade” intrínseca, relaciona coerentemente uma forma abstrata ao gênero abordado.

A passagem da orientação pragmática para a expressiva, historicamente situada na primeira metade do século XIX, com a ascensão de uma prerrogativa individual a qualificar a atitude artística, retirou significativa importância do papel do ouvinte. Um dos pressupostos primordiais e fundamentais da retórica foi assim solapado, ainda que a inteligibilidade tenha sido preservada como parâmetro intocável. Disto resultou, como demonstramos, uma substituição da metáfora da oração pela metáfora do organismo, tida como mais apropriada para a descrição dos processos analíticos formais. No bojo desta alteração, sublinhando-a, desponta uma visão da obra exclusivamente a partir de 
seus próprios pressupostos, “ensimesmada” vale dizer. Ainda que a metáfora do organismo seja producente sob diversa ótica e até afim a alguns preceitos retóricos (portanto mantenedora de tais preceitos mesmo ante o declínio da retórica), retirou da obra de arte seu caráter de diálogo temporal (discursivo), sujeitando-a mais à contemplação estética, que pode, em alguns casos, traduzir-se por monólogo. Esfacelar ou apenas relativizar a função temporal da música é, sob determinado aspecto, reduzi-la. Enquanto arquitetura pode ser vislumbrada como arte que organiza o espaço, música pode ser a arte que organiza o tempo. Música é tempo audível ${ }^{51}$, poderíamos ousar dizer. E a forma musical se dá, indiscutivelmente, neste diálogo musical submetido ao tempo, organizado em nós por nossa própria memória.

A música, assim como a filosofia, acessa insistentemente uma região mais nobre da alma humana. E a nobreza se revela inteiramente apenas diante do que é igualmente nobre. Desperdiçar as mais excelentes energias que possuímos naquilo que não as absorve virtuosamente é que significa perder-se, é o verdadeiro sofisma. Proceder assim é ratificar a antipatia platônica para com a retórica. Em alguma medida sabemo-nos todos ignorantes, mas, curiosamente, quanto mais conscientes nos tornamos deste fato, proporcionalmente mais alimentamos nosso desejo de não deixarmos adormecer a nobreza que julgamos possuir.

\footnotetext{
${ }^{51}$ Ainda uma vez, formulação devida ao professor Ricardo Rizek.
} 


\section{Referências Bibliográficas}

ANDRADE, Mário de. Introdução à estética musical. São Paulo: Hucitec, 1995.

ARISTÓTELES. Arte retórica e arte poética. Trad. Antônio Pinto de Carvalho. Rio de Janeiro: Ediouro, s.d.

BAIRSTOW, EDWARD C, Sir. Evolution of musical form. London: Geoffrey Cumberlege, 1949.

BARROS, Cassiano de Almeida. A orientação retórica no processo de composição do classicismo observada a partir do tratado Versuch einer Anleitung zur Composition (1782-1793) de H. C. Koch. Campinas, 2006. Dissertação (Mestrado) - Instituto de Artes, Universidade Estadual de Campinas.

BARRY, Barbara R. The philosopher's stone: essays in the transformation of musical structure. Hillsdale, NY: Pendragon Press, 2000. (Pebdragon Press series en musicology (viii)).

BARTEL, Dietrich. Musica Poetica: musical rhetorical figures in German Baroque music. Nebraska: University of Nebraska Press, 1997.

BAS, Giulio. Trattato di forma musicale. Milano: Ricordi, 1964.

BLOCH, Ernst. Essays on philosophy of music. Cambridge: Cambridge University Press, 1991.

BONDS, Mark Evan. Wordless rhetoric: musical form and the metaphor of the oration. Cambridge, Massachussetts and London: Harvard University Press, 1991.

COKER, Wilson. Music \& meaning: a theoretical introduction to musical aesthetics. New York: Free Press, 1972.

CONE, Edward T. Musical form and musical performance. New York: W. W. Norton, 1968.

DAHLHAUS, Carl. Estética Musical. Trad. Artur Morão. Lisboa: Ed. 70, 1991.

HOUAISS, Antônio; VILLAR, Mauro de Salles. Dicionário Houaiss da língua portuguesa. Rio de Janeiro: Objetiva, 2001.

KELLER, Hermann. Phrasing and Articulation: a contribution to a rhetoric of music. New York: Norton Library, 1973.

KIEFER, Bruno. História e significado das formas musicais. Porto Alegre: Movimento, 1976. 
KLEIN, Robert. A Forma e o Inteligível: escritos sobre o Renascimento e a arte moderna. Trad. Cely Arena. São Paulo: Edusp, 1998.

LUCAS, Mônica Isabel. Humor e Agudeza nos Quartetos de Cordas op. 33 de Joseph Haydn. Campinas, 2005. Tese (Doutorado) - Instituto de Artes, Universidade Estadual de Campinas.

MANN, Alfred. The Study of Fugue. New York: Dover Publications, 1987.

MERSIOVSKY, Gertrud. Organo pleno e retórica musical nos prelúdios e fugas de Johann Sebastian Bach. Rio de Janeiro: Dois Passos, 2005.

NEUBAUER, John. The emancipation of music from language: departure from mimesis in eighteenth-century aesthetics. New Haven: Yale University Press, 1986.

NUNES, Benedito. Introdução à filosofia da arte. São Paulo: Desa, 1966.

OSBORNE, Harold. Estética e teoria da arte: uma introdução histórica. Trad. Octavio Mendes Cajado. São Paulo: Cultrix, 1974.

PIANA, Giovanni. A filosofia da música. Trad. Antonio Angonese. Bauru: Edusc, 2001.

PLATÃO. Apologia de Sócrates. Trad. Maria Lacerda de Moura. Rio de Janeiro: Ediouro, s.d. [a].

Pensadores).

A República. Trad. Enrico Corvisieri. São Paulo: Nova Cultural, 1997. (Os . Diálogos: Mênon-Banquete-Fedro. Trad. Jorge Paleikat. Rio de Janeiro: Ediouro, s.d. [b].

PLEBE, Armando. Breve história da retórica antiga. Trad. Gilda Naécia Maciel de Barros. São Paulo: Edusp, 1978.

RATNER, Leonard G. Classic Music. New York: Schirmer Books, 1980.

RIEMANN, Hugo. Composición musical: teoria de las formas musicales. 2. ed. Barcelona: Labor, 1943.

RIZEK, Ricardo. A teoria da harmonia em Platão: um estudo sobre a identidade da música ocidental. São Paulo, 2003. Dissertação (Mestrado em Musicologia) - Escola de Comunicações e Artes, Universidade de São Paulo.

RODRIGUES, André Figueiredo. Como elaborar citações e notas de rodapé. $3^{\mathrm{a}}$ ed. amp. São Paulo: Humanitas/FFLCH/USP, 2005. (Metodologias, v. 2)

Humanitas/FFLCH/USP, 2004. 
ROSEN, Charles. Formas de sonata. Trad. Luis Romano Haces. Barcelona: Editorial Labor, 1987.

SANTOS, Mário Ferreira dos. Pitágoras e o tema do número. São Paulo: Ibrasa, 2000.

SCHOENBERG, Arnold. Fundamentos da Composição Musical. Trad. Eduardo Seincman. São Paulo: Edusp, 1991. Harmonia. Trad. Marden Maluf. São Paulo: Ed. da Unesp, 1999.

SEINCMAN, Eduardo. Do fenômeno musical. São Paulo, 1996. Dissertação (Livredocência), - Escola de Comunicações e Artes, Universidade de São Paulo.

Do tempo musical. São Paulo: Via Lettera, FAPESP, 2001.

TOMÁS, Lia. Ouvir o lógos: música e filosofia. São Paulo: Editora Unesp, 2002.

VIDAL, João Vicente. A idéia do 'clássico' no classicismo. Rio de Janeiro, 2002. Dissertação (Mestrado em Musicologia) - Escola de Música do Centro de Letras e Artes, Universidade Federal do Rio de Janeiro.

WISNIK, José Miguel. O som e o sentido: uma outra história das músicas. São Paulo: Companhia das Letras, 1989.

ZAMACOIS, Joaquin. Curso de Formas Musicales. 4. ed. Barcelona: Labor, 1979.

ZUCKERKANDL, Victor. Sense of Music. Princeton: Princeton University, 1971.

\section{Partitura}

BEETHOVEN, Ludwig van. Klaviersonaten (Band 1). München: G. Henle Verlag, 1952/1980. Sonate n 8, opus 13 - “Grande Sonate Pathétique”. Piano. 


\section{Anexo}

Partitura do primeiro movimento da Sonata n 8, opus 13 - "Patética" L. V. Beethoven.

\section{SONATE}

grande sonate pathétique - op.13

Dem Fürsten Carl von Lichnowsky gewidmet komponiert 1798/99

L. van Beethoven
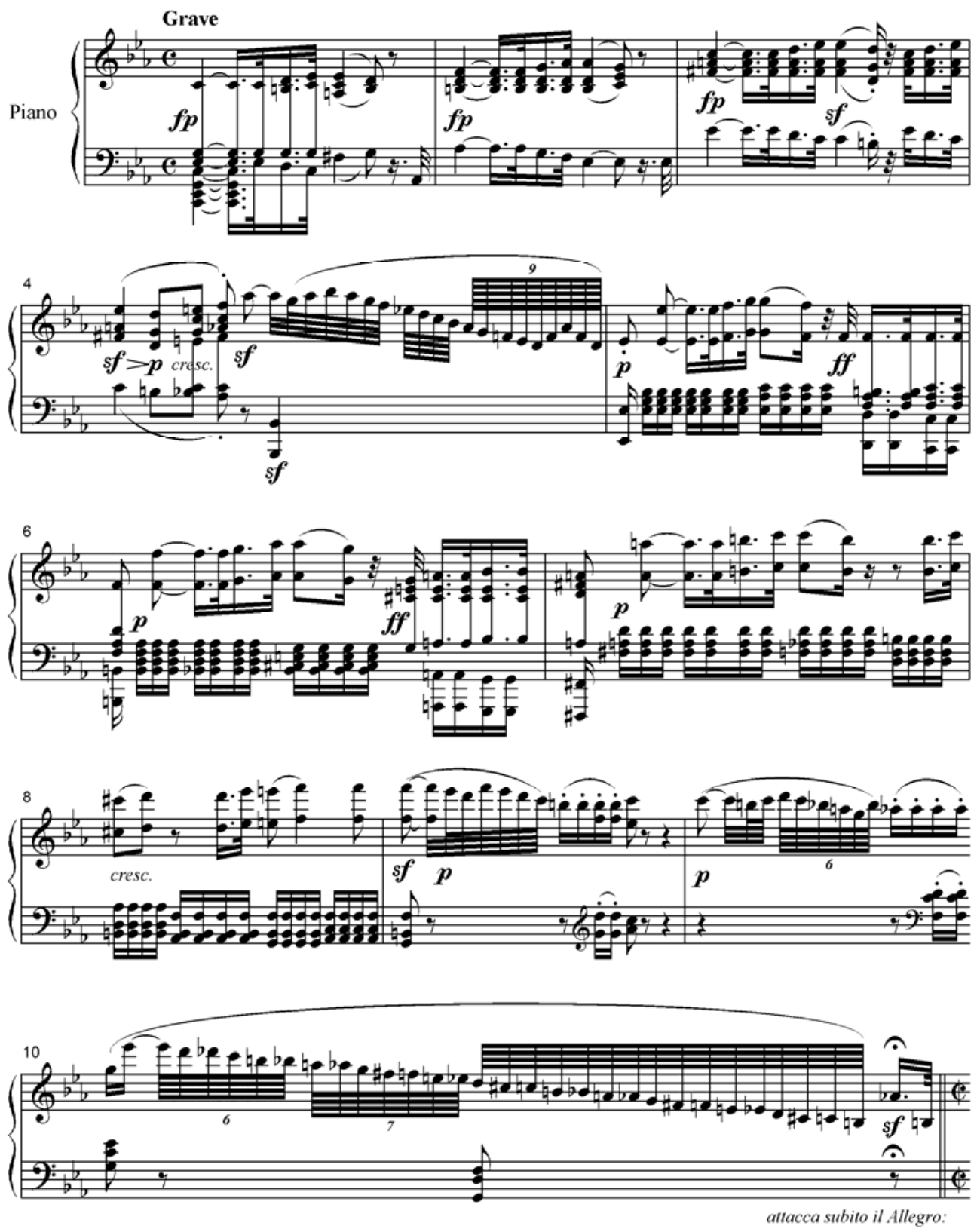

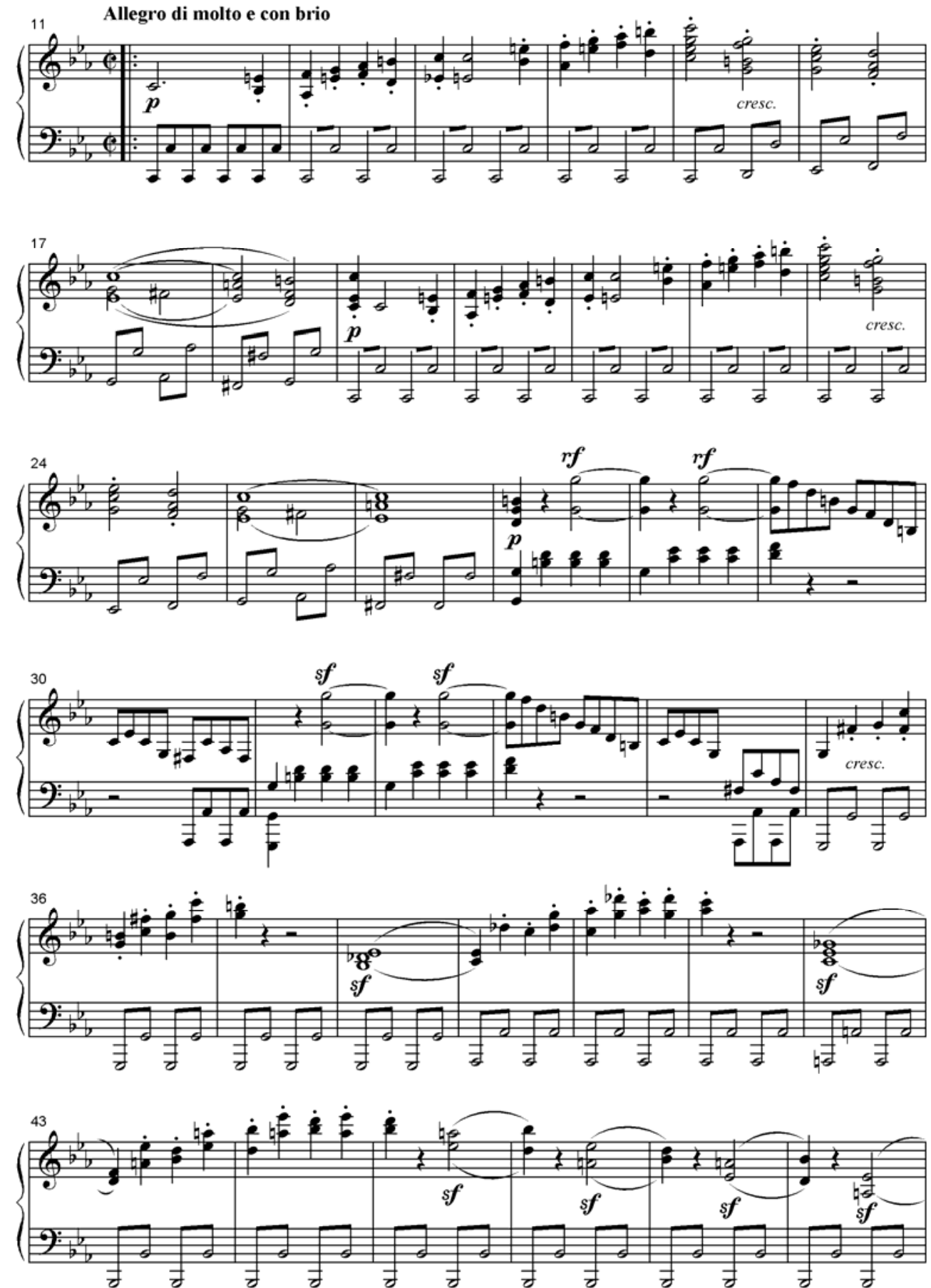

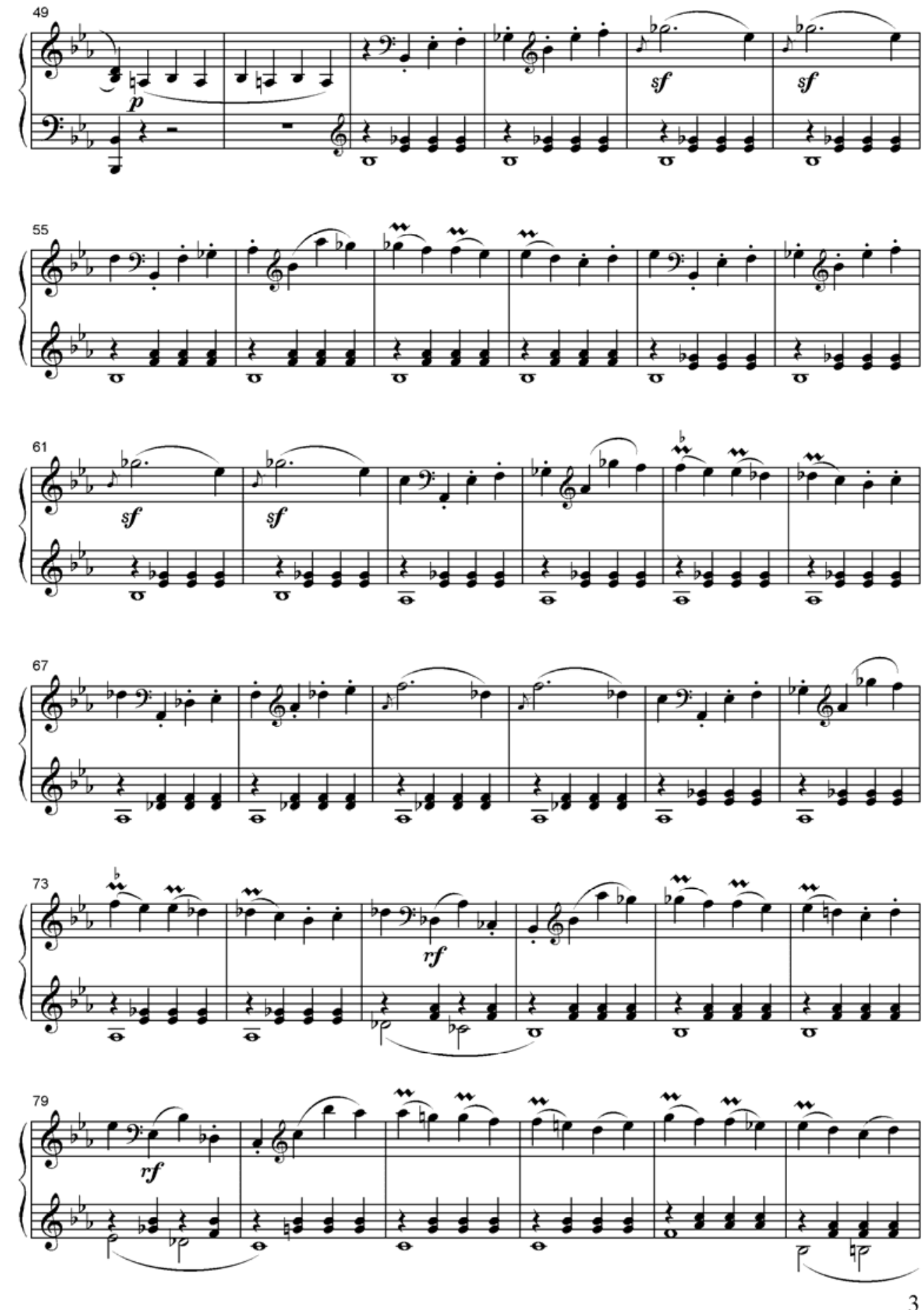

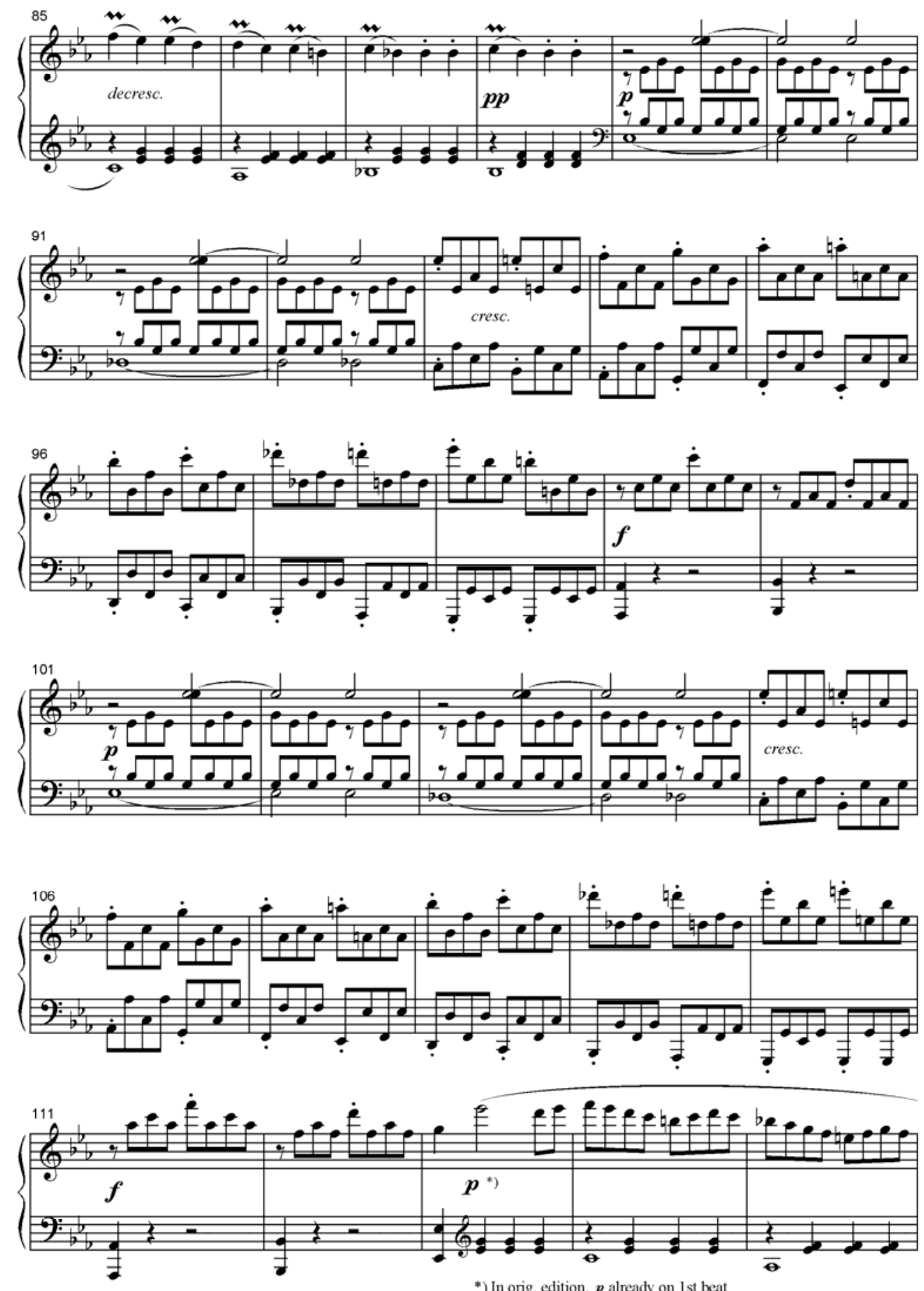

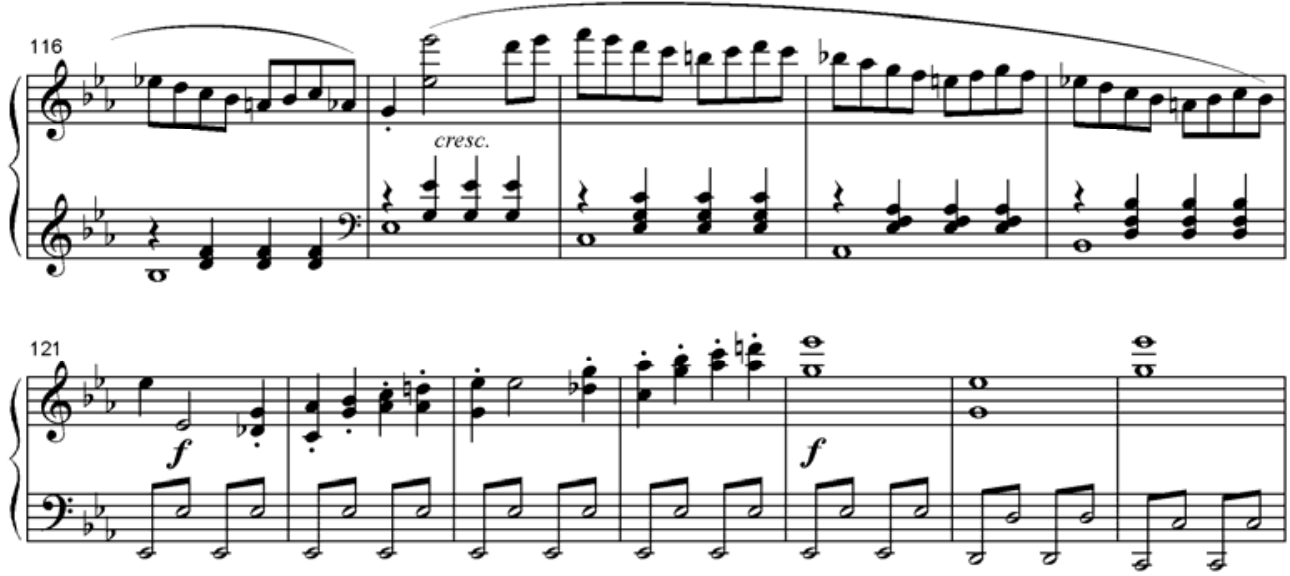

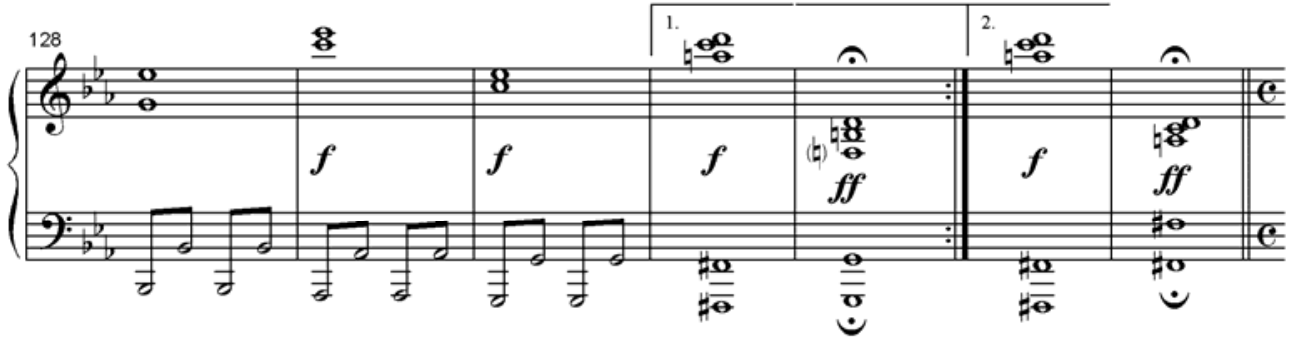
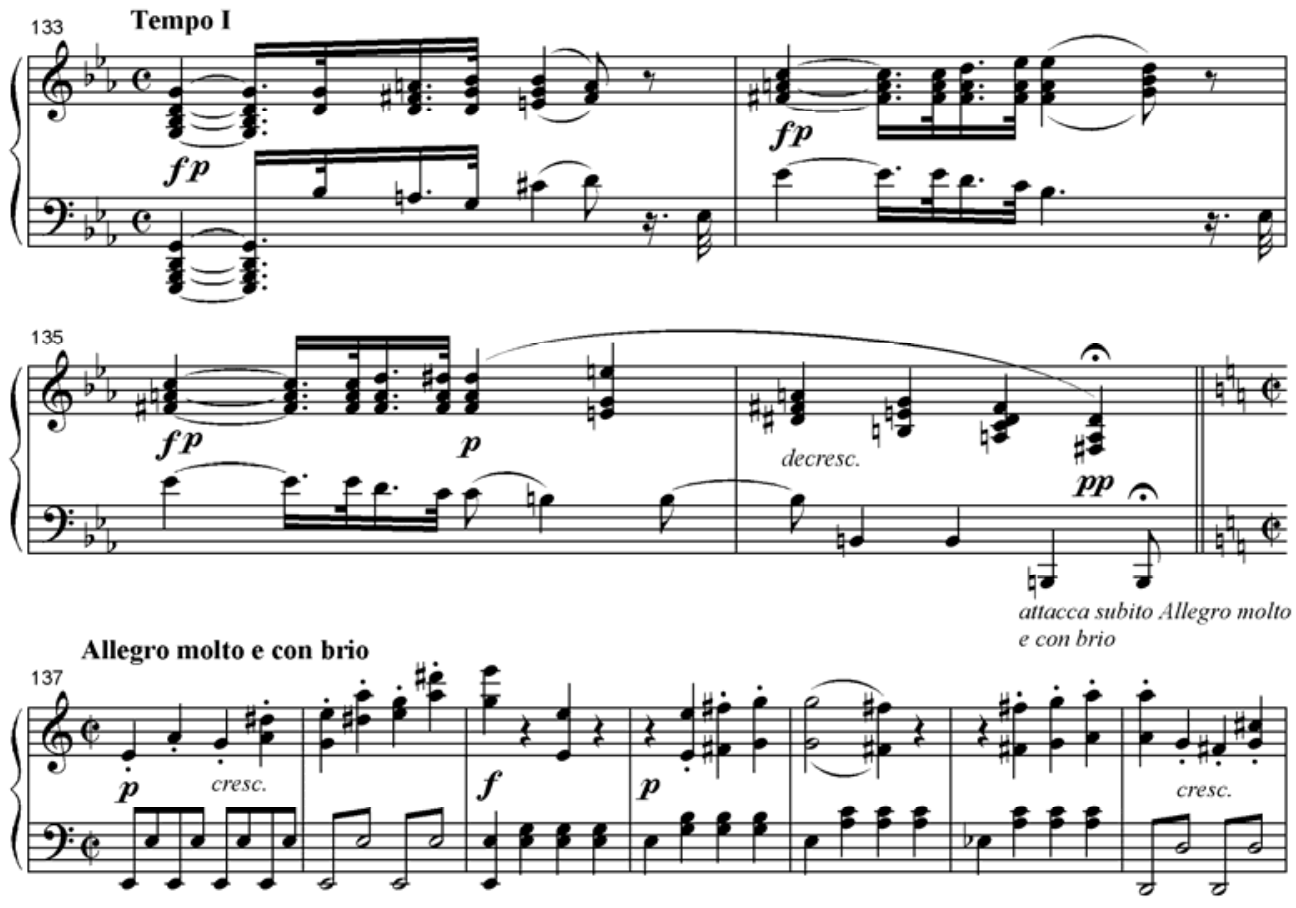

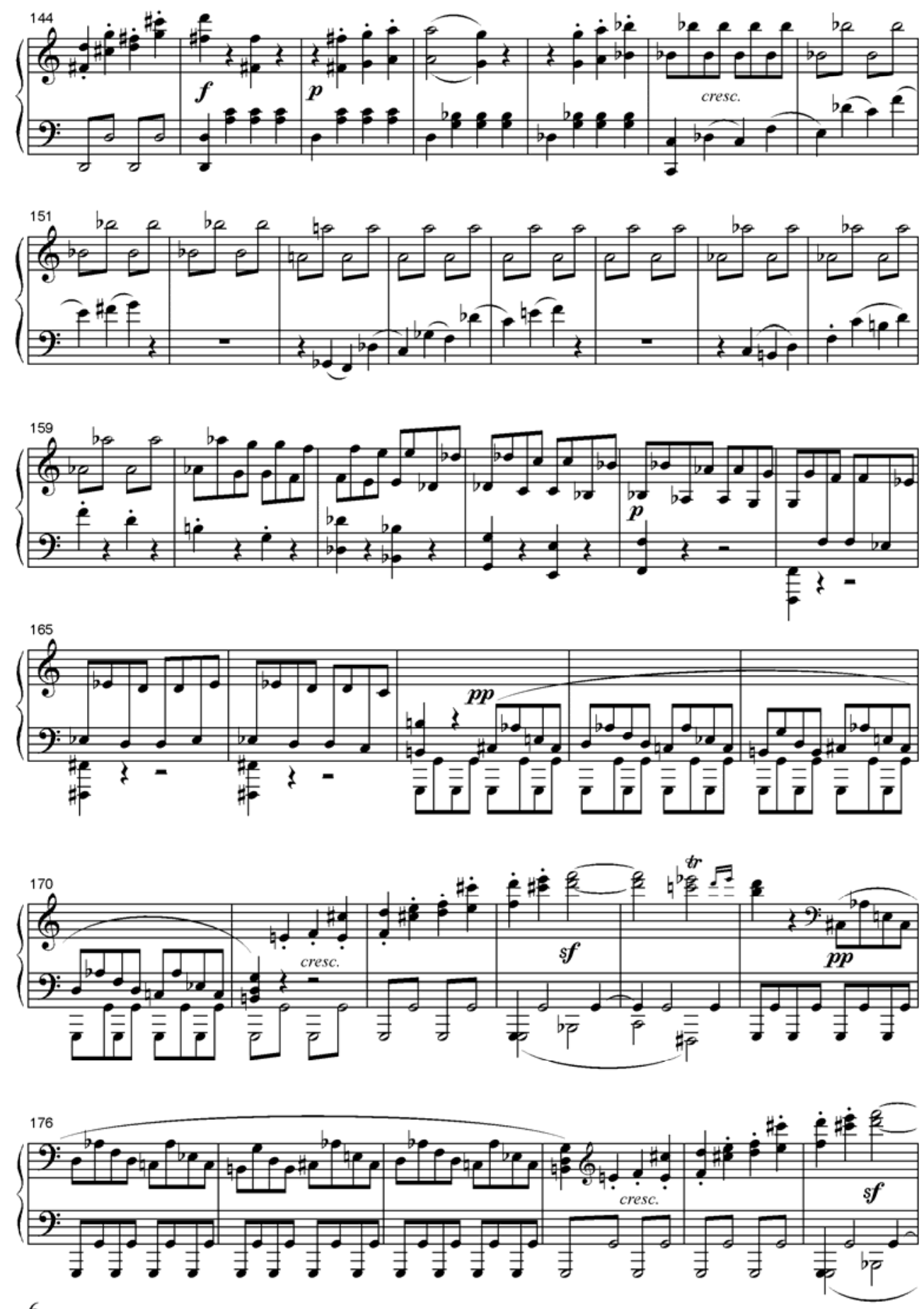

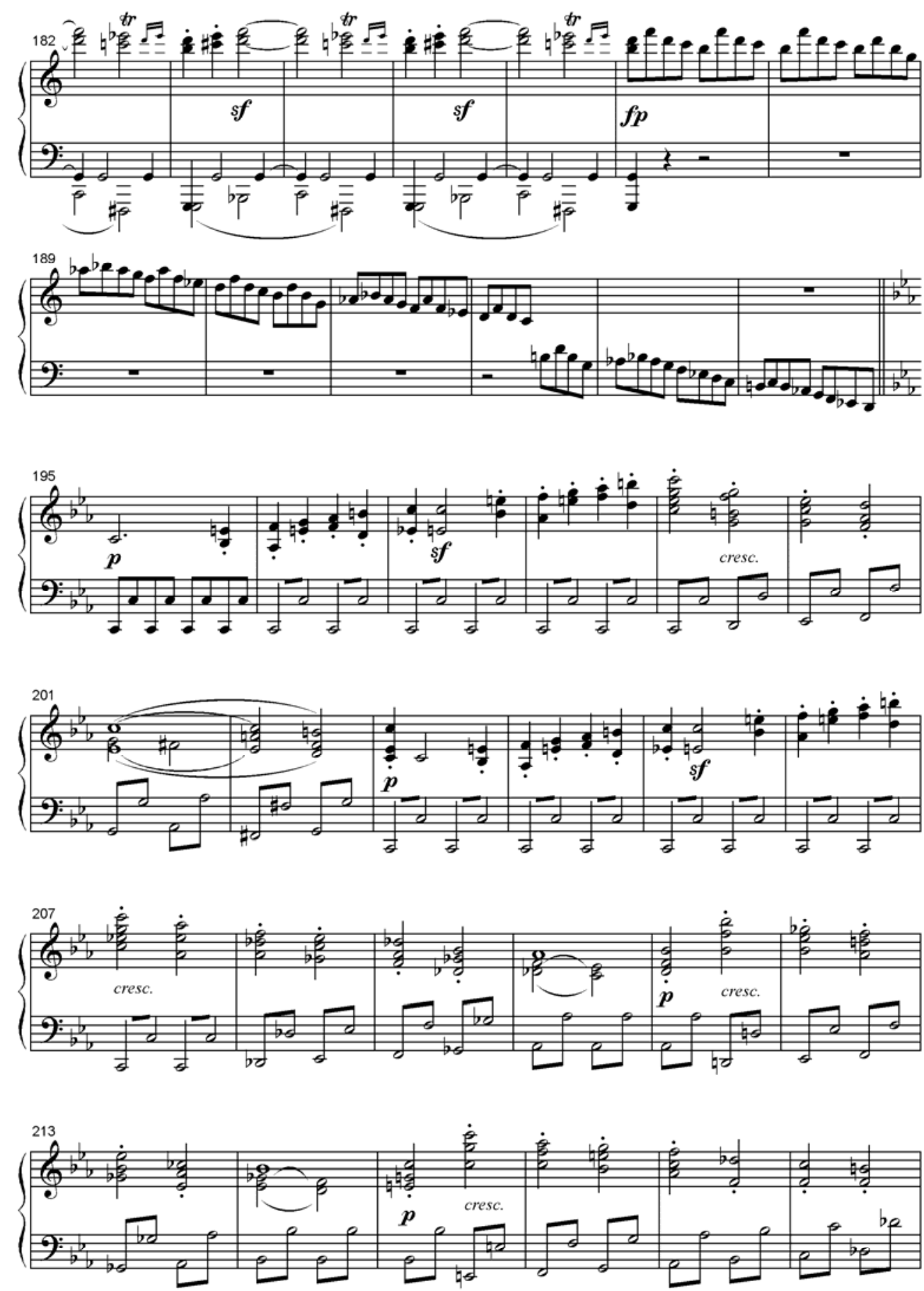

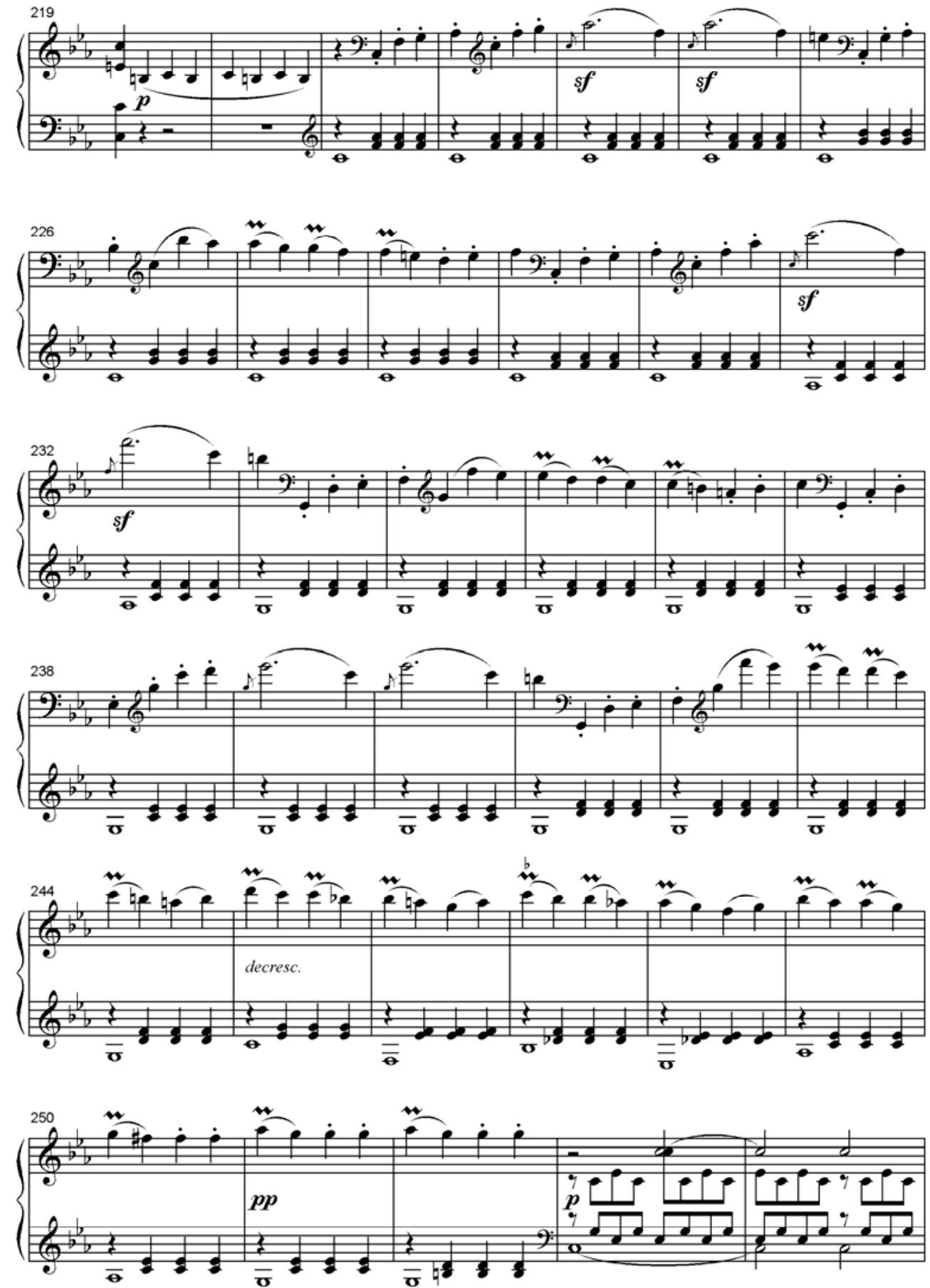

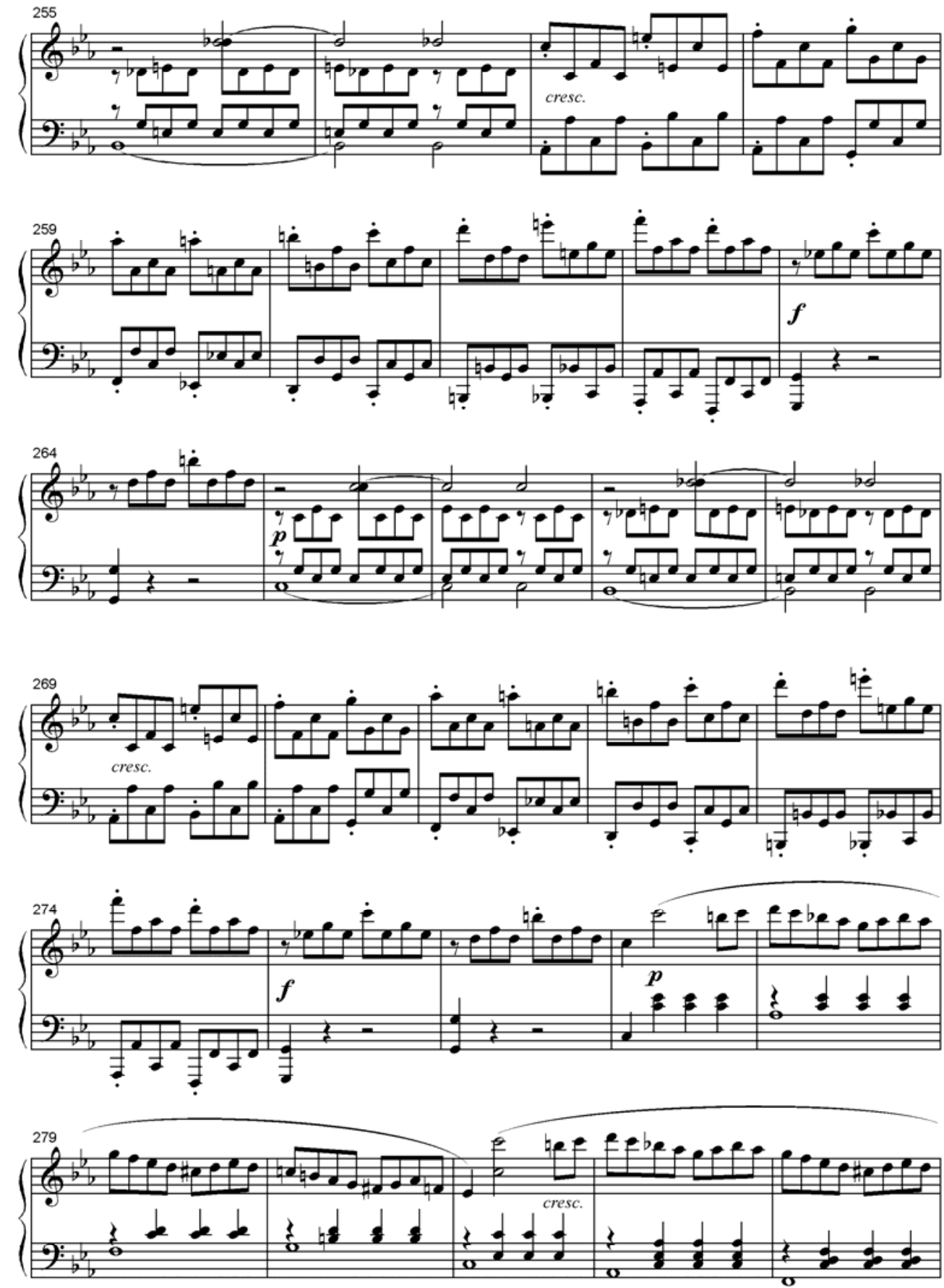

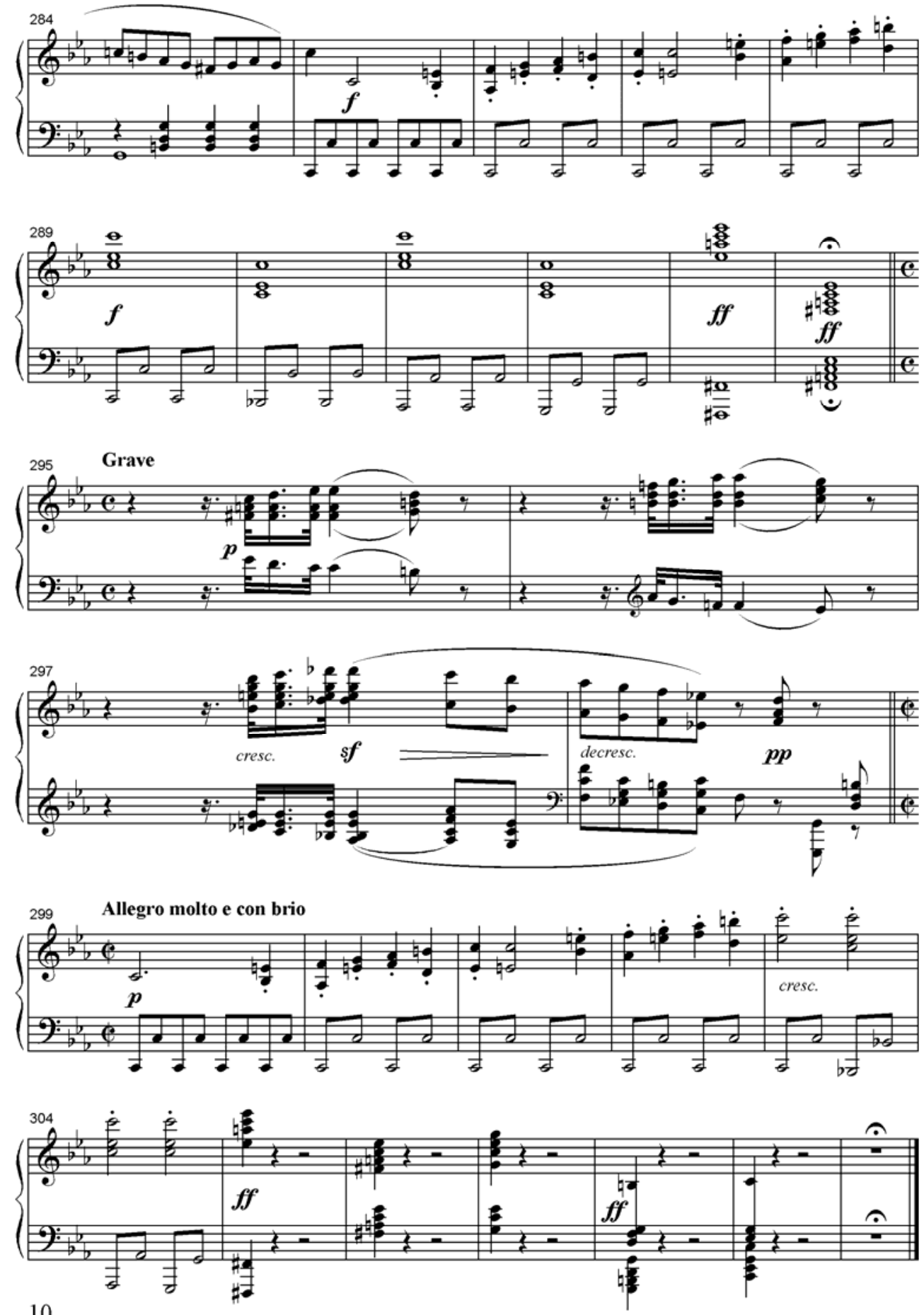